Utah State University

DigitalCommons@USU

\title{
$5-2015$
}

\section{Effects of Environmental Water Transfers on Stream Temperatures}

Logan Elmore

Utah State University

Follow this and additional works at: https://digitalcommons.usu.edu/etd

Part of the Life Sciences Commons

\section{Recommended Citation}

Elmore, Logan, "Effects of Environmental Water Transfers on Stream Temperatures" (2015). All Graduate Theses and Dissertations. 4368.

https://digitalcommons.usu.edu/etd/4368

This Thesis is brought to you for free and open access by the Graduate Studies at DigitalCommons@USU. It has been accepted for inclusion in All Graduate Theses and Dissertations by an authorized administrator of DigitalCommons@USU. For more information, please contact digitalcommons@usu.edu.

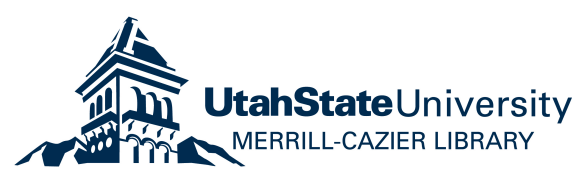


Copyright (C) Logan Elmore 2015

All Rights Reserved 


\author{
ABSTRACT \\ by \\ Logan Elmore, Master of Science \\ Utah State University, 2015
}

Effects of Environmental Water Transfers on Stream Temperatures

\begin{abstract}
Major Professor: Dr. Sarah Null
Department: Watershed Sciences
\end{abstract}

Low streamflows and warm stream temperatures, caused mainly from agricultural diversions, currently limit available habitat and productivity of trout, including native Lahontan cutthroat trout in Nevada's Walker River Basin. Environmental water purchases, which reallocate water from willing sellers to instream uses, are being evaluated to improve instream habitat. To test the efficacy of existing and potential environmental water transfers, this study uses River Modeling System version 4 (RMS4) to develop a stream temperature model to simulate environmental water transfer effects on stream temperature. Model runs simulate a range of environmental water transfers, from of $0.14 \mathrm{cms}$ to $1.41 \mathrm{cms}$, at diversions and reservoirs. Results indicate that low flows generally coincide with critically warm stream temperatures, thermal refugia exist on the East Walker River, a tributary of the Walker River, environmental water transfers can improve stream temperature for some highly impacted reaches by up to $3^{\circ} \mathrm{C}$ in dry years, and environmental water transfers have a greater effect in dry years than wet years. 


\section{PUBLIC ABSTRACT}

Effects of Environmental Water Transfers on Stream Temperatures

by

Logan Elmore, Master of Science

Utah State University, 2015

Major Professor: Dr. Sarah Null
Department: Watershed Sciences

Low streamflows and warm stream temperatures, caused mainly from agricultural diversions, currently limit available habitat and productivity of trout, including native Lahontan cutthroat trout in Nevada's Walker River Basin. Environmental water purchases, which transfer water from willing sellers to instream uses (i.e for fish), are being evaluated to improve instream habitat. To determine which environmental water purchases to prioritize, this study was undertaken to build a computer model in order to simulate stream temperatures under differing environmental water transfer scenarios. Model runs simulate a range of environmental water transfers at major diversions and reservoirs throughout the Walker River Basin. Results indicate that low flows generally coincide with critically warm stream temperatures, cooler stream temperatures exist in the East Walker River, a tributary of the Walker River, during warm seasons which provide good habitat for fish, environmental transfers can improve stream temperatures for some highly impacted reaches by up to $3^{\circ} \mathrm{C}$ in dry years, and environmental water transfers have a greater effect in dry years than wet years. 


\section{ACKNOWLEDGMENTS}

I would like to thank the National Fish and Wildlife Foundation for providing the funding that made this intellectually gratifying project possible. I would also like to thank my advisor, Dr. Sarah Null, for having faith enough to involve me in this project. I will be forever grateful for all of the guidance she provided me, which will help me throughout my life and career. I am very grateful for the wise input provided from my committee members, Dr. Beth Neilson and Dr. Brett Roper. Many thanks should be given to my lab mates in the ACWA Lab: Nate Mouzon, James White, Dave Betts, Connor Prenrod, and Tim Beach. Their thoughtful and insightful advice was always appreciated and provided a base of camaraderie that made being a part of the lab great. Special thanks should go to Nate Mouzon, whose friendship and contribution to the Walker Basin research greatly assisted my own work. I am thankful for Curtis Gray, who provided much needed company and advice for an incoming southern graduate student far from home. I must also acknowledge the incredibly helpful and encouraging Department of Watershed Sciences administration staff, Brian Bailey and Enid Kelly, who always went above and beyond to provide invaluable assistance. Finally, I would especially like to thank my wife, Sara, for sticking by my side and providing persistent encouragement during the trying times of graduate school. She always lifted my spirits, and still does.

Logan Elmore 


\section{CONTENTS}

Page

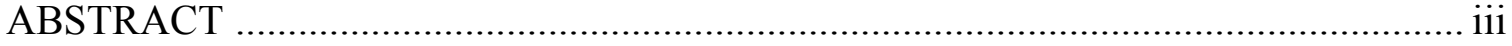

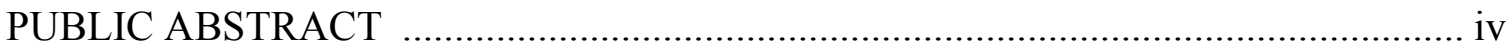

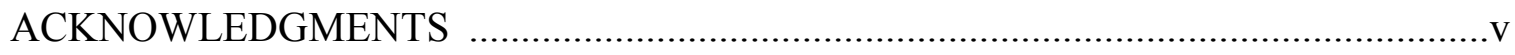

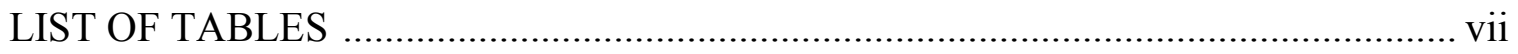

LIST OF FIGURES ................................................................................... viii

CHAPTER

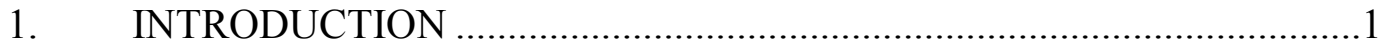

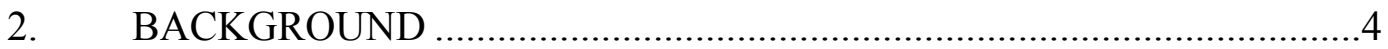

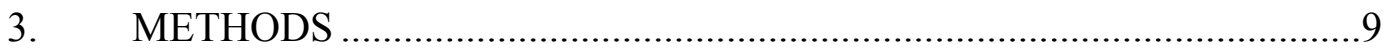

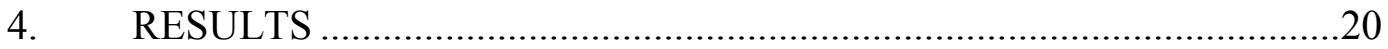

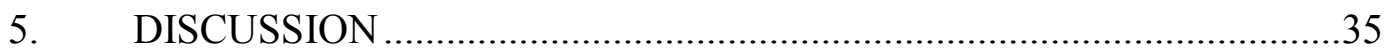

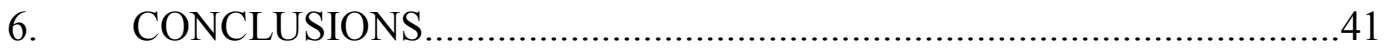

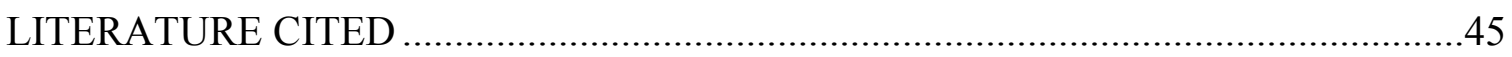

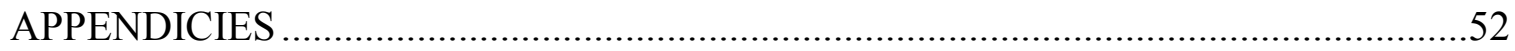

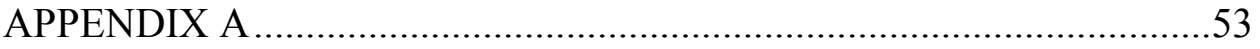

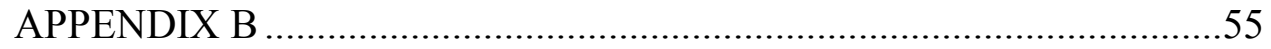




\section{LIST OF TABLES}

Table

3-1. Input data types, sources, collection periods, and collection sites........................12

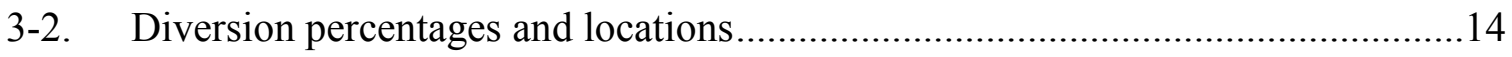

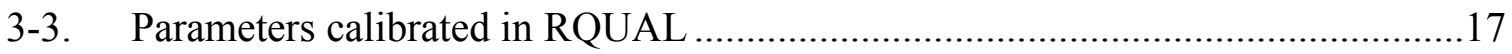

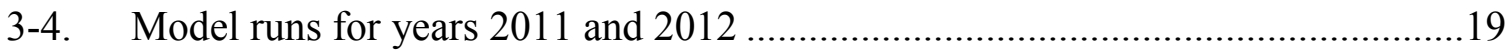

4-1. Measured versus modeled 2011 and 2012 streamflow statistics .........................22

4-2. Measured versus modeled 2011 and 2012 stream temperature statistics .............25

4-3. Seven day average and maximum daily stream temperatures for summer weeks with Historical Conditions at selected river kilometers ......................................26

4-4. Maximum change in 7 day average (chronic) and daily maximum (acute) stream temperatures by model run for 2011 and 2012 from July 1 - August 26..............32

4-5. Total irrigation season water not diverted by model run in cms..........................33 


\section{LIST OF FIGURES}

Figure

2-1. Walker River and tributaries with USGS discharge gages, stream temperature logger locations, and Smith Valley meteorological station

2-2. Measured hourly stream temperatures from 20 iButton temperature loggers distributed throughout the Walker Basin

2-3. Measured 7 day average stream temperatures from 20 iButton temperature loggers distributed throughout the Walker Basin

2-4. Historical LCT distribution and current estimated range outlined in red (adapted from Dunham et al. 1999)

3-1. Schematic of 5 point river cross-sections 11

3-2. LiDAR image of the Walker River near Mason Valley Wildlife Refuge with buffer lines and center line elevation points

3-3. Major inflows, outflows, and accretion/depletion reaches for the Walker River and its tributaries

4-1. Measured and modeled hourly streamflow for irrigation season 2011 at river $\mathrm{km}$ 94.02.

4-2. Measured and modeled hourly streamflow for irrigation season 2012 at river $\mathrm{km}$ 24.02 .

4-3. Measured and modeled hourly stream temperatures for irrigation season 2011 at river $\mathrm{km} 94.02$

4-4. Measured and modeled hourly stream temperatures for irrigation season 2012 at river $\mathrm{km} 94.02$

4-5. Modeled daily maximum stream temperature longitudinal profile on 8/2/2011 for Historical conditions (solid line) and Existing Transfers (dashed line). 
4-6. Modeled daily maximum stream temperature longitudinal profile on 8/2/2012 for Historical Conditions (solid line) and Existing Transfers (dashed line)

4-7. Hourly stream temperatures at river $\mathrm{km} 2.69$ for week $7 / 22 / 2011 \ldots \ldots \ldots \ldots \ldots \ldots \ldots . . . . . . . .30$

4-8. Hourly stream temperatures at river $\mathrm{km} 2.69$ for week $7 / 22 / 2012$.......................31

5-1. Probability of exceedance for daily maximum stream temperatures during irrigation season 2012 ( $\mathrm{n}=245$ days) at river $\mathrm{km} 2.69$

5-2. Measured average daily reservoir release temperatures from Bridgeport and Topaz Reservoirs

5-3. Number of days in 2012 that stream temperature exceeded $28^{\circ} \mathrm{C}$ for all reaches in selected model runs.

5-4. River length that maximum daily stream temperatures exceeded $28^{\circ} \mathrm{C}$ for all reaches in selected model runs during the hottest week in 2012.

B-1. Measured versus modeled stream temperatures at RKM 2.69 near the mouth of Walker Lake

B-2. Historical conditions versus existing transfers stream temperatures at RKM 2.69 near the mouth of Walker Lake

B-3. Existing transfers versus $0.14 \mathrm{cms}$ transfers from Bridgeport Reservoir stream temperatures at RKM 2.69 near the mouth of Walker Lake

B-4. Existing transfers versus $0.14 \mathrm{cms}$ transfers from BNGHH diversion stream temperatures at RKM 2.69 near the mouth of Walker Lake

B-5. Existing transfers versus $0.14 \mathrm{cms}$ transfers from FOX diversion stream temperatures at RKM 2.69 near the mouth of Walker Lake

B-6. Existing transfers versus $0.14 \mathrm{cms}$ transfers from MCCAMP diversion stream temperatures at RKM 2.69 near the mouth of Walker Lake

B-7. Existing transfers versus $0.14 \mathrm{cms}$ transfers from SSWJD diversion stream temperatures at RKM 2.69 near the mouth of Walker Lake 
B-8. Existing transfers versus $0.14 \mathrm{cms}$ transfers from CANAL diversion stream temperatures at RKM 2.69 near the mouth of Walker Lake.

B-9. Existing transfers versus $0.14 \mathrm{cms}$ transfers from SARONI diversion stream temperatures at RKM 2.69 near the mouth of Walker Lake

B-10. Existing transfers versus $0.14 \mathrm{cms}$ transfers from GAGE diversion stream temperatures at RKM 2.69 near the mouth of Walker Lake

B-11. Existing transfers versus $0.14 \mathrm{cms}$ transfers from COLONY diversion stream temperatures at RKM 2.69 near the mouth of Walker Lake

B-12. Existing transfers versus $0.14 \mathrm{cms}$ transfers from TUNNEL diversion stream temperatures at RKM 2.69 near the mouth of Walker Lake

B-13. Existing transfers versus $0.28 \mathrm{cms}$ transfers from Bridgeport Reservoir stream temperatures at RKM 2.69 near the mouth of Walker Lake

B-14. Existing transfers versus $0.28 \mathrm{cms}$ transfers from BNGHH diversion stream temperatures at RKM 2.69 near the mouth of Walker Lake

B-15. Existing transfers versus $0.28 \mathrm{cms}$ transfers from FOX diversion stream temperatures at RKM 2.69 near the mouth of Walker Lake

B-16. Existing transfers versus $0.28 \mathrm{cms}$ transfers from MCCAMP diversion stream temperatures at RKM 2.69 near the mouth of Walker Lake

B-17. Existing transfers versus $0.28 \mathrm{cms}$ transfers from SSWJD diversion stream temperatures at RKM 2.69 near the mouth of Walker Lake

B-18. Existing transfers versus $0.28 \mathrm{cms}$ transfers from CANAL diversion stream temperatures at RKM 2.69 near the mouth of Walker Lake

B-19. Existing transfers versus $0.28 \mathrm{cms}$ transfers from SARONI diversion stream temperatures at RKM 2.69 near the mouth of Walker Lake

B-20. Existing transfers versus $0.28 \mathrm{cms}$ transfers from GAGE diversion stream temperatures at RKM 2.69 near the mouth of Walker Lake 
B-21. Existing transfers versus $0.28 \mathrm{cms}$ transfers from COLONY diversion stream temperatures at RKM 2.69 near the mouth of Walker Lake

B-22. Existing transfers versus $0.28 \mathrm{cms}$ transfers from TUNNEL diversion stream temperatures at RKM 2.69 near the mouth of Walker Lake .66

B-23. Existing transfers versus $0.71 \mathrm{cms}$ transfers from Bridgeport Reservoir stream temperatures at RKM 2.69 near the mouth of Walker Lake

B-24. Existing transfers versus $0.71 \mathrm{cms}$ transfers from Topaz Reservoir stream temperatures at RKM 2.69 near the mouth of Walker Lake

B-25. Existing transfers versus $0.71 \mathrm{cms}$ transfers from SSWJD diversion stream temperatures at RKM 2.69 near the mouth of Walker Lake

B-26. Existing transfers versus $1.41 \mathrm{cms}$ transfers from Bridgeport Reservoir stream temperatures at RKM 2.69 near the mouth of Walker Lake

B-27. Existing transfers versus $1.41 \mathrm{cms}$ transfers from Topaz Reservoir stream temperatures at RKM 2.69 near the mouth of Walker Lake

B-28. Existing transfers versus $1.41 \mathrm{cms}$ transfers from SSWJD diversion stream temperatures at RKM 2.69 near the mouth of Walker Lake

B-29. Existing transfers versus zero diversions from BNGHH diversion stream temperatures at RKM 2.69 near the mouth of Walker Lake .70

B-30. Existing transfers versus zero diversions from FOX diversion stream temperatures at RKM 2.69 near the mouth of Walker Lake .70

B-31. Existing transfers versus zero diversions from MCCAMP diversion stream temperatures at RKM 2.69 near the mouth of Walker Lake

B-32. Existing transfers versus zero diversions from SSWJD diversion stream temperatures at RKM 2.69 near the mouth of Walker Lake .71

B-33. Existing transfers versus zero diversions from CANAL diversion stream temperatures at RKM 2.69 near the mouth of Walker Lake 
B-34. Existing transfers versus zero diversions from SARONI diversion stream temperatures at RKM 2.69 near the mouth of Walker Lake

B-35. Existing transfers versus zero diversions from GAGE diversion stream temperatures at RKM 2.69 near the mouth of Walker Lake

B-36. Existing transfers versus zero diversions from COLONY diversion stream temperatures at RKM 2.69 near the mouth of Walker Lake

B-37. Existing transfers versus zero diversions from TUNNEL diversion stream temperatures at RKM 2.69 near the mouth of Walker Lake

B-38. Existing transfers versus no diversions from all diversions (combined) stream temperatures at RKM 2.69 near the mouth of Walker Lake

B-39. Sensitivity analysis of Existing transfers with $0.94 \mathrm{~m}$ depth versus Existing transfers with $1.18 \mathrm{~m}$ depth (20\% increase) stream temperatures at RKM 2.69 near the mouth of Walker Lake

B-40. Sensitivity analysis of Existing transfers scenario versus Existing transfers with full shade stream temperatures at RKM 2.69 near the mouth of Walker Lake .....75

B-41. Measured versus modeled stream temperatures at RKM 2.69 near the mouth of Walker Lake

B-42 . Historical Conditions versus existing transfers stream temperatures at RKM 2.69 near the mouth of Walker Lake .76

B-43. Existing transfers versus $0.14 \mathrm{cms}$ transfers from Bridgeport Reservoir stream temperatures at RKM 2.69 near the mouth of Walker Lake....

B-44. Existing transfers versus $0.14 \mathrm{cms}$ transfers from BNGHH diversion stream temperatures at RKM 2.69 near the mouth of Walker Lake

B-45. Existing transfers versus $0.14 \mathrm{cms}$ transfers from FOX diversion stream temperatures at RKM 2.69 near the mouth of Walker Lake....

B-46. Existing transfers versus $0.14 \mathrm{cms}$ transfers from MCCAMP diversion stream temperatures at RKM 2.69 near the mouth of Walker Lake 
B-47. Existing transfers versus $0.14 \mathrm{cms}$ transfers from SSWJD diversion stream temperatures at RKM 2.69 near the mouth of Walker Lake.

B-48. Existing transfers versus $0.14 \mathrm{cms}$ transfers from CANAL diversion stream temperatures at RKM 2.69 near the mouth of Walker Lake

B-49. Existing transfers versus $0.14 \mathrm{cms}$ transfers from SARONI diversion stream temperatures at RKM 2.69 near the mouth of Walker Lake

B-50. Existing transfers versus $0.14 \mathrm{cms}$ transfers from GAGE diversion stream temperatures at RKM 2.69 near the mouth of Walker Lake

B-51. Existing transfers versus $0.14 \mathrm{cms}$ transfers from COLONY diversion stream temperatures at RKM 2.69 near the mouth of Walker Lake

B-52. Existing transfers versus $0.14 \mathrm{cms}$ transfers from TUNNEL diversion stream temperatures at RKM 2.69 near the mouth of Walker Lake

B-53. Existing transfers versus $0.28 \mathrm{cms}$ transfers from Bridgeport Reservoir stream temperatures at RKM 2.69 near the mouth of Walker Lake

B-54. Existing transfers versus $0.28 \mathrm{cms}$ transfers from BNGHH diversion stream temperatures at RKM 2.69 near the mouth of Walker Lake

B-55. Existing transfers versus $0.28 \mathrm{cms}$ transfers from FOX diversion stream temperatures at RKM 2.69 near the mouth of Walker Lake

B-56. Existing transfers versus $0.28 \mathrm{cms}$ transfers from MCCAMP diversion stream temperatures at RKM 2.69 near the mouth of Walker Lake

B-57. Existing transfers versus $0.28 \mathrm{cms}$ transfers from SSWJD diversion stream temperatures at RKM 2.69 near the mouth of Walker Lake

B-58. Existing transfers versus $0.28 \mathrm{cms}$ transfers from CANAL diversion stream temperatures at RKM 2.69 near the mouth of Walker Lake

B-59. Existing transfers versus $0.28 \mathrm{cms}$ transfers from SARONI diversion stream temperatures at RKM 2.69 near the mouth of Walker Lake 
B-60. Existing transfers versus $0.28 \mathrm{cms}$ transfers from CANAL diversion stream temperatures at RKM 2.69 near the mouth of Walker Lake .85

B-61. Existing transfers versus $0.28 \mathrm{cms}$ transfers from COLONY diversion stream temperatures at RKM 2.69 near the mouth of Walker Lake .86

B-62. Existing transfers versus $0.28 \mathrm{cms}$ transfers from TUNNEL diversion stream temperatures at RKM 2.69 near the mouth of Walker Lake

B-63. Existing transfers versus $0.71 \mathrm{cms}$ transfers from Bridgeport Reservoir stream temperatures at RKM 2.69 near the mouth of Walker Lake

B-64. Existing transfers versus $0.71 \mathrm{cms}$ transfers from Topaz Reservoir stream temperatures at RKM 2.69 near the mouth of Walker Lake

B-65. Existing transfers versus $0.71 \mathrm{cms}$ transfers from SSWJD diversion stream temperatures at RKM 2.69 near the mouth of Walker Lake

B-66. Existing transfers versus $1.41 \mathrm{cms}$ transfers from Bridgeport Reservoir stream temperatures at RKM 2.69 near the mouth of Walker Lake

B-67. Existing transfers versus $1.41 \mathrm{cms}$ transfers from Topaz Reservoir stream temperatures at RKM 2.69 near the mouth of Walker Lake

B-68. Existing transfers versus $1.41 \mathrm{cms}$ transfers from SSWJD diversion stream temperatures at RKM 2.69 near the mouth of Walker Lake

B-69. Existing transfers versus zero diversions from BNGHH diversion stream temperatures at RKM 2.69 near the mouth of Walker Lake

B-70. Existing transfers versus zero diversions from FOX diversion stream temperatures at RKM 2.69 near the mouth of Walker Lake

B-71. Existing transfers versus zero diversions from MCCAMP diversion stream temperatures at RKM 2.69 near the mouth of Walker Lake

B-72. Existing transfers versus zero diversions from SSWJD diversion stream temperatures at RKM 2.69 near the mouth of Walker Lake 
B-73. Existing transfers versus zero diversions from CANAL diversion stream temperatures at RKM 2.69 near the mouth of Walker Lake.

B-74. Existing transfers versus zero diversions from SARONI diversion stream temperatures at RKM 2.69 near the mouth of Walker Lake

B-75. Existing transfers versus zero diversions from GAGE diversion stream temperatures at RKM 2.69 near the mouth of Walker Lake

B-76. Existing transfers versus zero diversions from COLONY diversion stream temperatures at RKM 2.69 near the mouth of Walker Lake

B-77. Existing transfers versus zero diversions from TUNNEL diversion stream temperatures at RKM 2.69 near the mouth of Walker Lake

B-78. Existing transfers versus no diversions at all diversions (combined) stream temperatures at RKM 2.69 near the mouth of Walker Lake

B-79. Sensitivity analysis of Existing transfers with $0.94 \mathrm{~m}$ depth versus Existing transfers with $1.18 \mathrm{~m}$ depth ( $20 \%$ increase) stream temperatures at RKM 2.69 near the mouth of Walker Lake

B-80. Sensitivity analysis of Existing transfers scenario versus Existing transfers with full shade stream temperatures at RKM 2.69 near the mouth of Walker Lake .....95 


\section{CHAPTER 1}

INTRODUCTION

In the arid Walker Basin of western Nevada, low streamflows and warm stream temperatures limit native trout species (USFWS 1975). Agricultural diversions have decreased streamflows causing critically warm temperatures for native Lahontan cutthroat trout (LCT), Onochynchus clarki henshawi, threatening their survival (Neville et al. 2006; Sharpe et al. 2008). Currently, LCT have been extirpated from more than ninety percent of their historical habitat leaving low numbers of LCT in the Walker Basin (Coffin and Cowan 1995). Consequently, LCT are listed as a federally threatened species under the Endangered Species Act, requiring management for their recovery (USFWS 1975).

When river flows are low, the assimilative heat capacity of rivers is reduced and less energy is required to raise the temperature of the water (Poole and Berman 2001; Cassie 2006). Therefore, streams with low flows have less thermal mass and stream temperatures respond to atmospheric conditions faster than streams with high flows (Olden and Naimen 2010). Studies have also documented that insolation-dominated streams warm more readily with atmospheric conditions when riparian vegetation is removed (Brown 1970; Cassie 2006) and that more aquatic species occupy shaded and cooler stream reaches (Hawkins et al. 1997; Rutherford et al. 1997; Meyer et al. 2010).

One alternative to improve instream flows, cool stream temperatures, and possibly increase longitudinal connectivity is to purchase water rights for instream flows (Coffin and Cowan 1995; Yardas 2007). Purchasing water rights from willing sellers to increase flows are termed environmental water transfers (Isé and Sunding 1998; Landry 1998; 
Loomis et al. 2003; Acreman and Dunbar 2004; Katz 2006; Jones and Colby 2010). The economics of environmental water transfers have been studied for the Carson and Truckee Rivers in California and Nevada (Isé and Sunding 1998) and in the southwestern US (Jones and Colby 2010). In the Lahontan Valley purchase program in Nevada, some water rights holders retire low-quality land and profit from the sale (Isé and Sunding 1998), a trend that is increasing in the southwestern US (Jones in Colby 2010). In the Walker Basin, transfers averaging around 6.8 million cubic meters have taken place since this project has started, with potentially more to occur. Therefore, environmental water transfers are a promising means to increase streamflow in thermally impacted rivers, while also not harming water rights holders.

Several studies have examined the effects of increased flows and decreased stream temperatures on aquatic organisms (Conner et al. 1998; Sinokrot and Gulliver 2000; Meier et al. 2003; Chinnayakanahalli et al. 2011; Arismendi et al. 2013). Research has shown that low flows often coincide with warm stream temperatures in midsummer (Bartholow 1991; Danehy et al. 2004), and warmer temperatures negatively affect aquatic organisms (Conner et al. 2003; Harvey 2006). Specifically, Bartholow (1991) demonstrated that water diversions in the Poudre River in Colorado caused stream temperatures to exceed tolerance thresholds for rainbow (O. mykiss) and brown trout (Salmo trutta). Similarly, Conner et al. (2003) illustrated the benefits of higher instream flows for Chinook salmon (O. tshawytscha) survival in Idaho's Snake River. Null et al. (2010) modeled instream flows and stream temperatures on California's Shasta river to examine the quantity of water needed at specific reaches and times to maintain viable flows and stream temperature for coho salmon (O. kisutch). However, no research has 
specifically examined the effects of environmental water transfers on stream temperature, which is novel to this study. This is a timely and important area of research because determining when and where environmental water transfers are most effective may lead to improved thermal management for native fish species.

Research objectives for this project are: 1) determine when and where thermal refugia for LCT currently exist in the Walker River and its tributaries, and 2) simulate and quantify environmental water transfer effects on stream temperatures. Analysis of measured data will address objectives 1 and 2, and simulation modeling will address objective 3 .

Tennessee Valley Authority’s River Modeling System (RMS), a one-dimensional, process-based hydrodynamic and stream temperature model, simulates the effects of environmental water transfers on Walker River stream temperatures. This paper begins by describing Walker River geography, hydrology, and LCT distribution. Next, the RMS model is described, including input data and model output. Model runs are then described that simulate a range of environmental water transfers (both existing and potential transfers) at major diversions and upstream reservoirs. This brackets the range of potential environmental water transfer alternatives to improve understanding of when and where additional streamflow may improve stream temperatures for aquatic biota. Results compare environmental water transfer alternatives, focusing on the number of days and total river kilometers that stream temperature exceeds thermal thresholds for LCT. Overall, this research provides water managers and decision-makers with stream temperature estimates for alternative environmental water transfer scenarios, allowing them to make more informed restoration decisions. 


\section{CHAPTER 2}

\section{BACKGROUND}

\subsection{Study Site}

The mainstem Walker River is fed from two tributaries, the East and the West Walker Rivers. The source of these tributaries is snowmelt and groundwater from the east-slope Sierra Nevada Mountains in California. Headwaters of the Walker River in the highland Sierra Nevada ecoregion transition into the arid Great Basin ecoregion, ultimately draining into terminal Walker Lake (Jones 1992) (Figure 2-1). Climate varies from microthermal at high elevations with cold winters and heavy snowfall to desert at lower elevations with arid, hot summers (Sharpe et al. 2008).

The Walker Basin encompasses approximately $10,750 \mathrm{~km}^{2}$, of which approximately $450 \mathrm{~km}^{2}$ are irrigated farmland (Sharpe et al. 2008). Agriculture is the main land use in the Walker Basin. While agricultural land use is a small portion of land area, it has a disproportionate effect on the thermal regime of the Walker River because irrigation diversions remove approximately $80 \%$ of streamflow, based on average 19261996 conditions (Pahl 2000, Yardas 2007). Three major reservoirs have been built on the Walker Basin to provide water for irrigation. Bridgeport Reservoir on the East Walker River is $1950 \mathrm{~m}$ above sea level and has storage capacity of nearly 52 million cubic meters $\left(\mathrm{mm}^{3}\right)$. Topaz Reservoir is $1525 \mathrm{~m}$ above sea level, with storage capacity of 73 $\mathrm{mm}^{3}$. Both reservoirs are physical barriers to fish passage (Jones 1992). 


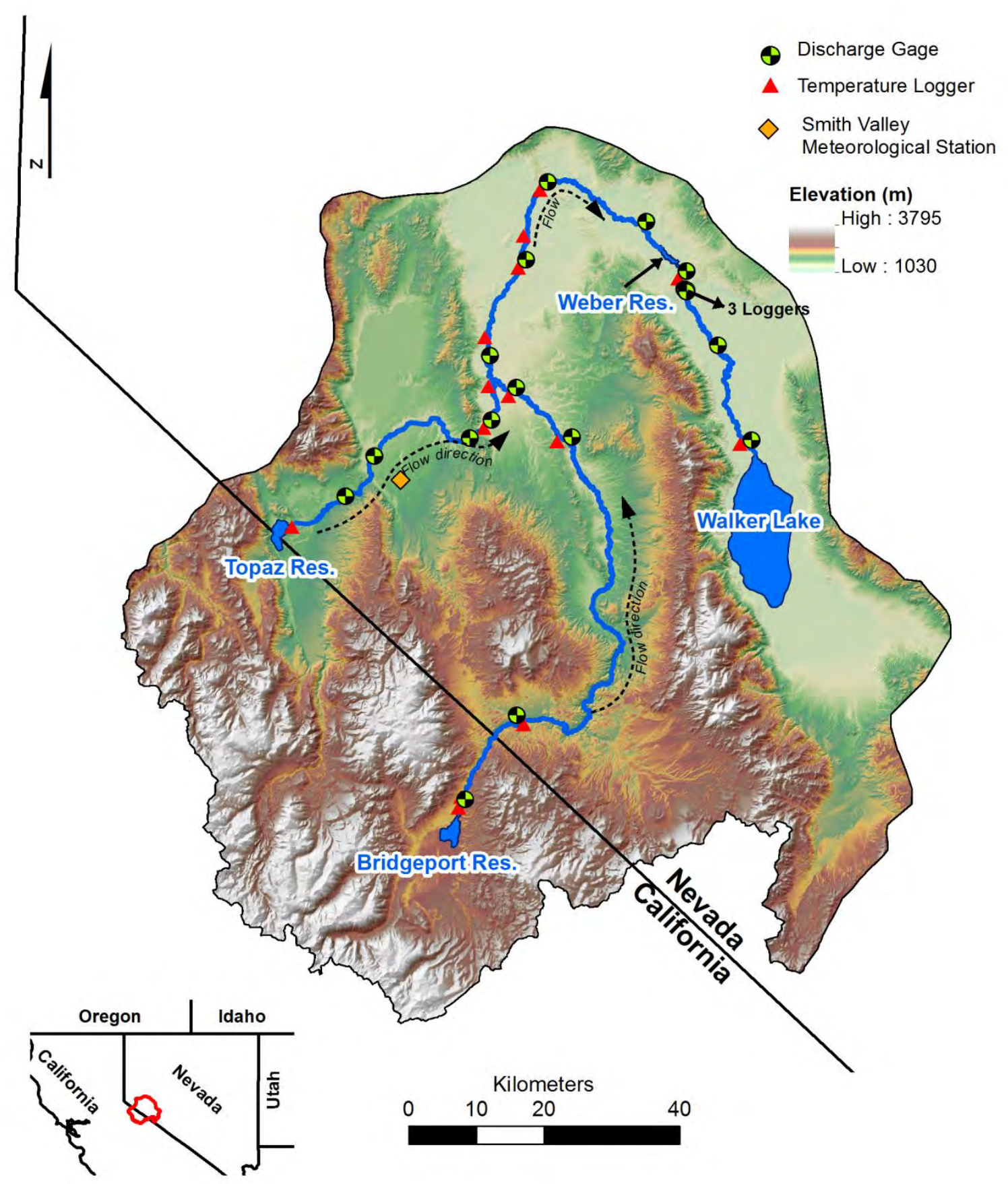

Figure 2-1: Walker River and tributaries with USGS discharge gages, stream temperature logger locations, and Smith Valley meteorological station. 


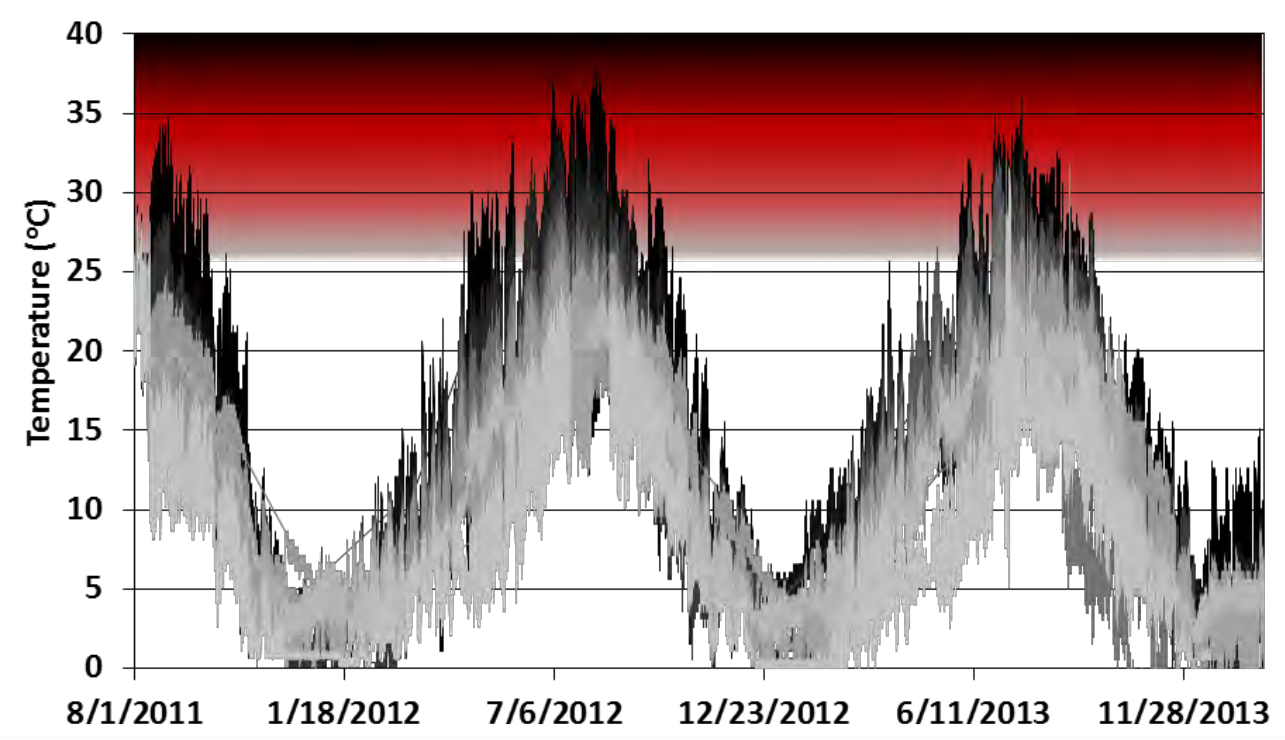

Figure 2-2: Measured hourly stream temperatures from 20 iButton temperature loggers distributed throughout the Walker Basin. Lighter hues are toward headwaters (elevation $>1500 \mathrm{~m})$ and darker hues are toward Walker Lake. Gradient indicates LCT acute $\left(28^{\circ} \mathrm{C}\right)$ upper thermal limit range (Dickerson and Vinyard 1999).

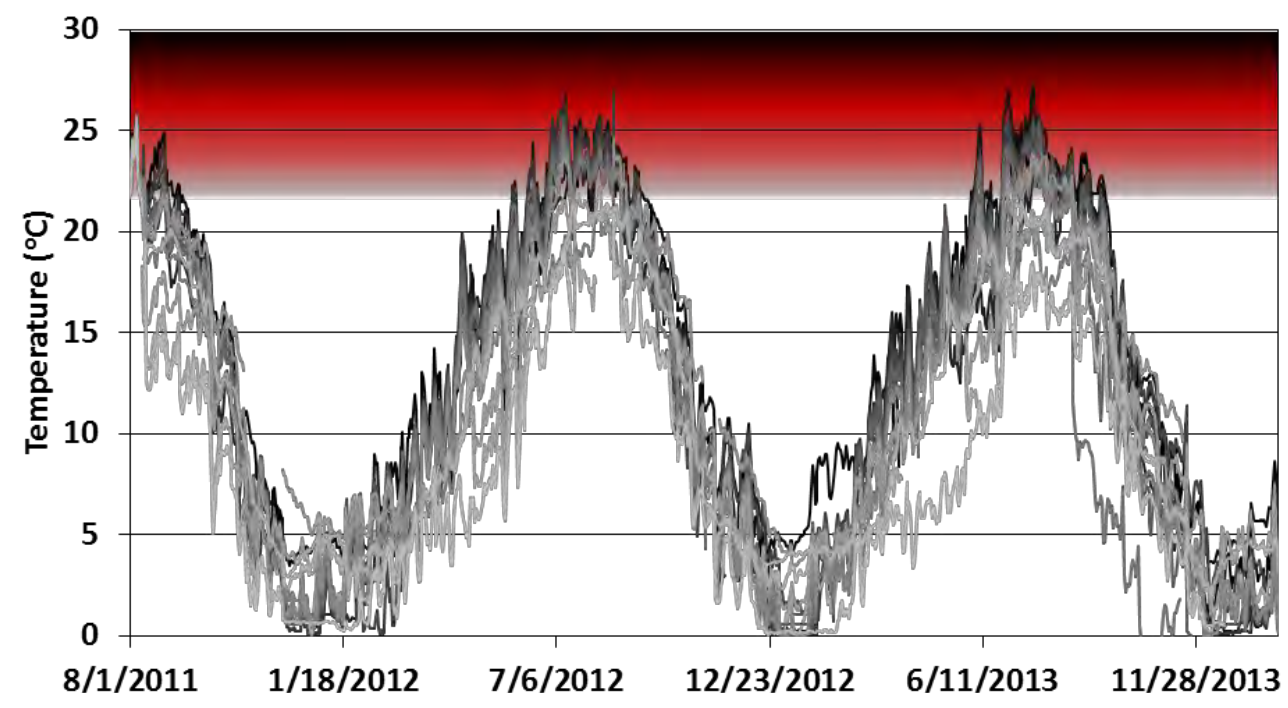

Figure 2-3: Measured 7 day average stream temperatures from 20 iButton temperature loggers distributed throughout the Walker Basin. Lighter hues are toward the headwaters (elevation $>1500 \mathrm{~m}$ ) and darker hues are toward Walker Lake. Gradient indicates LCT chronic 7 day average $\left(24^{\circ} \mathrm{C}\right)$ upper thermal limit range (Dickerson and Vinyard 1999). 
Weber Reservoir is located on the mainstem Walker River at $1285 \mathrm{~m}$ above sea level, with a storage capacity of $15 \mathrm{~mm}^{3}$. Water demands are such that low flows and warm stream temperatures are prevalent during the irrigation season from March 1 through October 31 (Yardas 2007). Irrigation tailwater sometimes returns to the river warmer than ambient river temperatures, further elevating stream temperatures (Yardas 2007). Measured stream temperatures exceed chronic and acute LCT limits, especially during dry years (Figure 2-2; Figure 2-3). Finally, streamflow is so low that Walker Lake is largely disconnected from the Walker River. LCT are no longer present in Walker Lake because of rising lake salinity and longitudinal fragmentation throughout the Walker River (Coffin and Cowan 1995; Sedinger et al. 2012).

\subsection{Walker Basin Lahontan Cutthroat Trout Distribution}

LCT are a threatened subspecies of cutthroat trout endemic to the Great Basin, whose range historically extended through eastern California, southeastern Oregon, and much of Nevada (Coffin and Cowan 1995) (Figure 2-4). Prior to the $20^{\text {th }}$ century, Walker River and Lake were home to a healthy population of LCT. Currently LCT extent is less than 3\% of their historical range in the Great Basin (Coffin and Cowan 1995; Dunham 1999) and small populations of wild LCT persist in high elevation Walker River headwater streams (e.g. By-Day Creek). Hatchery-raised LCT are stocked in lower elevations of the Walker Basin near Mason Valley Wildlife Refuge (Jones 1992; Coffin and Cowan 1995). 


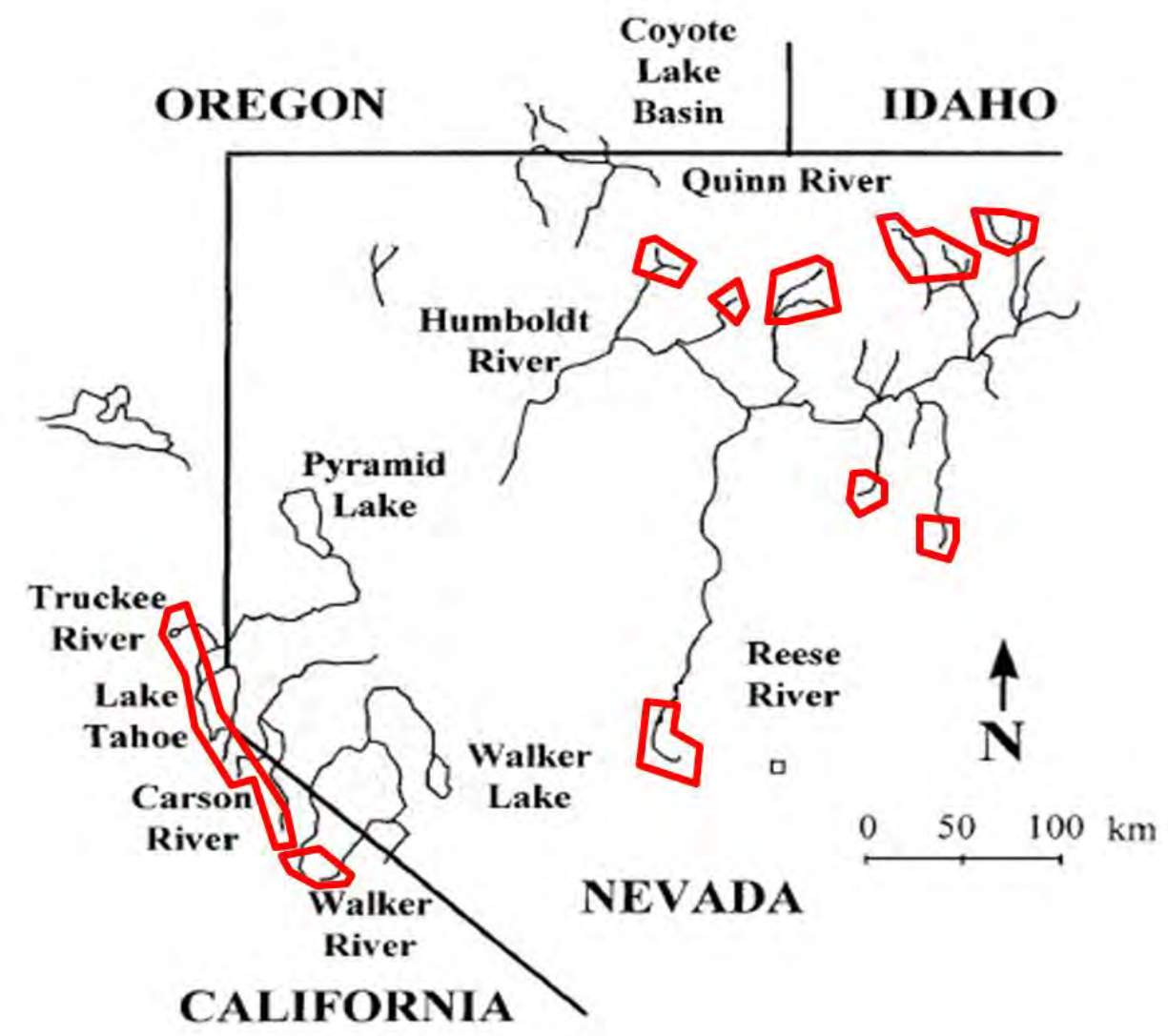

Figure 2-4: Historical LCT distribution and current estimated range outlined in red (adapted from Dunham et al. 1999).

Laboratory research suggests the chronic 7 day upper thermal limit for LCT is $24^{\circ} \mathrm{C}$ (Dickerson and Vinyard 1999). LCT can withstand acute ( $<2$ hours) stream temperatures of up to $28^{\circ} \mathrm{C}$ in the laboratory; however, field studies in Coyote Lake, Quinn River, and Humbolt River basins suggest that LCT presence is greatly reduced at these temperatures (Dunham et al. 2003). 


\section{CHAPTER 3}

\section{METHODS}

\subsection{Model Description}

This study uses Tennessee Valley Authority’s River Modeling System (RMS), which has a hydrodynamic module, ADYN, and a water quality module, RQUAL, to simulate streamflows and stream temperatures. The modules are run sequentially (Hauser and Schohl 2002). This model was chosen because it is open source, has riparian shading logic, and is process-based. The modeled spatial extent encompasses approximately 305 river kilometers, with an hourly time-step for years 2011 and 2012. 2011 was a wet year and 2012 was a dry year (CDEC 2013). The following sections describe the model, required input data, and model testing.

ADYN solves one-dimensional equations for conservation of mass and momentum (St. Venant equations) for velocity and depth using a four-point implicit finite difference scheme with weighted spatial derivatives (Hauser and Schohl 2002). Input requirements for ADYN are channel geometry, roughness coefficients, boundary conditions, and initial surface water elevations. ADYN outputs velocity and depth at each model node.

Simulated velocities and depths are passed to RQUAL, the water quality module. RQUAL uses the same geometric representation as ADYN to solve the Holly-Priessmann mass transport equation, which simulates the fate and transport (advection/diffusion) of heat energy to represent stream temperatures (Hauser and Schohl 2002). RQUAL accounts for water surface (evaporative cooling) and streambed (hyporheic thermal diffusivity) heat fluxes. Input requirements for RQUAL include meteorological data, 
riparian shading estimates, boundary temperatures, and initial water temperature throughout the modeled reach.

\subsection{Channel Geometry}

The Walker River is represented with 999 nodes from the outlets of Bridgeport and Topaz reservoirs to Walker Lake. Nodes are spaced evenly every $0.3 \mathrm{~km}$. Five-point river cross sections describe lateral geometry (Figure 3-1). Together, all center points represent channel gradient. River geometry was estimated from non-water penetrating one meter resolution Light Detection and Ranging (LiDAR) digital terrain models (DTM) of the Walker River and tributaries in 2011 (USFWS pers.comm. 2012). A river center line was estimated with the LiDAR DTM and lateral elevations recorded at $5 \mathrm{~m}$ and $25 \mathrm{~m}$ buffers (Figure 3-2). Since LiDAR does not penetrate the water surface, 20 river cross sections were measured to estimate center point depth. Sites were chosen for river accessibility. Using auto-level and real-time kinematic (RTK) GPS surveys, a representative depth of $0.94 \mathrm{~m}$ obtained from the 20 river cross sections was subtracted from LiDAR center points to represent river bed elevation. The roughness coefficient (Manning's n) was assumed to be uniform at 0.05 , which represents a natural stream channel with weeds and pools (Chapra 1997).

Weber Reservoir, located on the lower reach of the mainstem Walker River, is represented in the model as a spill-top weir. Cross-sectional data for the reservoir were unavailable, geometries and bathometry elevations were estimated gradually up to a maximum depth of $9.1 \mathrm{~m}$ in this approximately $6 \mathrm{~km}$ reach. 


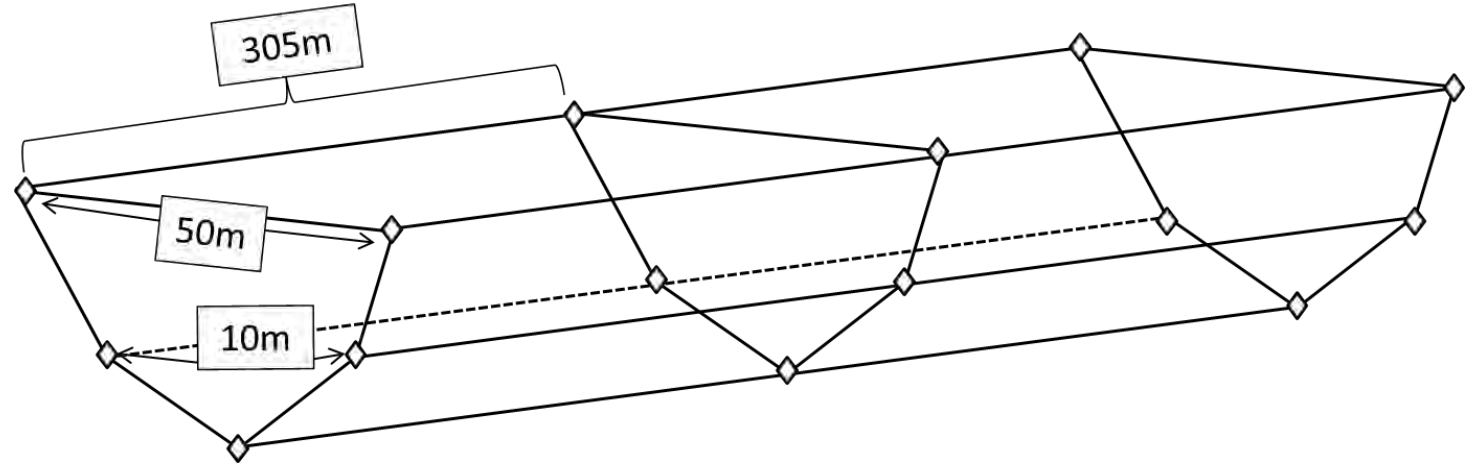

Figure 3-1: Schematic of 5 point river cross-sections.

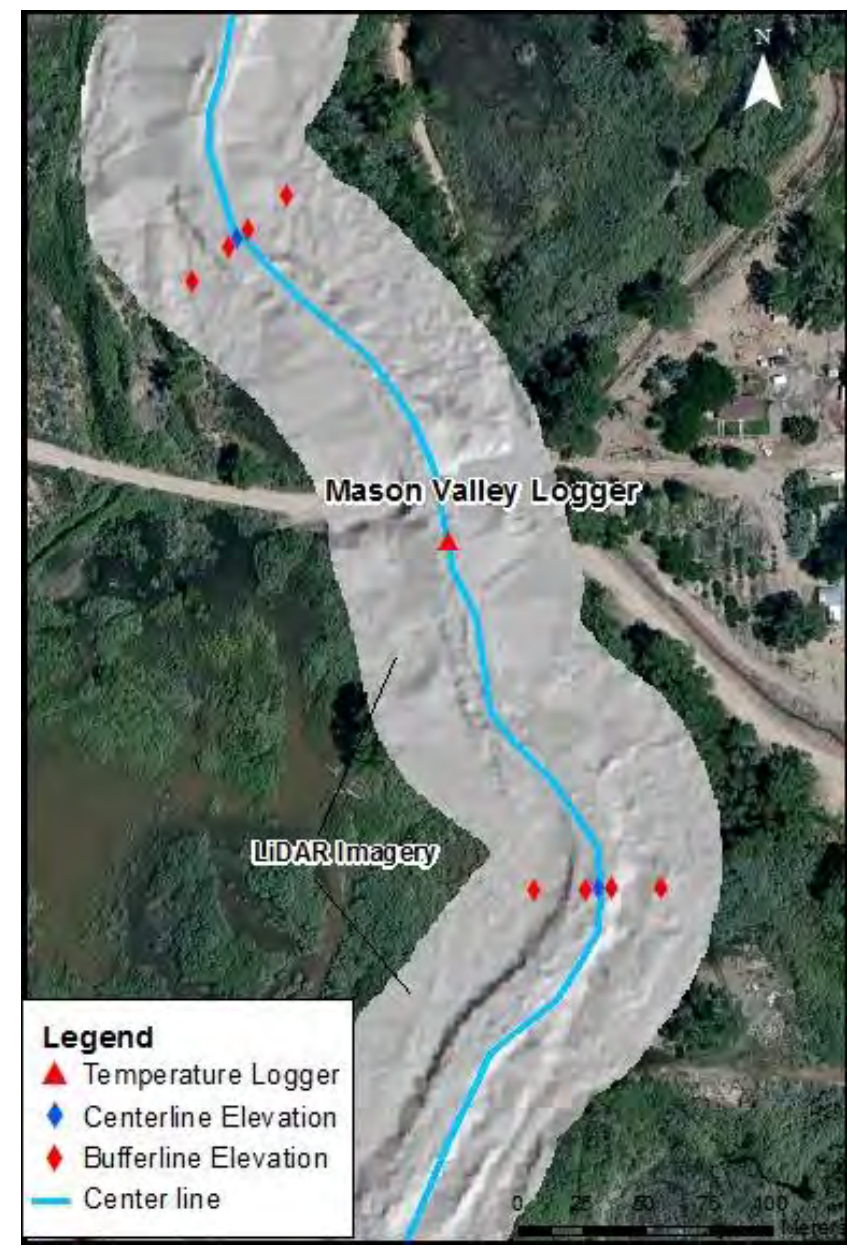

Figure 3-2: LiDAR image of the Walker River near Mason Valley Wildlife Refuge with buffer lines and center line elevation points. 


\subsection{Walker River Input Data and Model Development}

Daily streamflow data for 2011 and 2012 from eighteen USGS gages provide upstream boundary and initial streamflow conditions. Streamflow data were used to estimate diversions, accretions, and depletions by creating a water budget between gages in the East, West, and mainstem Walker River, and provide measured data for model calibration (USGS) (Figure 2-1). Hourly or 3-hour stream temperature data was collected with iButton temperature loggers at twenty sites throughout the Walker Basin starting in late July 2011 through December 2012 for model calibration and boundary condition inputs at Bridgeport Reservoir, Topaz Reservoir, Sweetwater Creek, and Wabuska Drain. Meteorological data was from the Smith Valley, NV weather station (1442 m) on the West Walker River, operated by Desert Reach Institute (DRI 2014) (Figure 2-1). Input meteorological data included cloud cover, air temperature, dewpoint temperature, air pressure, wind speed, and solar radiation (Table 3-1).

Table 3-1: Input data types, sources, collection periods, and collection sites

\begin{tabular}{|c|c|c|c|}
\hline Data Type & Source & $\begin{array}{l}\text { Collection } \\
\text { Period }\end{array}$ & Location \\
\hline $\begin{array}{l}\text { Center-Point } \\
\text { Geometry }\end{array}$ & Measured & 2012 & $\begin{array}{l}20 \text { sites along the East Walker and } \\
\text { Mainstem Walker to Walker Lake }\end{array}$ \\
\hline $\begin{array}{l}\text { Streambank } \\
\text { Geometry }\end{array}$ & $\begin{array}{l}\text { LiDAR - } \\
\text { USFWS }\end{array}$ & 2011 & $\begin{array}{l}\text { East, West, and Mainstem Walker } \\
\text { River }\end{array}$ \\
\hline Streamflow & USGS & $\begin{array}{l}\text { Jan. 1, 2011- } \\
\text { Dec. 31, 2012 }\end{array}$ & $\begin{array}{l}18 \text { USGS stations along the East, } \\
\text { West, and Mainstem Walker River }\end{array}$ \\
\hline $\begin{array}{l}\text { Meteorological } \\
\text { Data }\end{array}$ & UNR-DRI & $\begin{array}{l}\text { Jan. 1, 2011- } \\
\text { Dec. 31, 2012 }\end{array}$ & Smith Valley, NV station \\
\hline $\begin{array}{c}\text { Stream } \\
\text { Temperature }\end{array}$ & Measured & $\begin{array}{l}\text { Aug 1, 2011- } \\
\text { Dec. 31, 2012 }\end{array}$ & $\begin{array}{l}20 \text { locations throughout the East, } \\
\text { West, and Mainstem Walker River }\end{array}$ \\
\hline
\end{tabular}


Water diversion data were unavailable and were instead estimated by creating a water budget from streamflow data and Walker Basin irrigation documents (Jones 1992; Pahl 2000; WRIT 2003; Yardas 2007; Sharpe et al. 2008; TNC 2013). Locations of major diversions were determined from the National Hydrography Dataset and Google Earth aerial imagery. During irrigation season, more depletions, or water losses, occur between USGS gages than occur outside of the irrigation season. Therefore, diversions were initially assumed to be $80 \%$ of depletions between gages and then adjusted in calibration (Table 3-2). When multiple major diversions were present between USGS gages, each diversion was assigned a percentage of depleted flow based on relative diversion size from the irrigation documents (Table 3-2). For instance, if a depletion of $10 \mathrm{cms}$ occurred in EW Reach 2 (which has the FOX and BNGHH diversions - see Table 3-2 for diversion acronyms), then $80 \%$ of depleted $\mathrm{cms}$ were assigned to the diversions at this location, where FOX diversion received $5.5 \mathrm{cms}$ and BNGHH diversion received 2.5 cms because diversion reports indicated the FOX diversion is larger than BNGHH (Table 3-2; Figure 3-3). The remaining 20\% the depletions were assumed to be natural losses. On days with accretions, or water gains, between USGS gages, diversions were assumed to be zero. Final diversion percentages are reported in Table 3-2. Accretions could be from springs, ephemeral drainages, agricultural returns flows, etc. Similarly, depletions could be from small agricultural diversions, evapotranspiration, groundwater sinks, etc. The Walker River had twelve major accretion and depletion reaches (Figure 3-3).

Riparian vegetation height was estimated by averaging vegetation height on each bank for every modeled node using LiDAR DTMs (T. Landis, pers.comm.). Solar radiation was measured with a pyranometer on stream banks where no significant riparian 
vegetation was present, beneath medium height vegetation (mixed shrub) consisting mainly of willows $(4.57-9.14 \mathrm{~m})$, and beneath tall vegetation (large trees) consisting mainly of cottonwoods $(>9.14 \mathrm{~m})$. These measurements were made on sunny days from August 10-12, 2012 at three different sites for each of the three vegetation height classes. Solar radiation measured under each vegetation height category was averaged, then divided by full insolation to determine solar radiation transmittance through riparian canopies. Solar radiation transmittance for each vegetation height category is a follows: 1) short to no vegetation $(0-4.6 \mathrm{~m}$ tall $)$ with a solar transmittance of $100 \%, 2)$ medium vegetation (4.6-9.1 $\mathrm{m}$ tall) with a solar transmittance of $9 \%$, and 3$)$ tall vegetation $(>9.1 \mathrm{~m}$ tall) with a solar transmittance of $14 \%$.

Table 3-2: Diversion percentages and locations.

\begin{tabular}{|c|c|c|c|c|}
\hline Location & $\begin{array}{c}\text { River } \\
\text { Km }\end{array}$ & Diversion Name & $\begin{array}{c}\text { Percent } \\
\text { depletion } \\
\text { assigned to } \\
\text { diversion }\end{array}$ & $\begin{array}{l}\text { Total depletion } \\
\text { diverted } \\
\text { between gages }\end{array}$ \\
\hline \multirow{3}{*}{$\begin{array}{c}\text { WW } \\
\text { Reach } 1\end{array}$} & 27.71 & Saroni Canal (SARONI) & $11 \%$ & \multirow{3}{*}{$70 \%$} \\
\hline & 26.01 & Colony-Plymouth Canal (COLONY) & $39 \%$ & \\
\hline & 24.68 & Gage-Petersen Canal (GAGE) & $20 \%$ & \\
\hline $\begin{array}{c}\text { WW } \\
\text { Reach } 3\end{array}$ & 8.16 & Tunnel Ditch (TUNNEL) & $88 \%$ & $88 \%$ \\
\hline \multirow{2}{*}{$\begin{array}{c}\text { EW } \\
\text { Reach } 2\end{array}$} & 77.40 & $\begin{array}{l}\text { Baker-SnyderNelson } \\
\text { Greenwood } \\
\text { Hall }\end{array}$ & $25 \%$ & \multirow[t]{2}{*}{$80 \%$} \\
\hline & 76.26 & Fox-Mickey Ditches (FOX) & $55 \%$ & \\
\hline \multirow[b]{2}{*}{$\begin{array}{c}\text { WR } \\
\text { Reach } 1\end{array}$} & 63.54 & Mcleod-Campbell Ditches (MCCAMP) & $33 \%$ & \multirow[b]{2}{*}{$80 \%$} \\
\hline & 61.27 & $\begin{array}{cc}\text { SAB } & \text { Joggles } \\
\text { Sciariani } & \text { Dairy } \\
\text { West-Hyland } & \text { Ditches (SSWJD) }\end{array}$ & $47 \%$ & \\
\hline
\end{tabular}




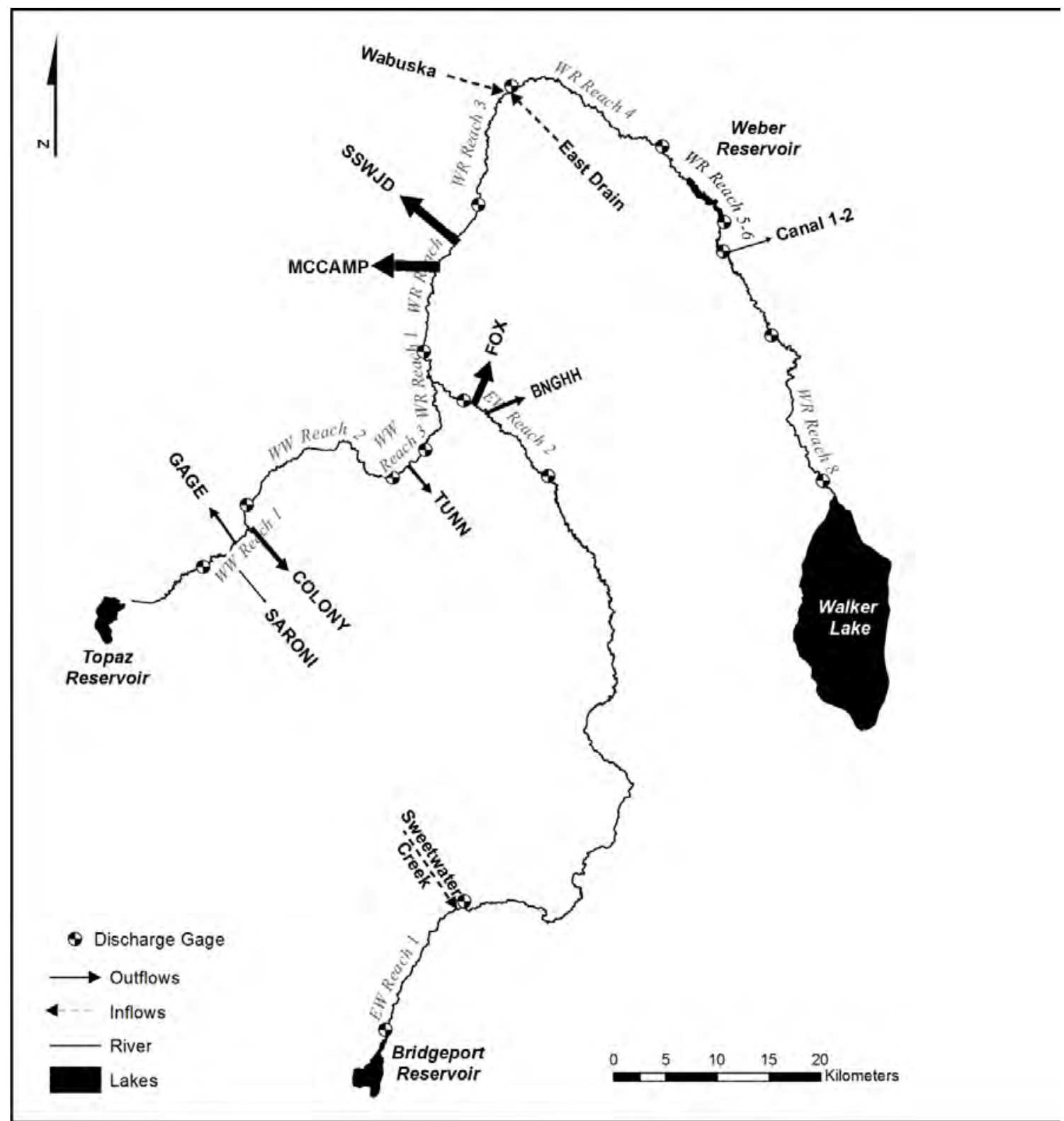

Figure 3-3: Major inflows, outflows, and accretion/depletion reaches for the Walker River and its tributaries. Outflow arrow thickness is relative to average annual diversion rate (cubic meter/year) (Yardas 2007); inflows arrows are not scaled with inflow rate. Diversion acronyms are provided in Table 3-2. EW stands for East Walker, WW stands for West Walker, and WR stands for the mainstem Walker River.

\subsection{Model Calibration}

Modeled 2011 and 2012 streamflow and temperature were compared to measured data to test and calibrate models. Nash-Sutcliffe efficiency (NSE), percent bias (PBIAS), 
ratio of root mean square error to standard deviation of measured data (RSR), and root mean square error (RMSE) were calculated for streamflow and stream temperature to quantify model fit (see appendix for formulas and stream temperature calibration plots) (Moraisi et al. 2007). NSE is a normalized statistic that determines the relative magnitude of residual variance compared to measured variance, indicating how well measured versus modeled data fits a 1:1 line. The range is $-\infty$ to 1 , where 1 is optimal. PBIAS measures the average tendency of the simulated data to be larger or smaller than observed counterpoints. Optimal values are 0 , where positive values indicate model underestimation and negative values indicate overestimation. RSR incorporates the benefits of error index statistics and includes a scaling and normalizing factor so that the resulting statistic and reported values can apply to various constituents, where the range of values are 0 to a positive large constant, with an optimal value of 0 . RMSE is a common statistic that measures the difference between a modeled value and a measured value. Together all of these statistics combine to provide a robust statistical description for assessing hydrologic model fit (Moraisi et al. 2007).

The model was calibrated by adjusting extreme hourly changes (positive or negative) flow timing, diversion percentages, and heat exchange coefficients to improve model fit (Table 3-2; Table 3-3). Streamflows and diversion percentages were adjusted in some cases to maintain enough streamflow $(\sim 0.06-0.14 \mathrm{cms})$ so that models did not crash. Added water was subtracted downstream (at the next node) so as to maintain conservation of water mass. Twelve USGS streamflow gages and 10 iButton temperature loggers were used for calibration. Table 3-3 lists parameters that were adjusted to calibrate the stream temperature module, RQUAL. 
Table 3-3: Parameters calibrated in RQUAL.

\begin{tabular}{|c|c|c|c|}
\hline Parameter & Parameter Description & $\begin{array}{c}\text { Final } \\
\text { Value }\end{array}$ & $\begin{array}{c}\text { Suggested range } \\
\text { or value }\end{array}$ \\
\hline AA & $\begin{array}{c}\text { Wind speed coefficient in wind-driven } \\
\text { evaporative cooling }\end{array}$ & $\begin{array}{c}1.8 \mathrm{e}- \\
09\end{array}$ & $0.5 \mathrm{e}-9$ to $4 \mathrm{e}-9$ \\
\hline $\mathrm{BB}$ & $\begin{array}{c}\text { Wind exponent in wind-driven evaporative } \\
\text { cooling }\end{array}$ & $0.9 \mathrm{e}-9$ & $1 \mathrm{e}-9$ to $3 \mathrm{e}-9$ \\
\hline $\mathrm{XL}$ & Upper layer bed thickness $(\mathrm{cm})$ & 21 & 5 to 50 \\
\hline $\mathrm{XL} 2$ & Deep layer bed thickness $(\mathrm{cm})$ & 200 & 10 to 200 \\
\hline DIF & Thermal diffusivity of bed material $\left(\mathrm{cm}^{2} / \mathrm{hr}\right)$ & 50 & $25-50$ \\
\hline $\mathrm{CV}$ & Bed heat storage capacity $\left(\mathrm{cal}^{3} / \mathrm{cm}^{3}{ }^{\circ} \mathrm{C}\right)$ & 0.68 & $0.4-0.7$ \\
\hline BETW & $\begin{array}{c}\text { Fraction of solar radiation absorbed in water } \\
\text { surface }\end{array}$ & 0.4 & 0.4 \\
\hline BEDALB & Albedo of bed material & 0.1 & 0.1 to 0.5 \\
\hline SHSOL & $\begin{array}{c}\text { Fraction of solar radiation absorbed by shaded } \\
\text { water }\end{array}$ & 0.4 & 0.0 to 1.0 \\
\hline SHDBT & $\begin{array}{c}\text { Fraction of drybulb/dewpoint temperatures } \\
\text { depression by which drybulb temperature is } \\
\text { cooler over shaded water }\end{array}$ & 0.5 & 0.0 to 1.0 \\
\hline
\end{tabular}

\subsection{Model Runs}

Environmental water transfers were represented as reduced diversions during irrigation season. (Note: $014 \mathrm{cms}$ equals 5 cubic feet per second, cfs, $0.28 \mathrm{cms}$ equals 10 cfs, 0.71 equals $25 \mathrm{cfs}$, and $1.41 \mathrm{cms}$ equals $50 \mathrm{cfs}$.) Simulated water transfers were constrained to be smaller than actual diversions so extra water was not added to the system. Forty model runs each were completed for 2011 and 2012, which are described below. Table 3-4 summarizes models runs.

Forty model runs each were completed for 2011 and 2012. One alternative represented existing water transfers throughout the irrigation season (E. Borgen pers.comm. 2014) (Table 3-4). Next, model run scenarios were completed analyzing potential daily water transfers of $0.14 \mathrm{cms}$ and $0.28 \mathrm{cms}$ at each diversion point and Bridgeport Reservoir on the East Walker. Bridgeport Reservoir was chosen for these additions because of already existing transfers there and due to the average cooler stream 
temperatures released from Bridgeport versus Topaz Reservoir. To further improve understanding of the water transfers necessary to reduce stream temperatures, sensitivity testing of daily additions of $0.71 \mathrm{cms}$ and $1.41 \mathrm{cms}$ were completed for the large diversions: Sab, Sciarani, West-Hyland, and Joggles and Dairy ditches (SSWJD), the East Walker upstream reservoir (Bridgeport), and the West Walker upstream reservoir (Topaz) (Table 3-4). These locales were chosen simply because they are the only sites in the Walker Basin that could feasibly accommodate such transfers. Diversion Off model runs simulated the individual removal of each major point of diversion singly, represented in the model by setting individual diversions to zero one at a time (i.e. nine model runs). No Diversions simulations were completed for both years, by setting all diversions to zero (Table 3-4). Finally, two additional runs were done to test sensitivity to depth, with an increase in deepest center points by $20 \%$, and increases of full shading at 10 locations throughout the Walker Basin (Table 3-4). 
Table 3-4: Model runs for years 2011 and 2012. NOTE: Diversion Off additions are the last $\mathrm{cms}$ reported for each diversion.

\begin{tabular}{|c|c|}
\hline Model Run & Run Description \\
\hline Existing Transfers & $\begin{array}{c}\text { Average of } 0.81 \mathrm{cms} \text { added in } 2011 \text { and } 0.09 \text { added in } 2012 \text { to } \\
\text { Bridgeport, BNGHH, SSWJD, GAGE, and COLONY } \\
\text { (Borgen, pers. comm.) }\end{array}$ \\
\hline Bridgeport & Daily Instream flow additions of $0.14,0.28,0.71$, or $1.41 \mathrm{cms}$ \\
\hline Topaz & Daily Instream flow additions of 0.71 or $1.41 \mathrm{cms}$ \\
\hline SARON & Daily Instream flow additions of $0.14,0.28$, or $0.32 \mathrm{cms}$ \\
\hline COLONY & Daily Instream flow additions of $0.14,0.28$, or $1.13 \mathrm{cms}$ \\
\hline GAGE & Daily Instream flow additions of $0.14,0.28$, or $0.51 \mathrm{cms}$ \\
\hline TUNNEL & Daily Instream flow additions of $0.14,0.28$, or $0.83 \mathrm{cms}$ \\
\hline $\mathrm{BNGHH}$ & Daily Instream flow additions of $0.14,0.28$, or $0.58 \mathrm{cms}$ \\
\hline FOX & Daily Instream flow additions of $0.14,0.28$, or $0.85 \mathrm{cms}$ \\
\hline MCCAMP & Daily Instream flow additions of $0.14,0.28$, or $1.30 \mathrm{cms}$ \\
\hline SSWJD & $\frac{\text { Daily Instream flow additions of }}{0.76 \mathrm{cms}} 0.14,0.28,0.71,1.41$, or \\
\hline CANAL & Daily Instream flow additions of $0.14,0.28$, or $0.45 \mathrm{cms}$ \\
\hline No Diversions & Daily Instream flow additions of $0.75 \mathrm{cms}$ at all sites \\
\hline Depth Sensitivity & Increased Depth by $20 \%$ on all center points \\
\hline Shade Sensitivity & Increased to full shade at ten unshaded rkms \\
\hline
\end{tabular}




\section{CHAPTER 4}

\section{RESULTS}

Modeled winter stream temperatures under-predicted measured temperatures by up to $10^{\circ} \mathrm{C}$. This may be due to model code that ignores the heat of condensation for warmer river systems such as the Mississippi River (G. Hauser, pers.comm. 2014). Rather than modify model code, results focus on irrigation season from April 1-October 31, the pertinent time period for environmental water transfers.

\subsection{Calibration Results}

\subsubsection{Streamflow}

Overall, modeled streamflow during irrigation season (April 1 - October 31) fits measured data well for 2011 and 2012 (Figure 4-1, Figure 4-2). Average annual 2011 irrigation season streamflow has an NSE of 0.99 , RSR of 0.09 , PBIAS of $0.27 \%$, and an RMSE of $0.87 \mathrm{cms}$ and 2012 irrigation season streamflow has an NSE of 0.92, RSR of 0.23 , PBIAS of $10.90 \%$, and a RMSE of $0.17 \mathrm{cms}$ (Table 4-1). These statistics indicate very good model performance for both years (Moriasi et al. 2007). Streamflow data were used to close the water balance by estimating accretions and depletions between the reaches for model calibration, which contributes to the tight model fit

\subsubsection{Steam Temperature}

RMS produced a good representation of stream temperature for years 2011 and 2012 (Table 4-2). Measured stream temperatures were available from August 1-October 31, 2011 and modeled temperatures were compared during this period, with an annual average NSE of 0.91 , RSR of 0.276 , PBIAS of $2.09 \%$, and a RMSE of $2.01{ }^{\circ} \mathrm{C}$ (Table 42; Figure 4-3). Stream temperatures were available throughout 2012 irrigation season, 
and average annual measured versus modeled NSE was 0.90 , RSR was 0.29 , PBIAS was $7.87 \%$, and RMSE was $2.14{ }^{\circ} \mathrm{C}$ (Table 4-2; Figure 4-4).

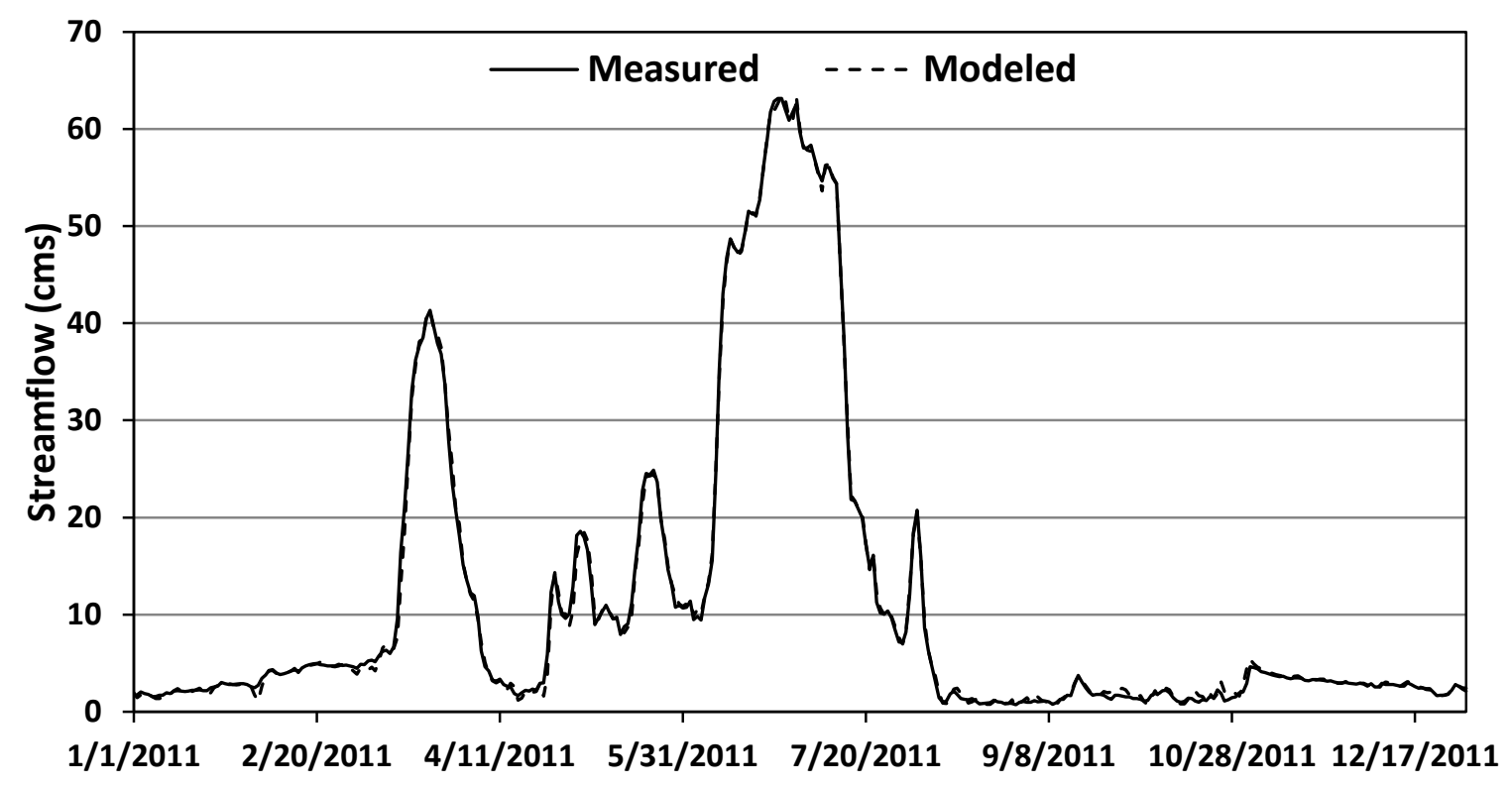

Figure 4-1: Measured and modeled hourly streamfow for irrigation season 2011 at river $\mathrm{km} 94.02$

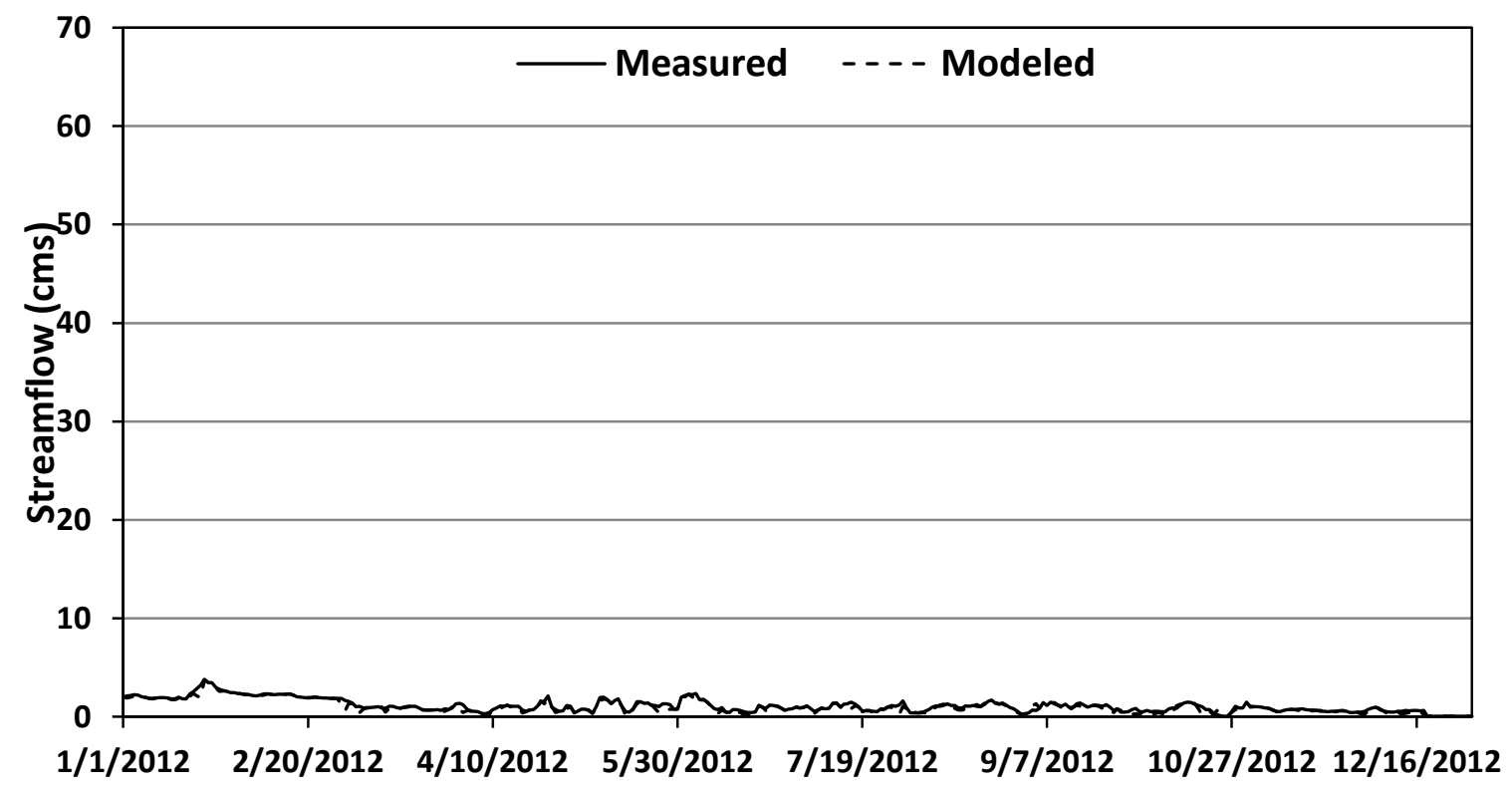

Figure 4-2: Measured and modeled hourly streamflow for irrigation season 2012 at river $\mathrm{km} 94.02$. 
Table 4-1: Measured versus modeled 2011 and 2012 streamflow statistics.

\begin{tabular}{|c|c|c|c|c|c|c|}
\hline$\frac{2011}{\text { River }}$ & $\begin{array}{c}\text { River } \\
\text { Km }\end{array}$ & $\begin{array}{l}\text { RMSE } \\
\text { (cms) }\end{array}$ & $\begin{array}{c}\text { NSE } \\
\text { (unitless) }\end{array}$ & $\begin{array}{c}\text { RSR } \\
\text { (unitless) }\end{array}$ & $\begin{array}{c}\text { PBIAS } \\
(\%)\end{array}$ & $\begin{array}{c}n \\
\text { (days) }\end{array}$ \\
\hline \multirow{2}{*}{$\begin{array}{c}\text { East } \\
\text { Walker }\end{array}$} & 137.4 & 0.71 & 0.99 & 0.10 & 0.10 & 245 \\
\hline & 121.8 & 0.75 & 0.98 & 0.14 & 0.10 & 245 \\
\hline $\begin{array}{c}\text { Reach } \\
\text { Statistics }\end{array}$ & - & 0.73 & 0.99 & 0.12 & 0.10 & 245 \\
\hline \multirow{7}{*}{ Walker } & 112.4 & 0.69 & 0.99 & 0.04 & 0.04 & 245 \\
\hline & 94.3 & 0.64 & 0.99 & 0.03 & 2.94 & 245 \\
\hline & 77.8 & 0.67 & 0.99 & 0.04 & -0.04 & 245 \\
\hline & 53.4 & 1.46 & 0.99 & 0.12 & 9.83 & 245 \\
\hline & 41.8 & 1.24 & 0.99 & 0.10 & -3.14 & 245 \\
\hline & 27.1 & 0.83 & 0.99 & 0.10 & -2.84 & 245 \\
\hline & 2.4 & 2.20 & 0.96 & 0.20 & -2.06 & 245 \\
\hline $\begin{array}{c}\text { Reach } \\
\text { Statistics }\end{array}$ & - & 1.10 & 0.99 & 0.08 & 0.67 & 245 \\
\hline \multirow{3}{*}{$\begin{array}{c}\text { West } \\
\text { Walker }\end{array}$} & 37.3 & 0.36 & 0.96 & 0.20 & -2.06 & 245 \\
\hline & 15.0 & 0.27 & 1.00 & 0.02 & 0.01 & 245 \\
\hline & 10.4 & 0.60 & 0.99 & 0.05 & 0.36 & 245 \\
\hline \multirow[t]{2}{*}{$\begin{array}{c}\text { Reach } \\
\text { Statistics }\end{array}$} & - & 0.41 & 0.98 & 0.09 & -0.56 & 245 \\
\hline & Average & 0.87 & 0.98 & 0.09 & 0.27 & 245 \\
\hline \multicolumn{7}{|l|}{$\frac{2012}{\text { River }}$} \\
\hline \multirow{2}{*}{$\begin{array}{c}\text { East } \\
\text { Walker }\end{array}$} & 137.4 & 0.13 & 0.97 & 0.17 & 0.73 & 245 \\
\hline & 121.8 & 0.21 & 0.63 & 0.60 & 1.97 & 245 \\
\hline $\begin{array}{c}\text { Reach } \\
\text { Statistics }\end{array}$ & - & 0.17 & 0.80 & 0.39 & 1.35 & 245 \\
\hline \multirow{7}{*}{ Walker } & 112.4 & 0.35 & 0.96 & 0.19 & -3.92 & 245 \\
\hline & 94.3 & 0.25 & 0.75 & 0.50 & -12.51 & 245 \\
\hline & 77.8 & 0.26 & 0.94 & 0.24 & -11.70 & 245 \\
\hline & 53.4 & 0.11 & 0.92 & 0.27 & 0.07 & 245 \\
\hline & 41.8 & 0.08 & 0.97 & 0.16 & 0.02 & 245 \\
\hline & 27.1 & 0.06 & 0.97 & 0.17 & 71.65 & 245 \\
\hline & 2.4 & 0.06 & 0.96 & 0.19 & 83.96 & 245 \\
\hline $\begin{array}{c}\text { Reach } \\
\text { Statistics }\end{array}$ & - & 0.17 & 0.92 & 0.25 & 18.22 & 245 \\
\hline \multirow{3}{*}{$\begin{array}{c}\text { West } \\
\text { Walker }\end{array}$} & 37.3 & 0.13 & 0.99 & 0.07 & 0.00 & 245 \\
\hline & 15.0 & 0.16 & 0.99 & 0.07 & 0.02 & 245 \\
\hline & 10.4 & 0.22 & 0.99 & 0.11 & 0.47 & 245 \\
\hline \multirow[t]{2}{*}{$\begin{array}{c}\text { Reach } \\
\text { Statistics }\end{array}$} & - & 0.17 & 0.99 & 0.08 & 0.16 & 245 \\
\hline & Average & 0.17 & 0.92 & 0.23 & 10.90 & 245 \\
\hline
\end{tabular}


In general, model results are very good in comparison with many of the studies examined in Moriasi et al. (2007). Model fit is even better in the dry year 2012, which reduces uncertainty for hydrologic conditions when environmental water transfers are most likely to be utilized to maintain instream habitat for native fish and wildlife. The large difference in spatial and temporal scale of this model should be considered in interpretation of these results, where large amount of data in this study produce better results than those described in Moraisi et al. (2007).

\subsection{Historical Conditions}

Modeled Historical Conditions in 2011 and 2012 indicated stream temperatures were near or above the chronic average 7 day thermal limit of $24^{\circ} \mathrm{C}$, as well as the acute daily maximum thermal limit of $28^{\circ} \mathrm{C}$ during summer weeks of July 1 - August 26 for both years, from approximately river kilometer 160 through 65 and from river kilometer 25 to the mouth of Walker Lake (Table 4-3). For wet year 2011, the majority of the East Walker River is not thermally limited. However, much of the West Walker and the majority of the mainstem Walker Rivers are thermally limited or near thermal limitation (Table 4-3). During dry year 2012, the East Walker River is not thermally limited until the lower reaches near the confluence with the mainstem (Table 4-3). Again, the West Walker and the Mainstem were generally thermally limited during summer. 


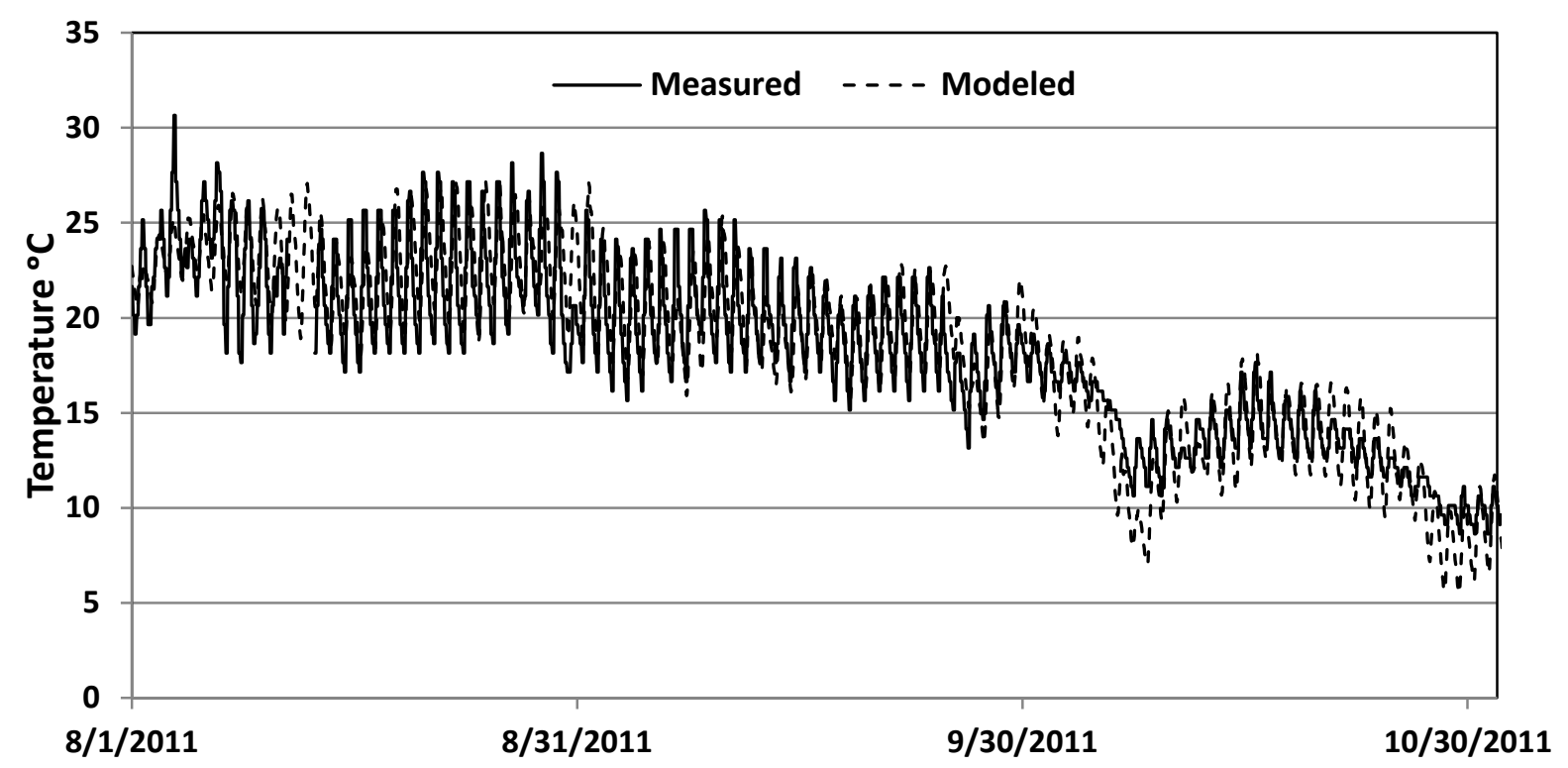

Figure 4-3: Measured and modeled hourly stream temperatures for irrigation season 2011 at river $\mathrm{km} 94.02$.

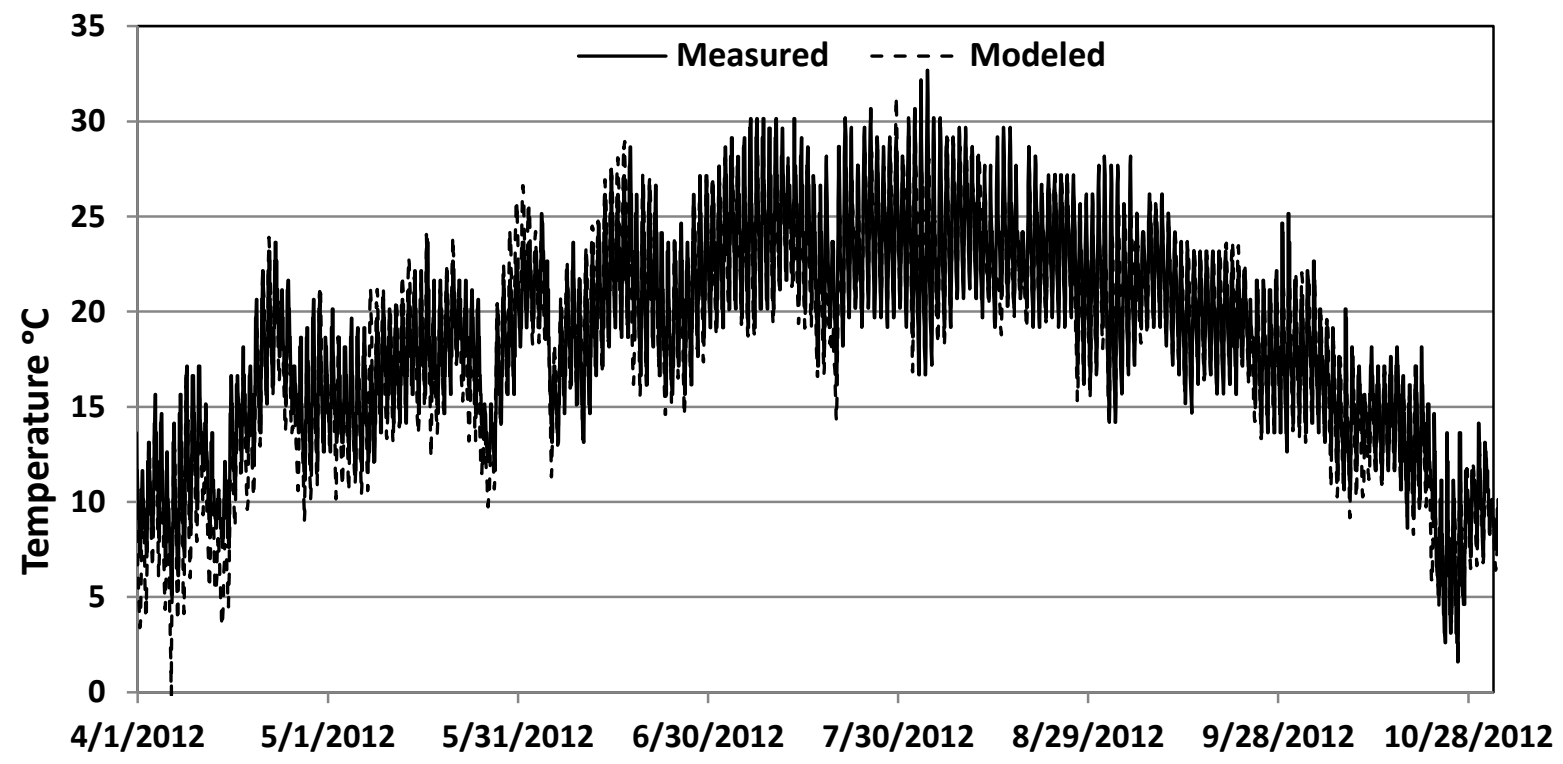

Figure 4-4: Measured and modeled hourly stream temperatures for irrigation season 2012 at river $\mathrm{km} 94.02$. 
Table 4-2: Measured versus modeled 2011 and 2012 stream temperature statistics.

\begin{tabular}{|c|c|c|c|c|c|c|}
\hline$\frac{2011}{\text { River }}$ & River km & $\begin{array}{l}\text { RMSE } \\
\left({ }^{\circ} \mathrm{C}\right)\end{array}$ & $\begin{array}{c}\text { NSE } \\
\text { (unitless) }\end{array}$ & $\begin{array}{c}\text { RSR } \\
\text { (unitless) }\end{array}$ & PBIAS (\%) & $\begin{array}{c}n \\
\text { (Hours) }\end{array}$ \\
\hline \multirow{3}{*}{$\begin{array}{c}\text { East } \\
\text { Walker }\end{array}$} & 225.4 & 1.69 & 0.94 & 0.24 & 5.11 & 2172 \\
\hline & 135.6 & 1.36 & 0.96 & 0.19 & 1.85 & 2173 \\
\hline & 121.5 & 1.35 & 0.97 & 0.19 & 1.18 & 2173 \\
\hline $\begin{array}{c}\text { Reach } \\
\text { Statistics }\end{array}$ & - & 1.47 & 0.96 & 0.21 & 2.71 & - \\
\hline \multirow{5}{*}{ Walker } & 94.0 & 1.94 & 0.94 & 0.25 & -0.07 & 2167 \\
\hline & 87.6 & 1.84 & 0.94 & 0.24 & -3.34 & 2169 \\
\hline & 77.5 & 2.24 & 0.91 & 0.30 & 10.26 & 2174 \\
\hline & 46.1 & 1.68 & 0.94 & 0.25 & 1.51 & 2168 \\
\hline & 2.7 & 4.43 & 0.65 & 0.60 & -1.39 & 2173 \\
\hline $\begin{array}{c}\text { Reach } \\
\text { Statistics }\end{array}$ & - & 2.43 & 0.87 & 0.33 & 1.39 & - \\
\hline \multirow{2}{*}{$\begin{array}{c}\text { West } \\
\text { Walker }\end{array}$} & 39.7 & 1.48 & 0.96 & 0.21 & 3.86 & 2168 \\
\hline & 10.1 & 1.80 & 0.94 & 0.25 & 4.95 & 2174 \\
\hline \multirow[t]{2}{*}{$\begin{array}{c}\text { Reach } \\
\text { Statistics }\end{array}$} & - & 1.64 & 0.95 & 0.23 & 4.40 & - \\
\hline & Average & 2.01 & 0.91 & 0.28 & 2.09 & 2171 \\
\hline \multicolumn{7}{|l|}{$\frac{2012}{\text { River }}$} \\
\hline \multirow{3}{*}{$\begin{array}{c}\text { East } \\
\text { Walker }\end{array}$} & 225.4 & 2.10 & 0.89 & 0.33 & 10.262 & 5136 \\
\hline & 135.6 & 1.55 & 0.96 & 0.21 & -3.379 & 4813 \\
\hline & 121.5 & 2.38 & 0.89 & 0.33 & -3.731 & 5136 \\
\hline $\begin{array}{c}\text { Reach } \\
\text { Statistics }\end{array}$ & - & 2.01 & 0.91 & 0.29 & 1.05 & - \\
\hline \multirow{5}{*}{ Walker } & 94.0 & 1.88 & 0.94 & 0.24 & -4.372 & 5136 \\
\hline & 87.6 & 2.17 & 0.93 & 0.27 & -5.997 & 5136 \\
\hline & 77.5 & 2.55 & 0.98 & 0.37 & -1.034 & 5128 \\
\hline & 46.1 & 2.10 & 0.90 & 0.32 & -4.781 & 4343 \\
\hline & 2.7 & 3.93 & 0.74 & 0.51 & 97.003 & 5136 \\
\hline $\begin{array}{c}\text { Reach } \\
\text { Statistics }\end{array}$ & - & 2.53 & 0.87 & 0.34 & 16.16 & - \\
\hline \multirow{2}{*}{$\begin{array}{c}\text { West } \\
\text { Walker }\end{array}$} & 39.7 & 1.28 & 0.97 & 0.19 & -2.289 & 4341 \\
\hline & 10.1 & 1.43 & 0.96 & 0.21 & -0.633 & 5136 \\
\hline \multirow[t]{2}{*}{$\begin{array}{c}\text { Reach } \\
\text { Statistics }\end{array}$} & - & 1.36 & 0.96 & 0.20 & -1.46 & - \\
\hline & Average & 2.14 & 0.90 & 0.29 & 7.87 & 4922 \\
\hline
\end{tabular}


Table 4-3. Seven day average and maximum daily temperatures for summer weeks with Historical Conditions at selected river kilometers. Shaded cells indicate exceeded thresholds. Top table is 2011, bottom table is 2012 .

\begin{tabular}{|c|c|c|c|c|c|c|c|c|c|c|c|c|c|c|c|c|c|c|c|}
\hline & \multirow{2}{*}{$\frac{\text { River }}{\underline{k m}}$} & \multicolumn{2}{|c|}{$7 / 1 / 2011$} & \multicolumn{2}{|c|}{$7 / 8 / 2011$} & \multicolumn{2}{|c|}{$7 / 15 / 2011$} & \multicolumn{2}{|c|}{$7 / 22 / 2011$} & \multicolumn{2}{|c|}{$7 / 29 / 2011$} & \multicolumn{2}{|c|}{$8 / 5 / 2011$} & \multicolumn{2}{|c|}{$8 / 12 / 2011$} & \multicolumn{2}{|c|}{$8 / 19 / 2011$} & \multicolumn{2}{|c|}{$8 / 26 / 2011$} \\
\hline & & $\begin{array}{c}7 d \\
\text { Avg } \\
\end{array}$ & $\begin{array}{l}\text { Week } \\
\text { Max }\end{array}$ & $\begin{array}{c}7 d \\
A v g \\
\end{array}$ & $\begin{array}{l}\text { Week } \\
\text { Max }\end{array}$ & $\begin{array}{c}7 d \\
A v g \\
\end{array}$ & $\begin{array}{l}\text { Week } \\
\text { Max }\end{array}$ & $\begin{array}{c}7 d \\
\text { Avg } \\
\end{array}$ & $\begin{array}{l}\text { Week } \\
\text { Max }\end{array}$ & $\begin{array}{c}7 d \\
A v g \\
\end{array}$ & $\begin{array}{l}\text { Week } \\
\text { Max }\end{array}$ & $\begin{array}{c}7 d \\
A v g \\
\end{array}$ & $\begin{array}{c}\text { Week } \\
\text { Max }\end{array}$ & $\begin{array}{c}7 d \\
A v g \\
\end{array}$ & $\begin{array}{l}\text { Week } \\
\text { Max }\end{array}$ & $\begin{array}{c}7 d \\
A v g \\
\end{array}$ & $\begin{array}{l}\text { Week } \\
\text { Max }\end{array}$ & $\begin{array}{c}7 d \\
A v g \\
\end{array}$ & $\begin{array}{c}\text { Week } \\
\text { Max }\end{array}$ \\
\hline \multirow{3}{*}{$\begin{array}{c}\text { East } \\
\text { Walker }\end{array}$} & 225.4 & 18.8 & 25.1 & 19.0 & 25.0 & 21.0 & 24.6 & 21.2 & 24.9 & 21.1 & 24.4 & 21.4 & 23.9 & 20.0 & 23.7 & 20.2 & 23.3 & 20.2 & 21.8 \\
\hline & 135.6 & 22.4 & 25.1 & 20.6 & 26.4 & 21.8 & 25.7 & 23.2 & 25.1 & 22.6 & 24.4 & 22.5 & 24.9 & 21.5 & 24.2 & 22.6 & 23.1 & 21.5 & 22.3 \\
\hline & 121.5 & 22.8 & 25.0 & 20.8 & 26.5 & 21.8 & 26.4 & 23.3 & 25.2 & 22.7 & 24.8 & 22.6 & 25.4 & 21.6 & 24.6 & 22.8 & 23.5 & 21.6 & 22.6 \\
\hline \multirow{5}{*}{ Walker } & 94.0 & 22.6 & 25.0 & 21.8 & 26.8 & 22.2 & 26.8 & 23.7 & 27.0 & 23.3 & 26.5 & 23.0 & 27.1 & 21.9 & 26.9 & 23.1 & 25.3 & 21.9 & 23.7 \\
\hline & 87.6 & 22.7 & 25.3 & 21.8 & 27.0 & 22.2 & 26.9 & 23.7 & 26.2 & 23.3 & 26.0 & 22.8 & 26.8 & 21.6 & 25.7 & 22.8 & 24.8 & 21.6 & 23.4 \\
\hline & 77.5 & 22.8 & 25.2 & 21.8 & 26.7 & 22.2 & 26.2 & 23.7 & 26.0 & 23.3 & 24.4 & 22.8 & 25.2 & 21.3 & 24.8 & 22.5 & 23.3 & 21.4 & 22.2 \\
\hline & 46.1 & 22.8 & 22.4 & 22.6 & 23.7 & 21.6 & 23.9 & 23.1 & 24.0 & 23.4 & 23.8 & 23.4 & 23.9 & 22.7 & 23.8 & 23.2 & 22.7 & 23.1 & 21.9 \\
\hline & 2.7 & 23.4 & 23.1 & 22.6 & 26.4 & 22.0 & 28.2 & 23.5 & 25.8 & 23.2 & 26.0 & 23.2 & 26.8 & 22.0 & 25.6 & 23.4 & 24.7 & 22.2 & 23.3 \\
\hline \multirow{3}{*}{$\begin{array}{c}\text { West } \\
\text { Walker }\end{array}$} & 39.7 & 20.8 & 24.6 & 22.9 & 25.3 & 22.4 & 25.4 & 23.7 & 25.4 & 23.6 & 24.7 & 23.5 & 23.6 & 20.5 & 23.7 & 21.1 & 23.3 & 21.4 & 22.2 \\
\hline & 10.1 & 21.4 & 24.8 & 22.4 & 26.3 & 22.3 & 25.8 & 23.8 & 26.0 & 23.5 & 24.8 & 23.3 & 25.3 & 21.3 & 25.3 & 22.1 & 23.3 & 21.7 & 22.3 \\
\hline & $\underset{\rightarrow}{\operatorname{Max}}$ & 23.4 & 25.3 & 22.9 & 27.0 & 22.4 & 28.2 & 23.8 & 27.0 & 23.6 & 26.5 & 23.5 & 27.1 & 22.7 & 26.9 & 23.4 & 25.3 & 23.1 & 23.7 \\
\hline & River & \multicolumn{2}{|c|}{$7 / 1 / 2012$} & \multicolumn{2}{|c|}{$7 / 8 / 2012$} & \multicolumn{2}{|c|}{$7 / 15 / 2012$} & \multicolumn{2}{|c|}{$7 / 22 / 2012$} & \multicolumn{2}{|c|}{$7 / 29 / 2012$} & \multicolumn{2}{|c|}{ 8/5/2012 } & \multicolumn{2}{|c|}{$8 / 12 / 2012$} & \multicolumn{2}{|c|}{$8 / 19 / 2012$} & \multicolumn{2}{|c|}{$8 / 26 / 2012$} \\
\hline & $\mathrm{km}$ & $\begin{array}{c}7 d \\
A v g \\
\end{array}$ & $\begin{array}{l}\text { Week } \\
\text { Max }\end{array}$ & $\begin{array}{c}7 d \\
A v g\end{array}$ & $\begin{array}{l}\text { Week } \\
\text { Max }\end{array}$ & $\begin{array}{c}7 d \\
A v g\end{array}$ & $\begin{array}{l}\text { Week } \\
\text { Max }\end{array}$ & $\begin{array}{c}7 d \\
\text { Avg }\end{array}$ & $\begin{array}{l}\text { Week } \\
\text { Max }\end{array}$ & $\begin{array}{c}7 d \\
A v g\end{array}$ & $\begin{array}{l}\text { Week } \\
\text { Max }\end{array}$ & $\begin{array}{c}7 d \\
A v g\end{array}$ & $\begin{array}{c}\text { Week } \\
\text { Max }\end{array}$ & $\begin{array}{c}7 d \\
A v g\end{array}$ & $\begin{array}{l}\text { Week } \\
\text { Max }\end{array}$ & $\begin{array}{c}7 d \\
\text { Avg }\end{array}$ & $\begin{array}{l}\text { Week } \\
\text { Max }\end{array}$ & $\begin{array}{c}7 d \\
A v g\end{array}$ & $\begin{array}{c}\text { Week } \\
\text { Max }\end{array}$ \\
\hline \multirow{3}{*}{$\begin{array}{c}\text { East } \\
\text { Walker }\end{array}$} & 225.4 & 19.7 & 24.5 & 20.5 & 25.2 & 20.3 & 25.8 & 21.7 & 26.1 & 21.6 & 26.2 & 21.9 & 26.1 & 21.2 & 25.7 & 21.7 & 25.8 & 20.3 & 24.6 \\
\hline & 135.6 & 22.8 & 26.2 & 23.1 & 26.5 & 20.0 & 24.8 & 23.6 & 26.7 & 23.5 & 26.8 & 23.5 & 26.5 & 21.9 & 25.2 & 22.4 & 25.5 & 19.8 & 23.5 \\
\hline & 121.5 & 23.0 & 28.1 & 23.2 & 28.2 & 20.1 & 26.4 & 23.7 & 27.6 & 23.6 & 28.5 & 23.7 & 27.6 & 21.9 & 26.2 & 22.5 & 26.5 & 19.8 & 24.4 \\
\hline \multirow{5}{*}{ Walker } & 94.0 & 23.2 & 28.4 & 23.5 & 28.5 & 20.5 & 27.4 & 23.9 & 28.5 & 23.9 & 31.2 & 24.1 & 28.9 & 22.2 & 26.5 & 22.9 & 27.0 & 19.9 & 24.8 \\
\hline & 87.6 & 23.3 & 28.4 & 23.5 & 28.4 & 20.4 & 27.2 & 23.9 & 28.5 & 23.8 & 30.4 & 24.1 & 28.6 & 22.1 & 26.5 & 22.9 & 26.9 & 19.8 & 24.3 \\
\hline & 77.5 & 23.2 & 27.0 & 23.4 & 27.0 & 20.2 & 25.8 & 23.7 & 27.5 & 23.5 & 28.7 & 23.9 & 27.4 & 22.1 & 26.3 & 22.8 & 25.9 & 19.8 & 23.6 \\
\hline & 46.1 & 22.2 & 23.4 & 23.4 & 24.4 & 22.1 & 24.0 & 22.6 & 24.1 & 23.7 & 24.6 & 23.9 & 24.9 & 23.4 & 24.7 & 22.9 & 23.8 & 21.9 & 23.4 \\
\hline & 2.7 & 23.4 & 30.0 & 23.4 & 29.9 & 20.4 & 28.4 & 24.0 & 29.9 & 23.8 & 30.6 & 24.1 & 30.0 & 21.9 & 28.0 & 22.9 & 28.8 & 19.8 & 25.7 \\
\hline \multirow{3}{*}{$\begin{array}{c}\text { West } \\
\text { Walker }\end{array}$} & 39.7 & 20.8 & 24.9 & 23.2 & 25.5 & 21.6 & 25.0 & 23.7 & 26.3 & 23.7 & 26.3 & 23.8 & 26.4 & 23.1 & 25.8 & 23.5 & 25.9 & 21.6 & 24.2 \\
\hline & 10.1 & 22.3 & 26.2 & 23.4 & 26.6 & 20.9 & 26.1 & 23.9 & 27.4 & 23.9 & 27.7 & 24.0 & 27.1 & 22.5 & 25.8 & 23.2 & 26.4 & 20.7 & 24.2 \\
\hline & $\underset{\rightarrow}{\operatorname{Max}}$ & 23.4 & 30.0 & 23.5 & 29.9 & 22.1 & 28.4 & 24.0 & 29.9 & 23.9 & 31.2 & 24.1 & 30.0 & 23.4 & 28.0 & 23.5 & 28.8 & 21.9 & 25.7 \\
\hline
\end{tabular}




\subsection{Existing Transfers}

A handful of environmental water transfers have been negotiated and purchased in the Walker Basin, which change with hydrological conditions (wet versus dry years) as they are tied to water rights with varying seniority. Average daily instream flow from existing environmental water transfers increased by $0.81 \mathrm{cms}$ and $0.09 \mathrm{cms}$ for years 2011 and 2012, respectively (Borgen, pers. comm. 2014). Existing water transfers at Bridgeport, BNGHH, SSWJD, COLONY and GAGE did not noticeably reduce stream temperatures below the 7 day average thermal limit during wet or dry years. However, environmental water transfer effects were more pronounced for maximum daily temperatures. The largest change in maximum daily temperature was $2.72{ }^{\circ} \mathrm{C}$ on $8 / 2 / 2011$, reducing stream temperature from $29.68^{\circ} \mathrm{C}$ to $26.96{ }^{\circ} \mathrm{C}$, and $1.09{ }^{\circ} \mathrm{C}$ on $8 / 6 / 2012$, reducing stream temperature from $29.95^{\circ} \mathrm{C}$ to $28.86^{\circ} \mathrm{C}$, near river kilometer 2.69 by the mouth of Walker Lake (Figure 4-5; Figure 4-6). Due to the above average streamflow in the wet year 2011, temperature fluctuations can be seen in the model instability when encountering Weber Reservoir at around rkm 70 through 50 in Figure 46. Additionally, the stark drop in stream temperatures at the same river kilometers in the wet year 2012 can be attributed to the relatively large volume of water in Weber Reservoir, clearly illustrating the cooling properties of increasing thermal mass (Figure 4$6)$. 


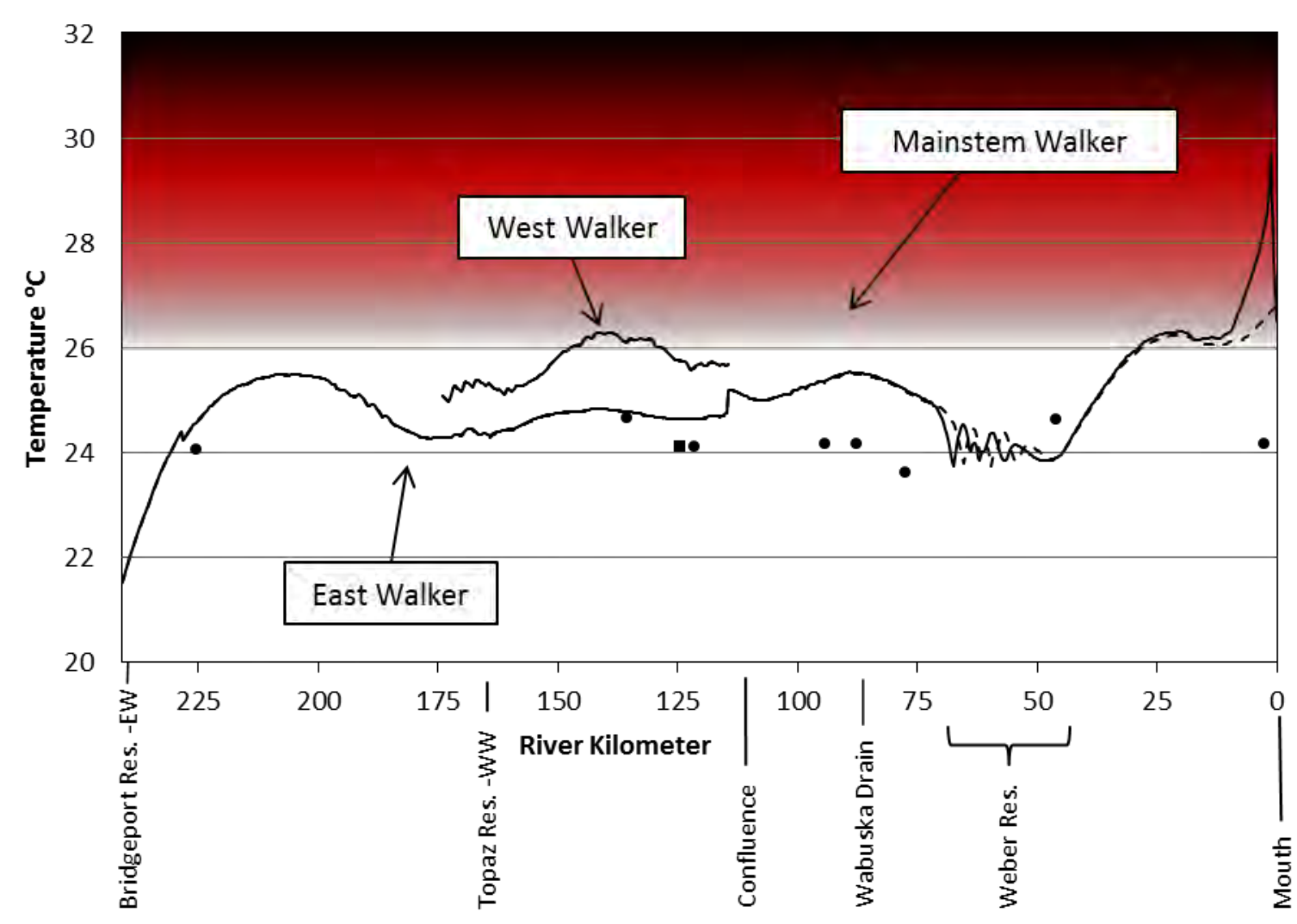

Figure 4-5: Modeled daily maximum stream temperature longitudinal profile on 8/2/2011 for Historical Conditions (solid line) and Existing Transfers (dashed line). Points represent measured daily maximum temperatures on the East Walker, mainstem (circles), and West Walker (square) Rivers. Red shaded gradient represents range of $28^{\circ} \mathrm{C}$ acute thermal limit for LCT.

\subsection{Comparison of Environmental Water Transfer Scenarios}

Daily environmental water transfers of $0.14,0.25,0.71$, and $1.41 \mathrm{cms}$ during irrigation season did not significantly cool 7 day average stream temperatures during 2011 or 2012, respectively (Table 4-4). Environmental water transfers did not change 7 day average stream temperatures because nightly low temperatures warmed while daily high temperatures cooled (Figure 4-7; Figure 4-8). This trend was consistent for all environmental water transfer model simulations in the Walker Basin. Environmental water transfers raise the thermal mass of the river, so that stream temperatures require 
more energy to warm and thus heat and cool more slowly than with low flow conditions. Daily maximum stream temperatures were again reduced with environmental water transfers, especially in 2012, a dry year. In 2012, daily maximum stream temperatures dropped by nearly $1^{\circ} \mathrm{C}, 1.25^{\circ} \mathrm{C}, 2^{\circ} \mathrm{C}$, and $2.5^{\circ} \mathrm{C}$ with water transfers of $0.14,0.25,0.71$, and $1.41 \mathrm{cms}$, respectively. Differences in the intensity of changes between the two years are explained by the large difference in streamflow (i.e. thermal mass) between wet and dry years.

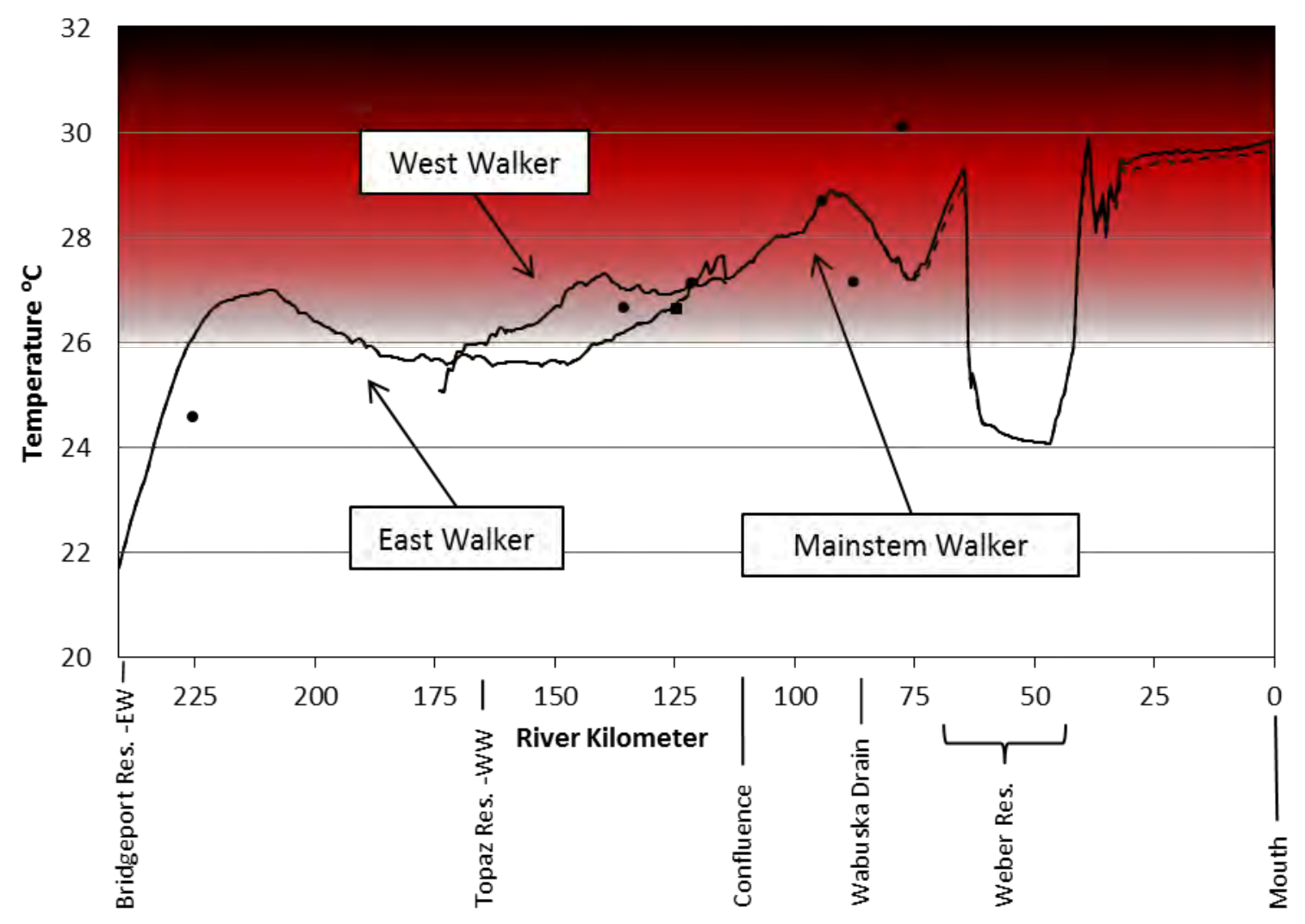

Figure 4-6: Modeled daily maximum stream temperature longitudinal profile on 8/2/2012 for Historical Conditions (solid line) and Existing Transfers (dashed line). Points represent measured daily maximum temperatures on the East Walker, mainstem (circles), and West Walker (square) Rivers. Red shaded gradient represents range of $28^{\circ} \mathrm{C}$ acute thermal limit for LCT. 


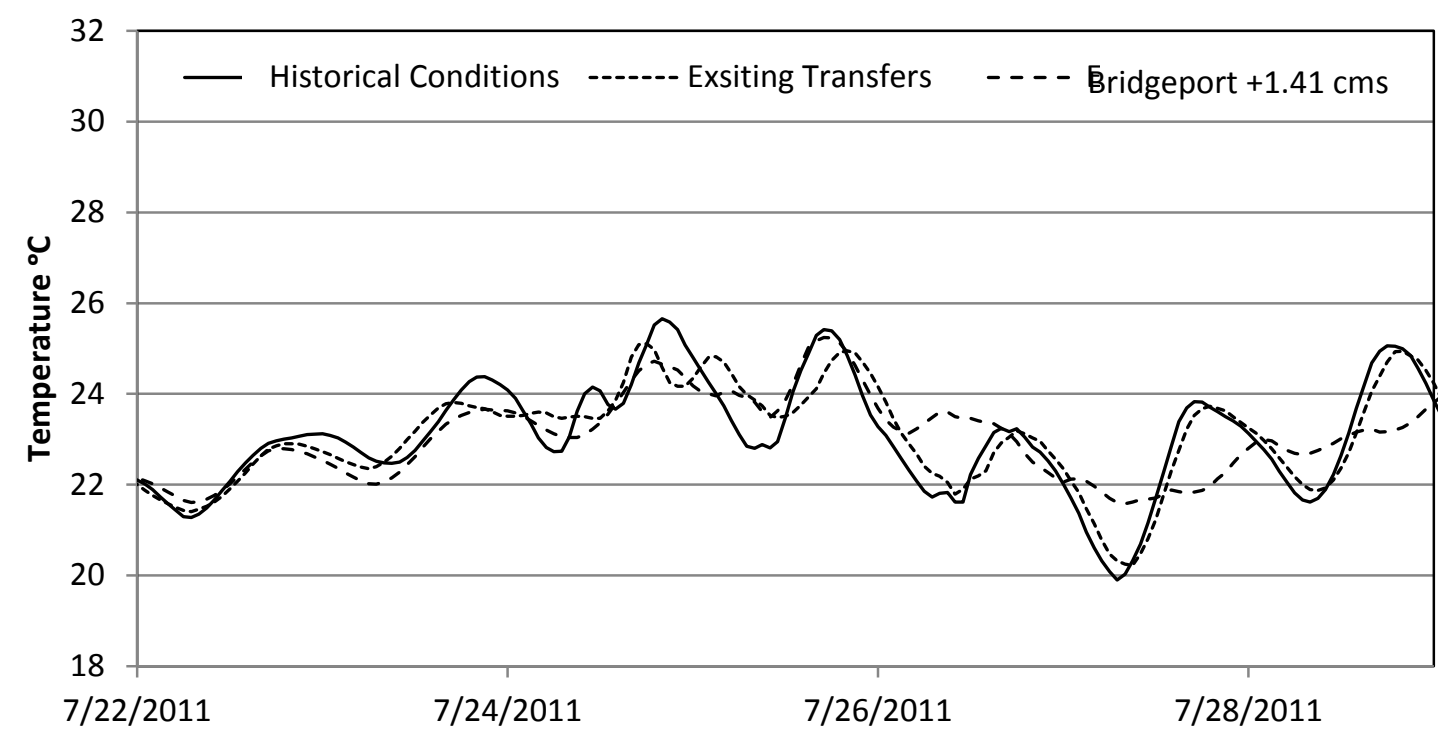

Figure 4-7: Hourly stream temperatures at river km 2.69 for week 7/22/2011.

The largest maximum daily stream temperature changes occurred with daily 1.41 cms instream flow increases at Topaz and Bridgeport Reservoirs. Modeling suggests stream temperatures would be reduced by $0.53{ }^{\circ} \mathrm{C}$ in the $65 \mathrm{rkms}$ between Weber Reservoir to the mouth of Walker Lake in 2011 from increased Topaz Reservoir streamflow and $3.03{ }^{\circ} \mathrm{C}$ in 2012 from increased Bridgeport Reservoir streamflow (Table 4-4). Results also indicate that environmental water transfers have a greater habitat benefit in dry years. Wet years have more streamflow so environmental water purchases have less of an effect on stream temperatures.

Diversions were reduced to zero at individual diversion locations for the Diversion Off scenarios, representing maximum environmental water transfers at each individual site. With these runs, more substantial changes of $1.99^{\circ} \mathrm{C}, 1.80^{\circ} \mathrm{C}$, and 2.39 ${ }^{\circ} \mathrm{C}$ occurred at large diversions such as BNGHH, MCCAMP, and COLONY downstream 
of Weber Reservoir in dry year 2012 (Table 4-4). Total amounts of instream flow added to the river (not diverted) are summarized in Table 4-5.

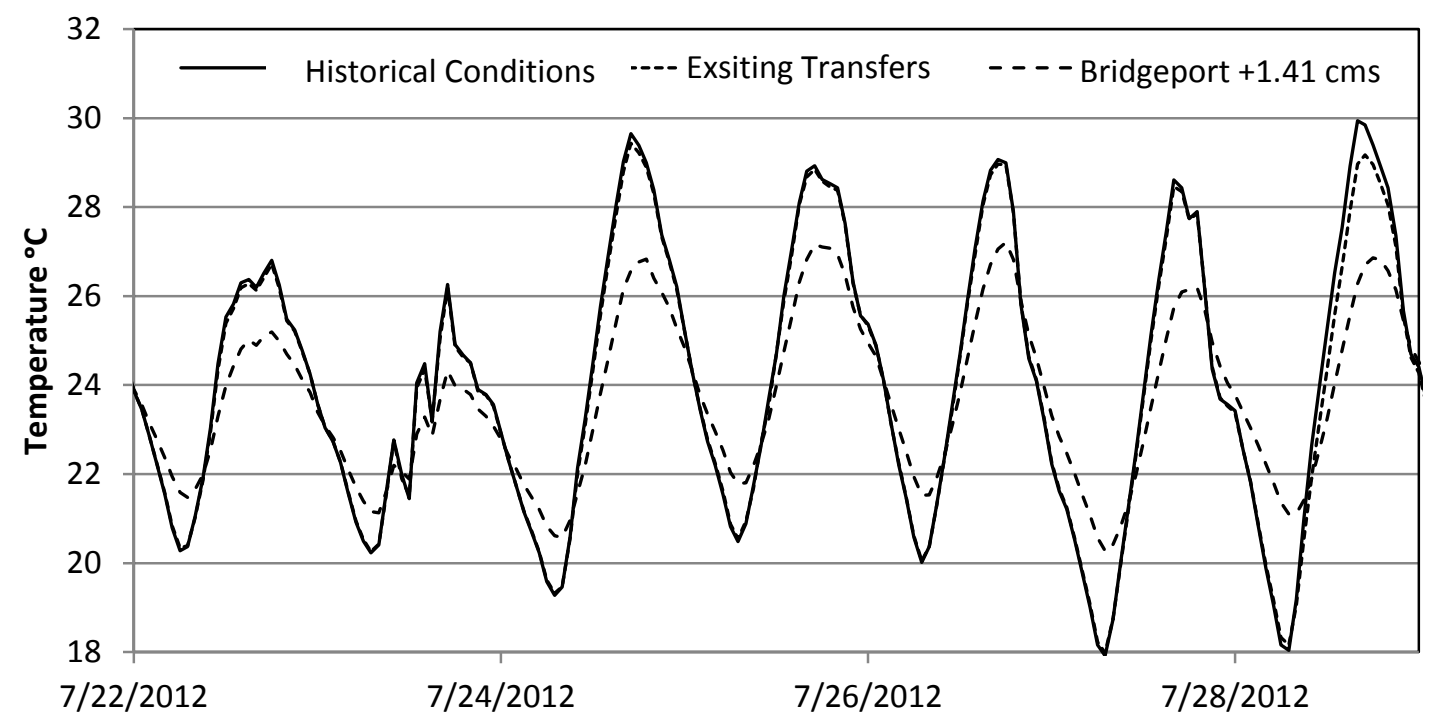

Figure 4-8: Hourly stream temperatures at river km 2.69 for week 7/22/2012.

No Diversion conditions were estimated for both years, where diversions at all sites were set to zero. These runs are helpful to bracket the range of possibilities for environmental water transfer effects on stream temperatures. The total volume of water not diverted during irrigation season for these runs was $2686 \mathrm{~m}^{3}$ for 2011 and $1417 \mathrm{~m}^{3}$ for 2012. These runs reduced simulated daily maximum temperatures by $2.01{ }^{\circ} \mathrm{C}$ in 2011 and $3.28{ }^{\circ} \mathrm{C}$ in 2012 near the mouth of Walker Lake. With this alternative, the largest stream temperature reductions occurred above Weber Reservoir near Mason Valley Wildlife Refuge at river kilometer 77.52 , but still failed to adequately reduce 7 day average stream temperatures during thermally limited weeks of July 1 through August 26 from the confluence of the East and West Walker Rivers to Weber Reservoir (Table 4-4). 
No Diversions to Walker Lake represents the best case scenario for Walker River (and Walker Lake) restoration.

Table 4-4. Maximum change in 7 day average (chronic) and daily maximum (acute) stream temperatures by model run for 2011 and 2012 from July 1-August 26.

\begin{tabular}{|c|c|c|c|c|c|c|c|c|c|c|}
\hline \multirow[b]{2}{*}{2011 Runs } & \multicolumn{2}{|c|}{$0.14 \mathrm{cms}$} & \multicolumn{2}{|c|}{$0.28 \mathrm{cms}$} & \multicolumn{2}{|c|}{$0.71 \mathrm{cms}$} & \multicolumn{2}{|c|}{$1.41 \mathrm{cms}$} & \multicolumn{2}{|c|}{$\begin{array}{c}\text { Diversion } \\
\text { Off }\end{array}$} \\
\hline & $\begin{array}{c}7 d \\
A v g\end{array}$ & $\begin{array}{l}\text { Daily } \\
\text { Max }\end{array}$ & $\begin{array}{c}7 d \\
A v g\end{array}$ & $\begin{array}{l}\text { Daily } \\
\text { Max }\end{array}$ & $\begin{array}{c}7 d \\
\text { Avg }\end{array}$ & $\begin{array}{l}\text { Daily } \\
\text { Max }\end{array}$ & $\begin{array}{c}7 d \\
A v g\end{array}$ & $\begin{array}{l}\text { Daily } \\
\text { Max }\end{array}$ & $\begin{array}{c}7 d \\
A v g\end{array}$ & $\begin{array}{l}\text { Daily } \\
\text { Max }\end{array}$ \\
\hline Bridgeport & 0.00 & 0.10 & 0.00 & 0.16 & 0.01 & 0.33 & 0.01 & 0.49 & - & - \\
\hline Topaz & - & - & - & - & 0.01 & 0.36 & 0.01 & 0.53 & - & - \\
\hline BNGHH & 0.00 & 0.10 & 0.01 & 0.16 & - & - & - & - & 0.01 & 0.31 \\
\hline FOX & 0.00 & 0.10 & 0.01 & 0.16 & - & - & - & - & 0.01 & 0.53 \\
\hline MCCAMP & 0.00 & 0.10 & 0.01 & 0.16 & - & - & - & - & 0.01 & 0.76 \\
\hline SSWJD & 0.01 & 0.10 & 0.01 & 0.16 & 0.01 & 0.28 & 0.01 & 0.31 & 0.00 & 0.45 \\
\hline CANAL & 0.00 & 0.00 & 0.00 & 0.01 & - & - & - & - & 0.01 & 0.02 \\
\hline SARONI & 0.00 & 0.10 & 0.01 & 0.16 & - & - & - & - & 0.01 & 0.25 \\
\hline COLONY & 0.00 & 0.10 & 0.01 & 0.16 & - & - & - & - & 0.01 & 0.47 \\
\hline GAGE & 0.00 & 0.10 & 0.01 & 0.16 & - & - & - & - & 0.01 & 0.29 \\
\hline TUNNEL & 0.01 & 0.10 & 0.01 & 0.16 & - & - & - & - & 0.01 & 0.42 \\
\hline No Diversion & - & - & - & - & - & - & - & - & 0.09 & 2.01 \\
\hline 2012 Runs & $\begin{array}{c}7 d \\
A v g\end{array}$ & $\begin{array}{l}\text { Daily } \\
\text { Max }\end{array}$ & $\begin{array}{c}7 d \\
A v g\end{array}$ & $\begin{array}{l}\text { Daily } \\
\text { Max }\end{array}$ & $\begin{array}{c}7 d \\
A v g\end{array}$ & $\begin{array}{l}\text { Daily } \\
\text { Max }\end{array}$ & $\begin{array}{c}7 d \\
A v g\end{array}$ & $\begin{array}{l}\text { Daily } \\
\text { Max }\end{array}$ & $\begin{array}{c}7 d \\
A v g\end{array}$ & $\begin{array}{l}\text { Daily } \\
\text { Max }\end{array}$ \\
\hline Bridgeport & 0.02 & 0.96 & 0.04 & 1.27 & 0.08 & 2.29 & 0.25 & 3.03 & - & - \\
\hline Topaz & - & - & - & - & 0.11 & 2.76 & 0.17 & 2.95 & - & - \\
\hline BNGHH & 0.02 & 0.96 & 0.04 & 1.27 & - & - & - & - & 0.08 & 1.99 \\
\hline FOX & 0.02 & 0.96 & 0.04 & 1.26 & - & - & - & - & 0.07 & 1.70 \\
\hline MCCAMP & 0.02 & 0.96 & 0.04 & 1.27 & - & - & - & - & 0.10 & 1.80 \\
\hline SSWJD & 0.02 & 0.96 & 0.04 & 1.25 & 0.08 & 1.63 & 0.13 & 2.36 & 0.09 & 1.63 \\
\hline CANAL & 0.01 & 0.87 & 0.04 & 1.18 & - & - & - & - & 0.07 & 1.40 \\
\hline SARONI & 0.02 & 0.96 & 0.04 & 1.22 & - & - & - & - & 0.06 & 1.35 \\
\hline COLONY & 0.02 & 0.96 & 0.04 & 1.23 & - & - & - & - & 0.15 & 2.39 \\
\hline GAGE & 0.02 & 0.96 & 0.04 & 1.24 & - & - & - & - & 0.10 & 1.82 \\
\hline TUNNEL & 0.02 & 0.96 & 0.04 & 1.25 & - & - & - & - & 0.06 & 1.62 \\
\hline No Diversion & - & - & - & - & - & - & - & - & 0.26 & 3.28 \\
\hline
\end{tabular}


Table 4-5: Total irrigation season water not diverted by model run in cms. Columns in grey are single runs (i.e. all cells run together at one time).

\begin{tabular}{|c|c|c|c|c|c|c|c|}
\hline 2011 Runs & $\begin{array}{c}\text { Existing } \\
\text { Transfers }\end{array}$ & $\begin{array}{l}0.14 \mathrm{cms} \\
\text { Additions }\end{array}$ & $\begin{array}{l}0.28 \mathrm{cms} \\
\text { Additions }\end{array}$ & $\begin{array}{c}0.71 \mathrm{cms} \\
\text { Additions }\end{array}$ & $\begin{array}{c}1.41 \mathrm{cms} \\
\text { Additions }\end{array}$ & $\begin{array}{c}\text { Diversion } \\
\text { Off }\end{array}$ & $\begin{array}{c}\text { No } \\
\text { Diversions }\end{array}$ \\
\hline Bridgeport & $7.87 E+08$ & $7.34 \mathrm{E}+08$ & $1.47 E+09$ & $3.67 E+09$ & $7.34 \mathrm{E}+09$ & - & - \\
\hline Topaz & - & - & - & $3.67 E+09$ & $7.34 \mathrm{E}+09$ & - & - \\
\hline BNGHH & $1.82 \mathrm{E}+08$ & $6.63 E+08$ & $1.29 E+09$ & - & - & $3.63 E+09$ & $3.63 E+09$ \\
\hline FOX & - & $6.76 \mathrm{E}+08$ & $1.34 \mathrm{E}+09$ & - & - & $8.90 E+09$ & $8.90 E+09$ \\
\hline MCCAMP & - & $6.24 \mathrm{E}+08$ & $1.24 \mathrm{E}+09$ & - & - & $1.05 E+10$ & $1.05 E+10$ \\
\hline SSWJD & $1.71 \mathrm{E}+09$ & $5.62 E+08$ & $1.09 E+09$ & $2.54 \mathrm{E}+09$ & $4.29 E+09$ & $5.53 E+09$ & $5.53 E+09$ \\
\hline CANAL & - & $2.89 E+08$ & $5.70 \mathrm{E}+08$ & - & - & $2.36 \mathrm{E}+09$ & $2.36 \mathrm{E}+09$ \\
\hline SARONI & - & $6.60 \mathrm{E}+08$ & $1.27 E+09$ & - & - & $2.91 E+09$ & $2.91 E+09$ \\
\hline COLONY & $1.12 \mathrm{E}+08$ & $6.93 E+08$ & $1.35 E+09$ & - & - & $1.02 \mathrm{E}+10$ & $1.02 \mathrm{E}+10$ \\
\hline GAGE & $7.03 E+08$ & $6.28 \mathrm{E}+08$ & $1.24 \mathrm{E}+09$ & - & - & $4.55 E+09$ & $4.55 E+09$ \\
\hline TUNNEL & - & $5.71 E+08$ & $1.13 E+09$ & - & - & $8.26 \mathrm{E}+09$ & $8.26 E+09$ \\
\hline 2012 Runs & $\begin{array}{c}\text { Existing } \\
\text { Transfers }\end{array}$ & $\begin{array}{l}0.14 \mathrm{cms} \\
\text { Additions }\end{array}$ & $\begin{array}{c}0.28 \mathrm{cms} \\
\text { Additions }\end{array}$ & $\begin{array}{c}0.71 \mathrm{cms} \\
\text { Additions }\end{array}$ & $\begin{array}{c}1.41 \mathrm{cms} \\
\text { Additions }\end{array}$ & $\begin{array}{c}\text { Diversion } \\
\text { Off }\end{array}$ & $\begin{array}{c}\text { No } \\
\text { Diversions }\end{array}$ \\
\hline Bridgeport & $1.11 \mathrm{E}+08$ & $7.31 \mathrm{E}+08$ & $1.46 \mathrm{E}+09$ & $3.66 \mathrm{E}+09$ & $7.31 E+09$ & - & - \\
\hline Topaz & - & - & - & $3.66 E+09$ & $7.31 E+09$ & - & - \\
\hline BNGHH & 0 & $7.00 \mathrm{E}+08$ & $1.38 \mathrm{E}+09$ & - & - & $3.82 E+09$ & $3.82 E+09$ \\
\hline FOX & - & $6.89 E+08$ & $1.31 \mathrm{E}+09$ & - & - & $2.06 \mathrm{E}+09$ & $2.06 \mathrm{E}+09$ \\
\hline MCCAMP & - & $7.30 \mathrm{E}+08$ & $1.44 \mathrm{E}+09$ & - & - & $6.26 E+09$ & $6.26 \mathrm{E}+09$ \\
\hline SSWJD & $1.56 \mathrm{E}+08$ & $7.25 E+08$ & $1.43 E+09$ & $3.01 E+09$ & $3.87 E+09$ & $4.24 \mathrm{E}+09$ & $4.24 \mathrm{E}+09$ \\
\hline CANAL & - & $4.99 E+08$ & $9.87 E+08$ & - & - & $3.53 E+09$ & $3.53 E+09$ \\
\hline SARONI & - & $5.86 \mathrm{E}+08$ & $9.94 \mathrm{E}+08$ & - & - & $1.23 E+09$ & $1.23 \mathrm{E}+09$ \\
\hline COLONY & $4.02 E+06$ & $6.54 \mathrm{E}+08$ & $1.27 E+09$ & - & - & $4.34 \mathrm{E}+09$ & $4.34 \mathrm{E}+09$ \\
\hline GAGE & $1.96 \mathrm{E}+08$ & $6.31 E+08$ & $1.15 E+09$ & - & - & $2.03 E+09$ & $2.03 E+09$ \\
\hline TUNNEL & - & $7.08 \mathrm{E}+08$ & $1.30 E+09$ & - & - & $2.48 \mathrm{E}+09$ & $2.48 \mathrm{E}+09$ \\
\hline
\end{tabular}

Finally, two sensitivity analyses were conducted. A depth sensitivity analysis was done to examine any effects if a deeper river, where twenty percent was added to all center depths of $0.94 \mathrm{~m}$, for a total of $1.18 \mathrm{~m}$ below water surface. A shading analysis was also conducted to determine shading sensitivity. In this case, ten sites were chosen throughout the basin with no riparian shading (100\% solar transmittance) and increased 
to the willow category of most shading ( $9 \%$ solar transmittance). The ten shading sites were river kilometers $140.04,84.23$, and 75.05 on the East Walker; 25.68 and 6.27 on the West Walker; 58.61, 54.43, 48.17, 28.62, and 1.67 on the mainstem Walker River. The results from these analyses indicated very little to no change (figures in Appendix B). 


\section{CHAPTER 5}

\section{DISCUSSION}

With Historical Conditions, much of the Walker River is thermally limited in July and August, including the lower reaches of the East Walker River from approximately river kilometer 160 to Weber Reservoir at river kilometer 65, the lowest reaches of the mainstem Walker from river kilometer 25 to Walker Lake, and most of the West Walker River. In general, neither existing environmental water transfers nor larger water transfers of $1.41 \mathrm{cms}$ or greater reduced 7 day average stream temperatures considerably in either year where the river is thermally limited because daily maximum temperatures were reduced as daily minimum temperatures increased. In fact, even the No Diversions alternative did not reduce 7 day average stream temperatures below the confluence of the mainstem or the West Walker River (Table 4-4).

However, environmental water transfers reduced maximum daily temperatures at all locations during summer (Table 4-4). This was most pronounced downstream of Weber Reservoir and especially in dry year 2012, when additional streamflow reduced daily maximum stream temperatures by almost $1{ }^{\circ} \mathrm{C}$ with only $0.14 \mathrm{cms}$ transferred from agricultural users to instream flows near the mouth of Walker Lake. Acute maximum stream temperature reductions could positively affect aquatic habitat, especially where connectivity of thermal refugia improves, such as the 65 river km below Weber Reservoir to Walker Lake, provided purchased water is released through Weber Reservoir (Figure 5-1). Determining whether acute stream temperature thresholds (greater than $28^{\circ} \mathrm{C}$ for 2 hours) or chronic stream temperatures (average weekly stream temperature exceeds 
$24^{\circ} \mathrm{C}$ ) most limit LCT warrants additional research to better focus thermal habitat restoration for cold water fishes, although it is outside the scope of this study.

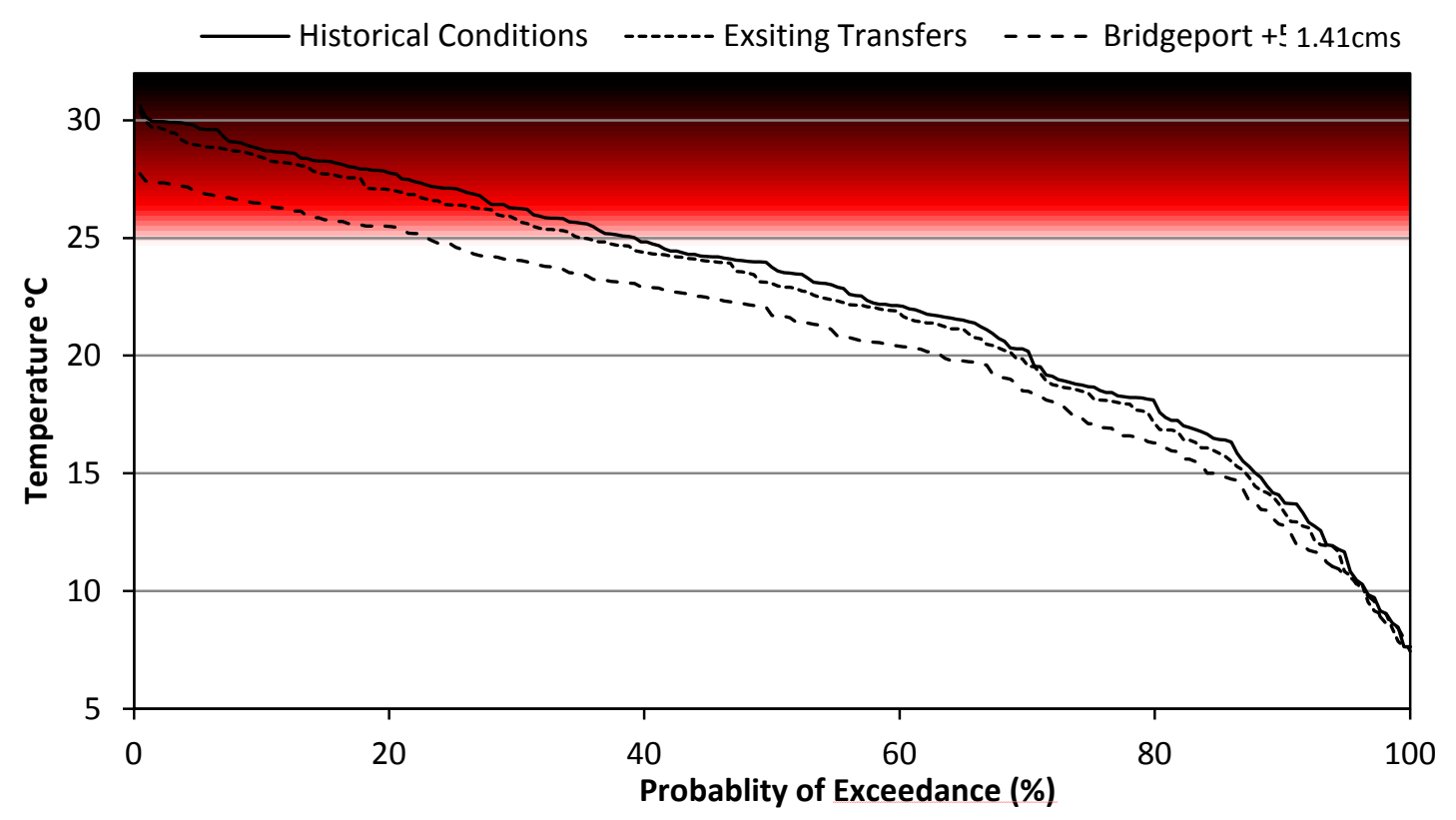

Figure 5-1: Probability of exceedance for daily maximum stream temperatures during irrigation season, $2012\left(\mathrm{n}=245\right.$ days) at river $\mathrm{km} 2.69$. Red shading indicates $28^{\circ} \mathrm{C}$ acute thermal limit for LCT.

The 2012 historical conditions simulation indicates the East Walker River is not thermally limiting for LCT until approximately river kilometer 160 during irrigation season. This is supported by measured stream temperatures (Figure 2-2; Figure 2-3). Bridgeport Reservoir on the East Walker River is located at an elevation of $1950 \mathrm{~m}$, approximately $500 \mathrm{~m}$ higher than Topaz Reservoir. East Walker River flows through a canyon with topographical and riparian shading, which maintains cool reservoir release temperatures in this reach. Further, Sweetwater Creek, a small tributary in the upper reaches of East Walker River, contributes an average annual flow of $0.16 \mathrm{cms}$ of cool water year round (average annual temperature is $10^{\circ} \mathrm{C}$ ). Thus, the East Walker River provides thermal refugia for LCT and other trout species. This indicates that East Walker 
River is a promising location for future restoration targeting riparian vegetation or stream channel improvements to further improve currently suitable thermal habitat.

The West Walker River averages $2{ }^{\circ} \mathrm{C}$ warmer annually than the East Walker River. The West Walker River is half the length of the East Walker River, with a shorter course to the confluence. This reduces heating from insolation; however, releases from Topaz Reservoir are warmer than those from Bridgeport Reservoir (Figure 5-2) and there are no measurable cool water contributions from tributaries. Therefore, the West Walker River probably rarely provides suitable LCT habitat during July and August with Historical Conditions.

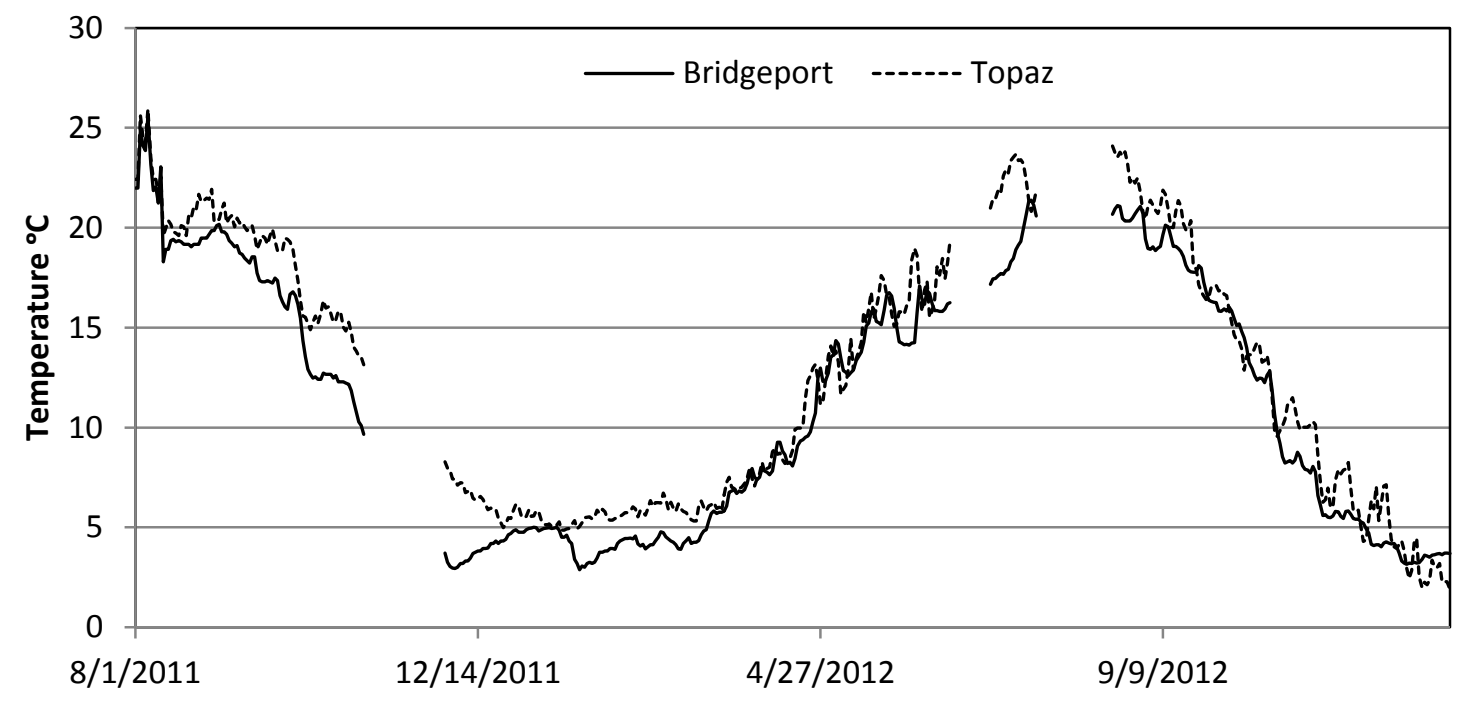

Figure 5-2: Measured average daily reservoir release temperatures from Bridgeport and Topaz Reservoirs.

Determining which water transfer alternatives most reduce stream temperatures in the Walker River was a top priority of this research. Less than 5 days per year and less than 5 river kilometers between Weber Reservoir and Walker Lake exceed acute thermal limits in wet year 2011. However, in dry years like 2012, stream temperatures exceeded 
$28^{\circ} \mathrm{C}$ over 35 days and for up to 70 river kilometers (Figure 5-3; Figure 5-4). Existing environmental water transfers effectively reduced the number of days and river length that maximum stream temperatures exceed $28^{\circ} \mathrm{C}$ during dry years. Environmental water transfers that allow substantial releases from Topaz or Bridgeport Reservoirs (for example releases of $1.41 \mathrm{cms}$ ) were promising for thermal management, with releases from Bridgeport Reservoir on the East Walker River providing larger reductions in stream temperature over a longer distance. Modeling suggested that instream flow increases of 0.71 or $1.41 \mathrm{cms}$ at the Sab, Sciariani, West-Hyland, Joggles, and Dairy (SSWDJ) Diversion at river km 61.27 could add approximately 20 days and an average of 40 river kilometers where stream temperatures do not exceed $28^{\circ} \mathrm{C}$. This shows that environmental water transfers can improve thermal habitat in dry years.

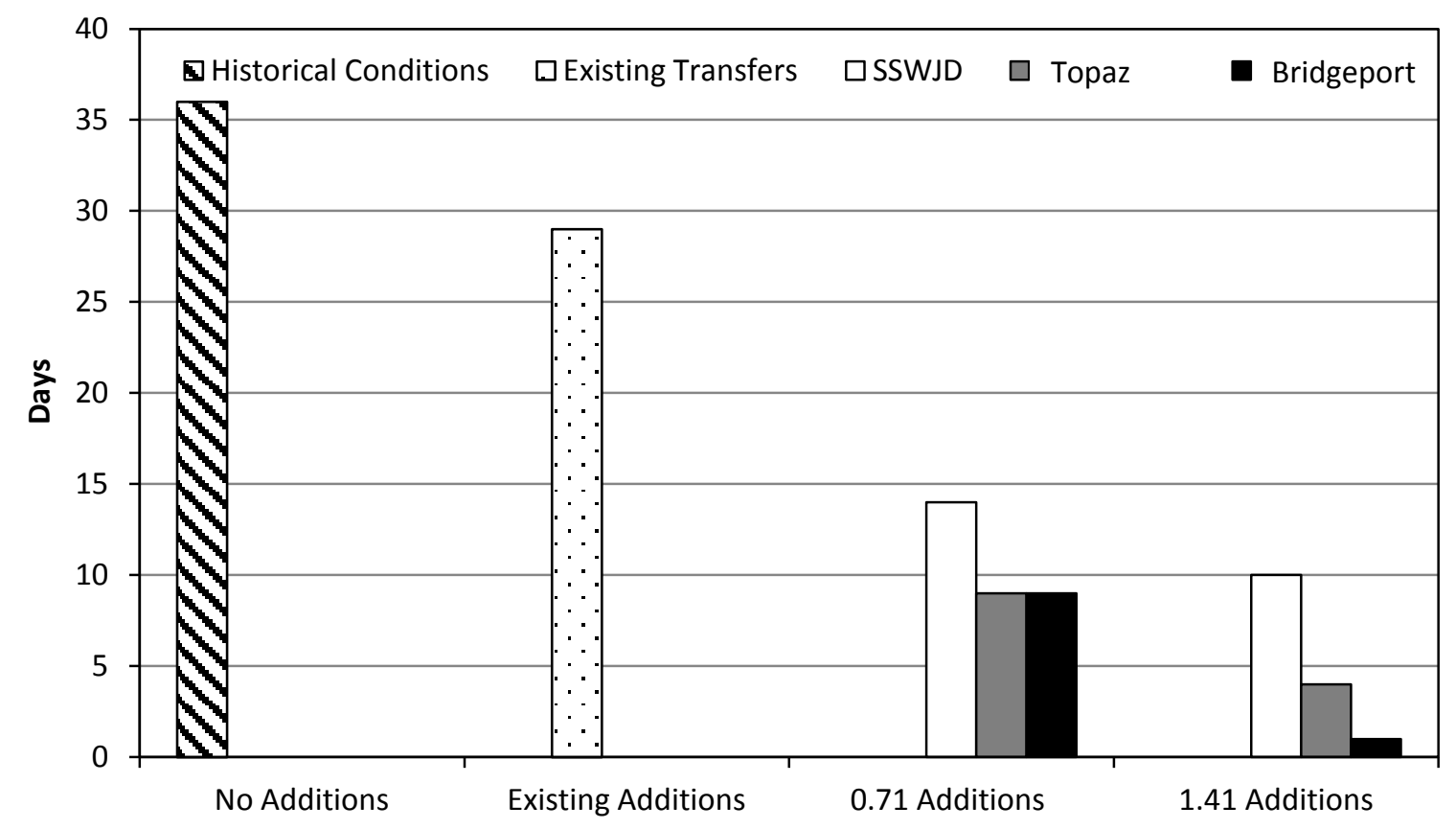

Figure 5-3: Number of days in 2012 that stream temperature exceeded $28^{\circ} \mathrm{C}$ for all reaches in selected model runs. 


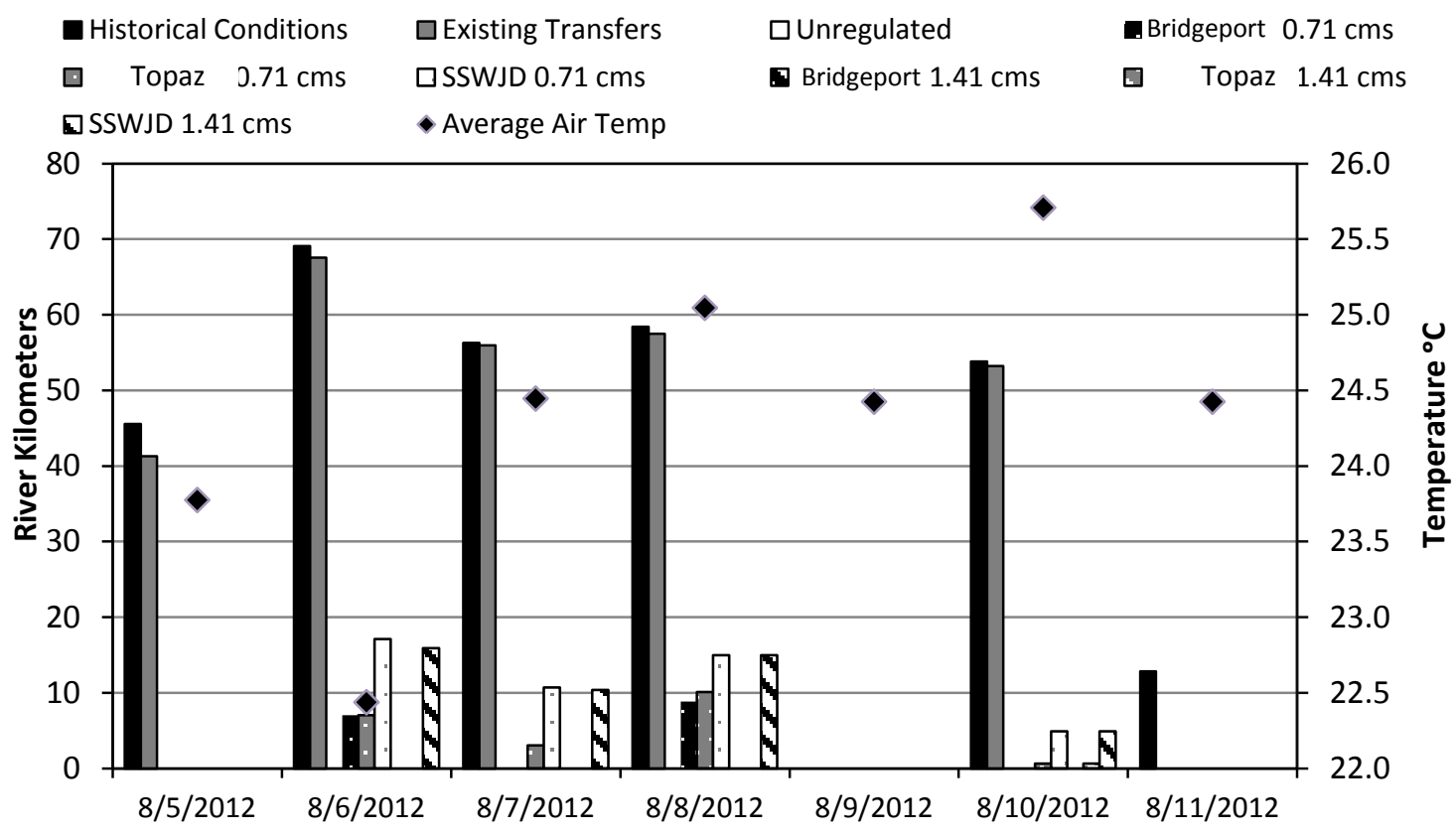

Figure 5-4: River length that maximum daily stream temperatures exceeded $28^{\circ} \mathrm{C}$ for all reaches in selected model runs during the hottest week in 2012. Point data are the average daily air temperatures for comparison.

\subsection{Limitations}

Simulating hourly stream temperatures for approximately 300 river kilometers in two drastically different water years is not without limitations. RMS, like all models, simplifies river systems and water management. Better flow data for diversion canals and return flows would improve modeling. Further, this modeling did not consider the political, legal, or economic feasibility or purchasing water for environmental transfers. This work focuses entirely on stream temperature and instream flow aspects of environmental water transfers to highlight thermal effects of water transfers rather than political or economic challenges.

As mentioned earlier, a limitation of RMS is the inability to accurately simulate stream temperatures below approximately $10{ }^{\circ} \mathrm{C}$ (Hauser pers. comm. 2014). Stream 
temperatures regularly fall below $10^{\circ} \mathrm{C}$ during early spring and fall in the Walker River (Figure 2-2; Figure 2-3). These time periods generally were outside the irrigation season and were excluded from- calibration and results. As with all modeling studies, trend in stream temperatures are more telling for anticipating the effects of environmental water transfers than exact degree changes. An additional complication for future stream temperature management in the Walker River is projected climate change, which is ignored here. Research suggests that reduced precipitation and warmer air temperatures will shift the dominant form of precipitation from snow to rain, causing flashier systems with earlier spring runoff (Palmer et al. 2009; Arismendi et al. 2013), which may further increase stream temperatures (Ficklin et al. 2011; Null et al. 2013). Regardless, this research provides quantitative estimates of stream temperatures with environmental water transfers for a range of hydrologic conditions represented by wet and dry years. 


\section{CHAPTER 6}

\section{CONCLUSIONS}

Thermal refugia currently exist in the East Walker River upstream of river km 160 during irrigation season when other river reaches are thermally limited.

Environmental water transfers can improve stream temperatures by increasing thermal mass in dry years. Increasing streamflow reduces maximum daily stream temperatures although minimum daily temperatures warm and 7 day average stream temperatures generally remain unchanged.

The extremely dry conditions of water year 2012 marked the beginning of a prolonged drought in California and Nevada, and demonstrate that environmental water transfers have a greater effect on stream temperatures in dry years. This research suggests that water year types matter for aquatic habitat and also that managing aquatic habitats in different water years and with different hydrologic conditions may require a range of strategies. Recent research has shown that ecosystems in regulated rivers receive relatively greater shortages than economic water uses (like water supply and hydropower generation) in dry years when instream flows are typically a smaller proportion of unregulated flows (Null and Viers 2013). Environmental water transfers from willing sellers may be a strategy to mitigate for this and provide an opportunity to manage regulated rivers with the warmer and drier conditions anticipated with climate change.

The most promising environmental water transfer opportunities for the Walker Basin increased instream flow at either Topaz or Bridgeport Reservoirs, the upstream model boundaries. The $1.41 \mathrm{cms}$ water transfer alternatives at these locations provided the greatest reduction $\left(>1^{\circ} \mathrm{C}\right)$ of stream temperatures for the longest distance $(25+\mathrm{rkms})$. 
Further, streamflows and temperatures are most improved if purchased water is not stored in Weber Reservoir, but released to Walker Lake. Currently, the furthest downstream 25 $\mathrm{km}$ of the Walker River has the lowest flows and the warmest stream temperatures, with poor habitat inhabited by invasive species such as carp (Cyprinus carpio) and catfish (Ictalurus punctatus). This reach is consistently most affected by very warm stream temperatures, providing the greatest opportunity for environmental water transfers to improve habitat and increase longitudinal connectivity for LCT. Even by transferring or releasing relatively small amounts of water such as $0.71 \mathrm{cms}$, the number of days and river miles with acute thermal limitation are reduced, improving the quality of the habitat for LCT. This also may increase the connectivity of LCT longitudinally throughout the river, allowing them to move throughout the river and escape extreme high temperatures in low flow situations, particularly in more upstream reaches. The very small environmental water transfers of 0.14 and $0.28 \mathrm{cms}$ were not beneficial and should not be considered for decision-making, except where additional purchases are likely so that cumulative flows could be measurably increased by numerous small environmental water purchases.

The No Diversions alternative runs indicated that stream temperatures exceeded chronic and acute thermal limits in some locations and time periods without diversions from the Walker River. This suggests that restoration should not focus exclusively on environmental water transfers to improve conditions in the Walker River. Water transfers increase streamflow and reduce stream temperature to an extent, but restoration will be most effective if paired with other approaches, such as maintaining healthy riparian vegetation communities, improving channel complexity, eradicating invasive 
species, or limiting nutrient-rich tailwater return flows that deplete dissolved oxygen levels in the river.

Perhaps most importantly, the modeled results of this study contribute to our understanding of instream flow research by demonstrating that simply adding water to a river system does not necessarily improve fish habitat. For decades, most instream flow research has focused on the importance of adding water to river systems with the assumption that the water quality in the system will be automatically improved (Gore and Nestler 1988; Stanford et al. 1996; Arthington et al. 2004; Petts 2009). This concept also extended into the environmental water transfer literature, where the main objective was to acquire water for the system without concern for the quality of the water acquired (Isé and Sunding 1998; Landry 1998; Katz 2006; Loomis et al. 2003; Acreman and Dunbar 2004; Jones and Colby 2010).

While the idea of increasing river flows to mimic natural levels is warranted (Poff et al. 1997), considering water quality of environmental purchases enables streamflow contributions to most improve habitat in impaired river systems. Incorporating water quality into instream flow and environmental water transfer science is needed for both researchers and decision makers - especially as competition for freshwater increases in water scarce regions. Further, this study shows that focusing on water quality and quantity greatly improves instream conditions, even if it does not solve all aquatic degradation. In the Walker River, the best alternative is purchasing cool upstream reservoir water transfers of $1.41 \mathrm{cms}$ at Bridgeport Reservoir, providing the longest reach of river with suitable streamflow and temperature conditions. This thesis demonstrates that careful and systematic modeling of water quality and quantity can prioritize 
restoration decision making by selecting the best management strategy for the system, thereby improving our understating of instream flow management as whole.

Finally, process-based hydrodynamic and stream temperature modeling is helpful to predict stream temperature response to environmental water transfers. The methods and research carried out in this thesis provides managers with quantitative estimates of the number of river kilometers and number of days that stream temperatures exceed chronic and acute stream temperature limits for LCT. These estimates provide crucial insight into prioritizing environmental water purchases for restoration, thereby bridging the aspects of instream flow science and thermal management in regulated river systems. 


\section{LITERATURE CITED}

Acreman M, and Dunbar MJ 2004. Defining environmental river flow requirements-a review. Hydrology and Earth System Sciences 8(5) 861-876.

Arismendi I, Safeeq M. Johnson SL, Dunham JB, and Haggerty R 2013. Increasing synchrony of high temperature and low flow in western North American streams: double trouble for coldwater biota? Hydrobiologia 712: 61-70.

Arthington AH, Tharme RE, Brizga SO, Pusey BJ, and Kennard MJ 2004.

Environmental flow assessment with emphasis on holistic methodologies.

Proceedings of the Second International Symposium on the Management of Large Rivers for Fisheries 2:37-66.

Bartholow JM 1991. A modeling assessment of the thermal regime for an urban sport fishery. Environmental Management 15(6): 833-845.

Brown GW 1970. Predicting the effect of clear cutting on stream temperature. Journal of Soil and Water Conservation 25(1) 11-13.

California Department of Water Resources-California Data Exchange Center (CDEC). 2013 Available online http://cdec.water.ca.gov/. Accessed on 6/2013

Cassie D 2006. The thermal regime of rivers: a review. Freshwater Biology 51: 13891406

Chapra SC 1997. Surface water-quality modeling. Long Grove, Illinois: Waveland Press, Inc.

Chinnayakanahalli KJ, Hawkins CP, Tarboton DG, and Hill RA 2011. Natural flow regime, temperature and the composition and richness of invertebrate assemblages in stream of the western United States. Freshwater Biology 56: 1248-1265. 
Coffin PD, and Cowan WF 1995. Lahontan cutthroat trout (O. clarki henshawi) recovery plan. U.S. Fish and Wildlife Service, Region I, Portland, Oregon.

Conner WP, Burge HL, and Bennet DH 1998. Detection of PIT-tagged subyearling Chinook salmon at a Snake River Dam; implementations for summer flow augmentation. North American Journal of Fisheries Management 18: 530-536.

Conner WP, Burge HL, Yearsley JR, and Bjornn TC 2003. Influence of flow and temperature on survival of wild subyearling fall Chinook salmon in the Snake River. North American Journal of Fisheries Management 23: 362-375.

Danehy RJ, Colson CG, Parrett KB, and Duke SD 2004. Patterns and sources of thermal heterogeneity in small mount streams within a forested setting. Forest Ecology and Management 208(2005): 287-322.

Desert Research Institute Meteorological Station (DRI) 2014. http://mesowest.utah.edu/cgi-bin/droman/station_total.cgi?stn=NSMV\&unit=0

Dickerson BR and Vinyard GL 1999. Effects of high chronic temperatures and diel temperature cycles on the survival and growth of Lahontan cutthroat trout. Transactions of the American Fisheries Society 128: 516-521.

Dunham J 1999. Stream temperature criteria for Oregon's Lahontan cutthroat trout Oncorhynchus clarki henshawi. Report to Oregon Department of Environmental Quality.

Dunham J, Schroeter R, and Rieman, B 2003. Influence of maximum water temperature on occurrence of Lahontan cutthroat trout with streams. North American Journal of Fisheries Management. 23: 1042-1049. 
Ficklin DL, Stewart IT, and Maurer EP 2011. Projections of $21^{\text {st }}$ century Sierra Nevada local hydrologic flow components using an ensemble of general circulation models. Journal of the American Water Resources Association (JAWRA) 48(6): 1104-1125.

Gore JA and Nestler JM 1988. Instream flow studies in perspective. Regulated Rivers 2(2): 93-101.

Harvey BC, Nakamoto RJ, and White JL 200. Reduced streamflow lowers dry season growth of rainbow trout in a small stream. Transactions of the American Fisheries Society 135: 998-1005.

Hawkins CP, Hogue JM, Decker LM and Feminella JW 1997. Channel morphology, water temperature, and assemblage structure of stream insects. The North America Benthological Society 16(4): 728-749.

Hauser GE, and Schohl GA 2002. River Modeling System v4—User Guide and Technical Reference. Report No. WR28-1-590-164. TVA River System Operations and Environment, Norris, Tennessee.

Isé S, and Sunding DL 1998. Reallocating water from agriculture to the environment under avoluntary purchase program. Review of Agriculture Economics 20: 214226.

Jones J 1992. Walker River Atlas. State of California, The Resources Agency, Department of Water Resources. Sacramento, California. $112 \mathrm{p}$.

Jones L, and Colby B 2010. Weather, climate, and environmental water transactions. Weather, Climate, and Society 2: 210-223. 
Katz D 2006. Going with the Flow: Preserving and restoring instream water allocations. In The World's Water: 2006-2007 (pp. 29-49). Washington, D.C: Island Press.

Landry C 1998. Market transfers of water for environmental protection in the western United States. Water Policy 1: 457-469.

Loomis JB, Quattlebaum K, Brown TC, and Alexander SJ 2003. Expanding institutional arrangements for acquiring water for environmental purposes: transactions evidence for the western United States. Water Resources Development 19-1: 21-28.

Meyer KA, Lamansky JA, and Schill DJ 2010. Biotic and abiotic factors related to redband trout occurrence and abundance in desert and montane streams. Western North American Naturalist 70(1): 77-91.

Meier W, Bonjour C, Wüest A, and Reichert P 2003. Modeling the effect of water diversion on the temperature of mountain streams. Journal of Environmental Engineering. 129: 755-764.

Moriasi DN, Arnold JG, Van Liew MW, Bingner RL, Harmel RD, and Veith TL 2007. Model evaluation guidelines for systematic quantification of accuracy in watershed simulations. American Society of Agricultural and Biological Engineers. 50(3): 885-900.

Neville H, Dunham J, and Peacock M 2006. Landscape attributes and life history variability shape genetic structure of trout populations in a stream network. Landscape Ecology, 21(6), 901-916. 
The Nature Conservancy (TNC). 2013. Conservation Action Plan for Walker Lake. The Nature Conservancy, Reno, Nevada. 51 p.

Null SE, Deas ML, and Lund JR 2010. Flow and water temperature simulation for habitat restoration in the Shasta River, California. River Research and Applications 26: $663-681$.

Null SE and Viers JH 2013. In bad waters: Water year classification in nonstationary climates. Water Resources Research 49(2): 1137-1148.

Null SE, Ligare ST, and Viers JH 2013. A method to consider whether dams mitigate climate change effects on stream temperatures. Journal of American Water Resources Association 40(6): 1456-1472.

Olden JD and Naiman RJ 2010. Incorporating thermal regimes into environmental flows assessments: modifying dam operations to restore freshwater ecosystem integrity. Freshwater Biology 55: 86-107.

Pahl PE 2000. Walker River Basin irrigation diversions. Prepared for Nevada Water Basin Information and Chronology Series. State of Nevada Department of Water Resources. Carson City, NV. 214 p.

Palmer MA, Letternmaier DP, Poff NL, Postel SL, Richter B, and Warner R 2009. Climate change and river ecosystems: protection and adaptation options. EnvironmentalManagement 44:1053-1068.

Petts GE 2009. Instream flow science for sustainable river management. Journel of the American Resources Association 45(5): 1071-1086.

Poff NL, Allen JD, Bain MB, Karr JR, Prestegaard KL, Richter BD, Sparks RE, and Stromberg JC 1997. The natural flow regime. BioScience 47(11): 769:784. 
Poole GC and Berman CH 2001. An ecological perspective on in-stream temperature: natural heat dynamics and mechanisms of human-caused thermal degradation. Environmental Management 27(6): 787-802.

Rutherford JC, Blackett S, Blackett C, Saito L, and Davies-Colley RJ 1997. Predicting the effects of shade on water temperature in small streams. New Zealand Journal of Marine and Freshwater Research 31: 707-721.

Sedinger JS, Blomberg EJ, VanDellen AW, and Byers S 2012. Environmental and population strain effects on survival of Lahontan cutthroat trout in Walker Lake, Nevada: a Bayesian approach. North American Journal of Fisheries Management 32: $515-522$.

Sharpe SE, Cablk ME, and Thomas JM 2008. The Walker Basin, Nevada and California: physical environment, hydrology, and biology. Report No. 41231. Reno, Nevada. Desert Research Institute.

Sinokrot BA and Gulliver JS 2000. Instream flow impact on river water temperatures. Journal of Hydraulic Research 38(5): 339-349.

Stanford JA, Ward JV, Liss WJ, Frissell CA, and Williams RN 1996. A general protocol for restoration of regulated rivers. Regulated Rivers 12: 391-413.

USFWS (U.S. Fish and Wildlife Service). 1975. Reclassification of Lahontan cutthroat trout to threatened. Federal Register 40:29864.

USGS (United States Geologic Survey) 2014 http://waterdata.usgs.gov/nv/nwis/current/?type=dailydischarge\&group_key=huc _cd\&search_site_no_station_nm=Walker\&site_no_name_select $=$ station_nm. 
Walker River Basin Recovery Implementation Team (WRIT) 2003. Short-term action plan for Lahontan cutthroat trout (Oncorhynchus clarki henshawi) in the Walker River Basin. U.S. Fish and Wildlife Service. Reno, Nevada. 117 p.

Yardas D 2007. Issues and opportunities for acquiring water from willing sellers to increase Walker Lake inflows. Prepared for Natural Resources Conservation Service, US Department of Agriculture. Reno, NV. 353 p. 
APPENDICES 
APPENDIX A:

EQUATIONS 
1.

$$
N S E=1-\left[\frac{\sum_{i=1}^{n}\left(Y_{i}^{o b s}-Y_{i}^{\text {sim }}\right)^{2}}{\sum_{i=1}^{n}\left(Y_{i}^{\text {obs }}-Y_{i}^{\text {mean }}\right)^{2}}\right]
$$

2.

$$
P B I A S=\left[\frac{\sum_{i=1}^{n}\left(Y_{i}^{o b s}-Y_{i}^{s i m}\right) *(100)}{\sum_{i=1}^{n}\left(Y_{i}^{o b s}\right)}\right]
$$

3.

$$
R S R=\frac{R M S E}{S T D E V_{o b s}}=\frac{\left[\sqrt{\sum_{i=1}^{n}\left(Y_{i}^{o b s}-Y_{i}^{s i m}\right)^{2}}\right]}{\left[\sqrt{\sum_{i=1}^{n}\left(Y_{i}^{o b s}-Y_{i}^{s i m}\right)^{2}}\right]}
$$

4.

$$
R M S E=\sqrt{\frac{\sum_{i=1}^{n}\left(Y^{o b s}-Y^{s i m}\right)^{2}}{n}}
$$


APPENDIX B:

CALIBRATION, SENSITIVITY TESTING, AND MODELED RUN PLOTS 
All plots are from river kilometer 2.69 on the Mainstem Walker River near the Mouth of Walker Lake. Plots are shown as stream temperature time series for all available times during irrigation season: 8/1/2011-10/31/2011 and 4/1/2012-10/31/2012.

\section{$\underline{2011 \text { Plots }}$}

Calibration plot: measured versus modeled stream temperature.

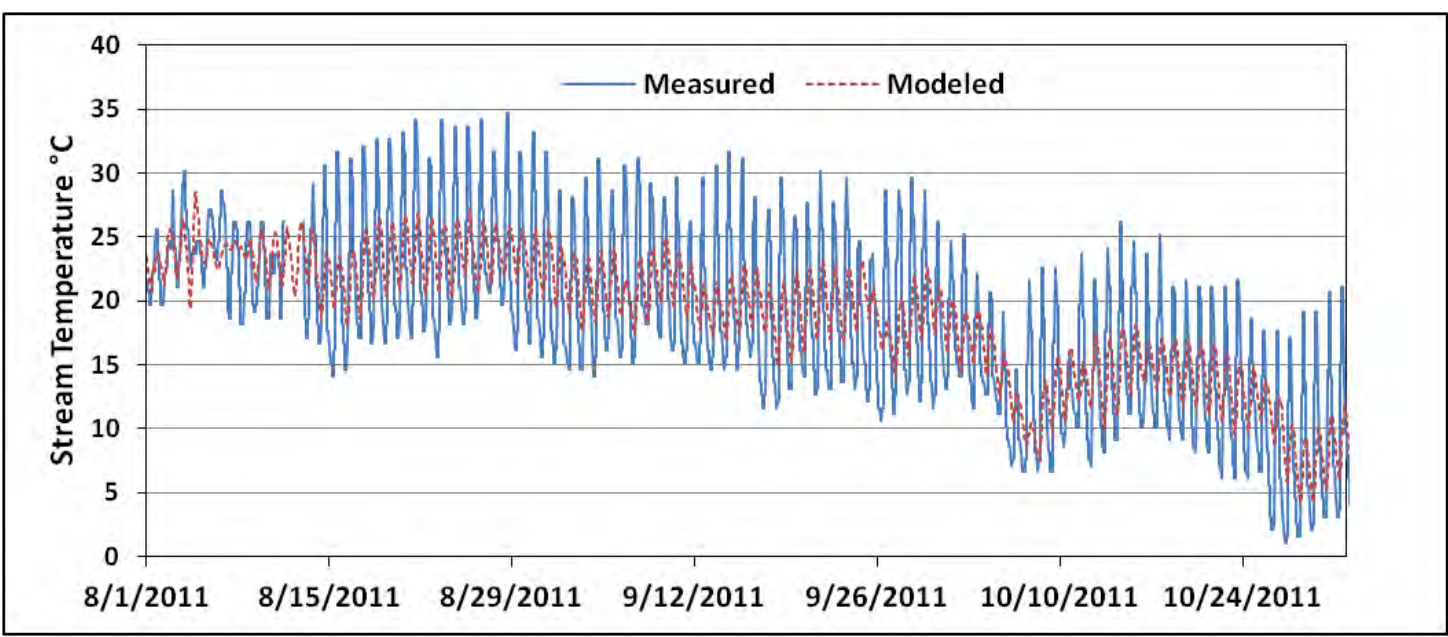

Figure B-1: Measured versus modeled stream temperatures at RKM 2.69 near the mouth of Walker Lake.

Historical Conditions scenario versus existing transfers at Bridgeport Reservoir, BNGHH, SSWJD, GAGE, and COLONY diversion, simulated as one run.

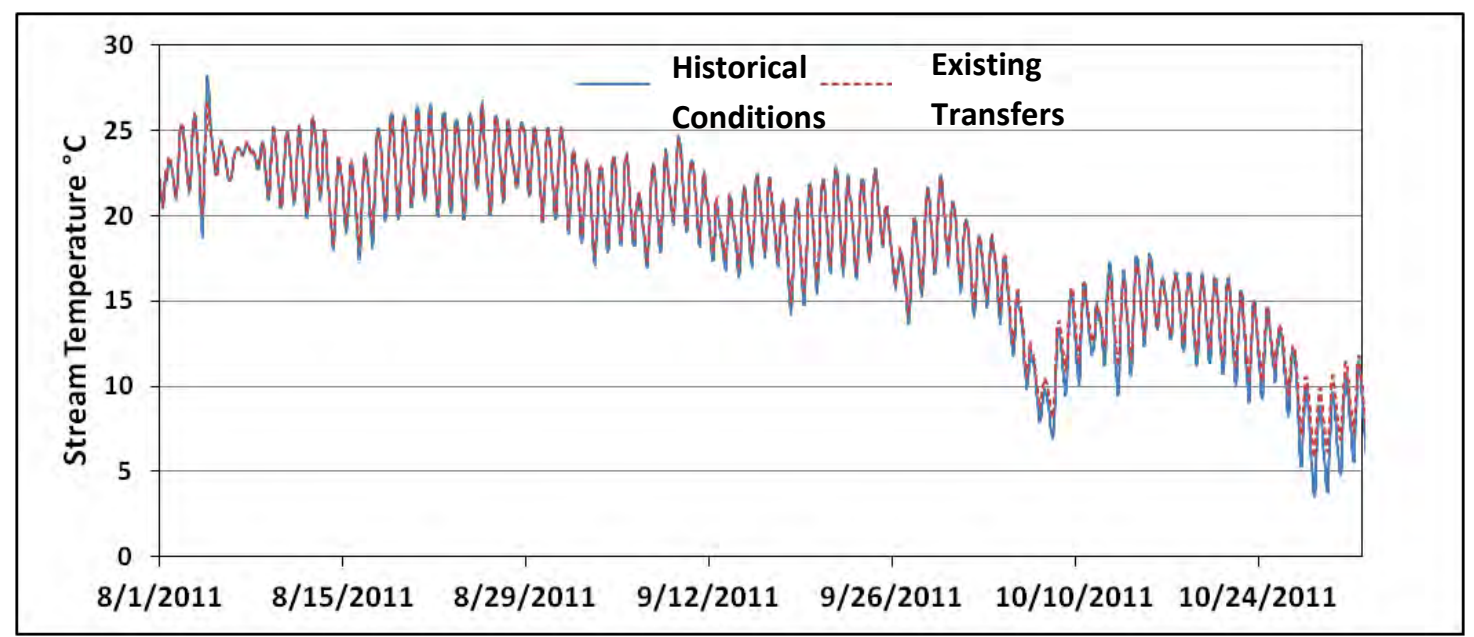

Figure B-2: Historical conditions versus existing transfers stream temperatures at RKM 2.69 near the mouth of Walker Lake. 
Water Transfer Scenario Runs: these plots show the different water right acquisitions of $0.14,0.28,0.71$, and $1.41 \mathrm{cms}$ added at each diversion or reservoir in addition to their existing transfers versus the single existing transfers scenario.

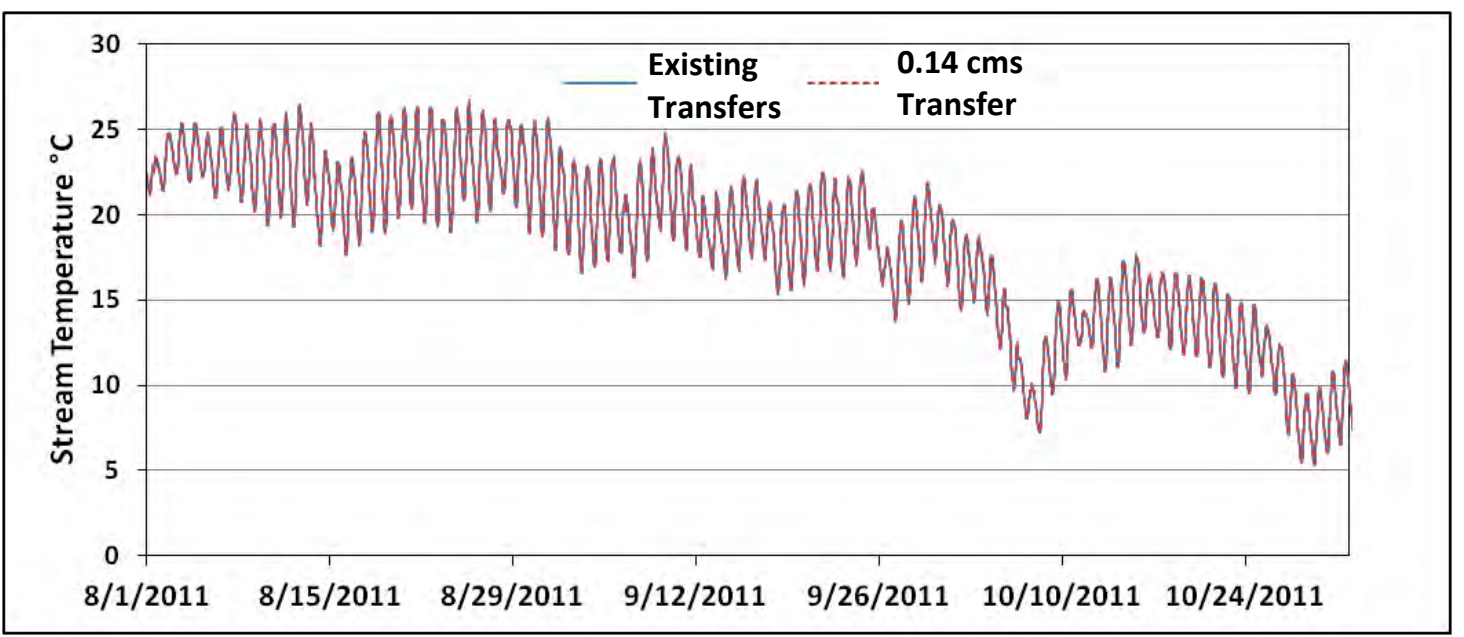

Figure B-3: Existing transfers versus $0.14 \mathrm{cms}$ transfers from Bridgeport Reservoir stream temperatures at RKM 2.69 near the mouth of Walker Lake.

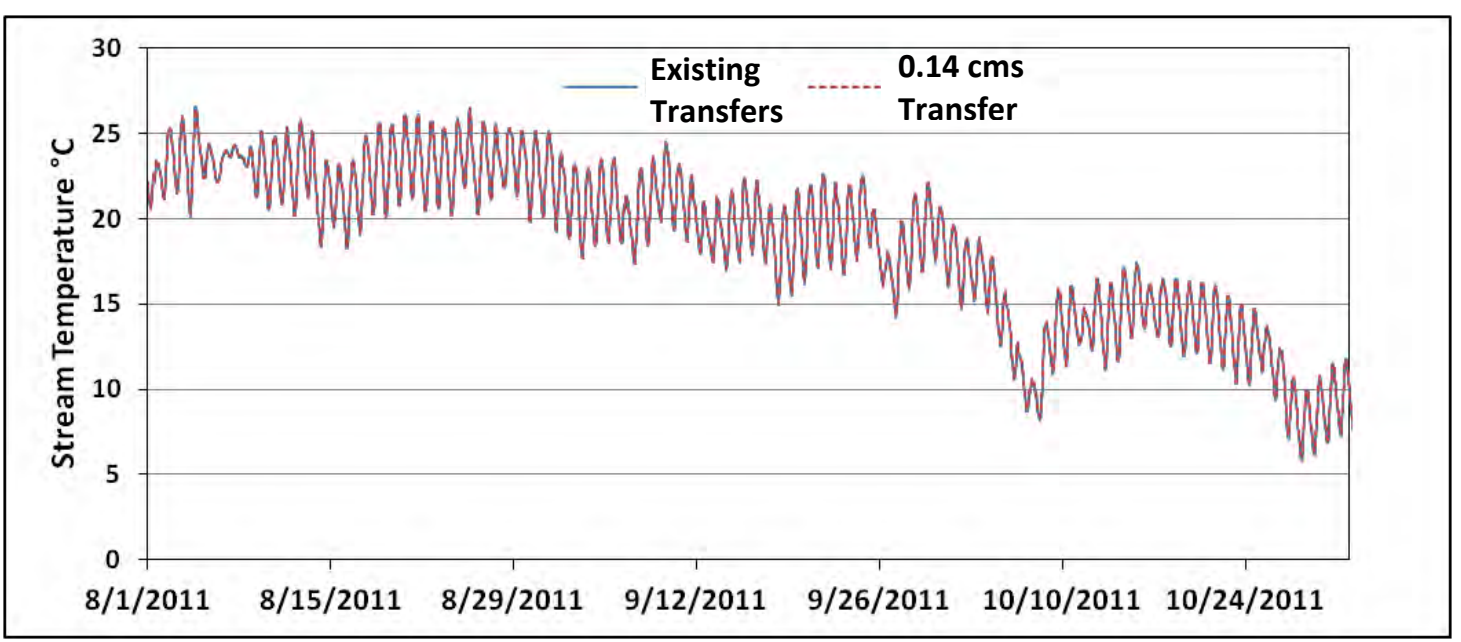

Figure B-4: Existing transfers versus $0.14 \mathrm{cms}$ transfers from BNGHH diversion stream temperatures at RKM 2.69 near the mouth of Walker Lake. 


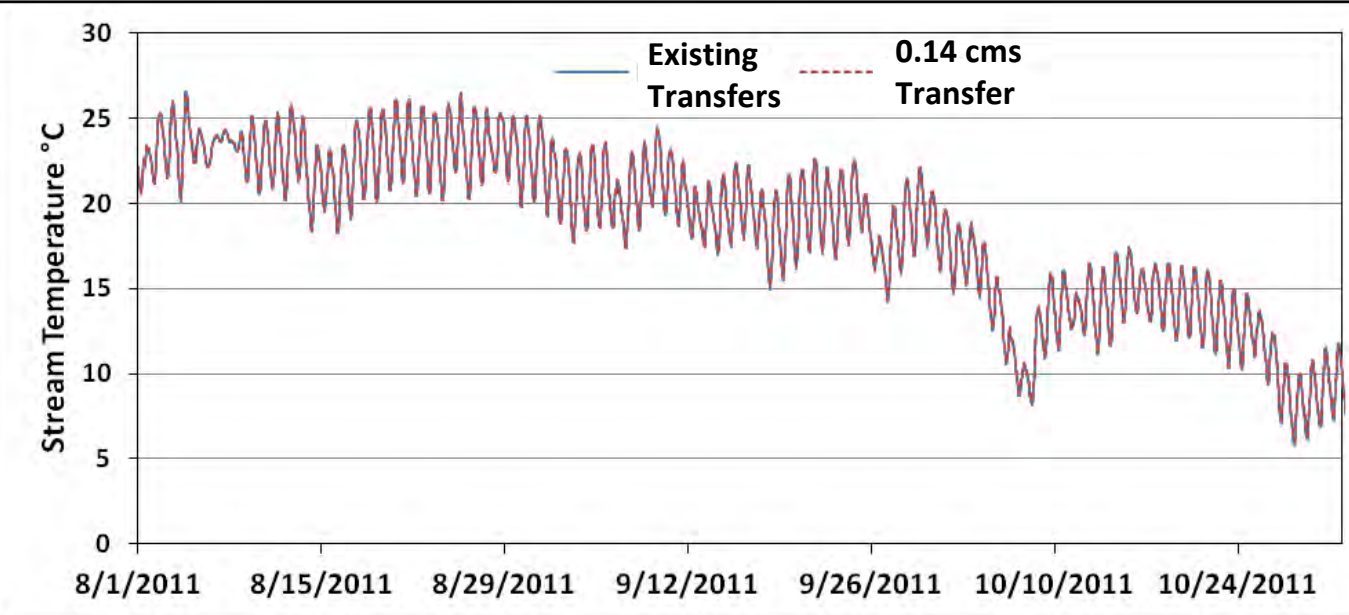

Figure B-5: Existing transfers versus $0.14 \mathrm{cms}$ transfers from FOX diversion stream temperatures at RKM 2.69 near the mouth of Walker Lake.

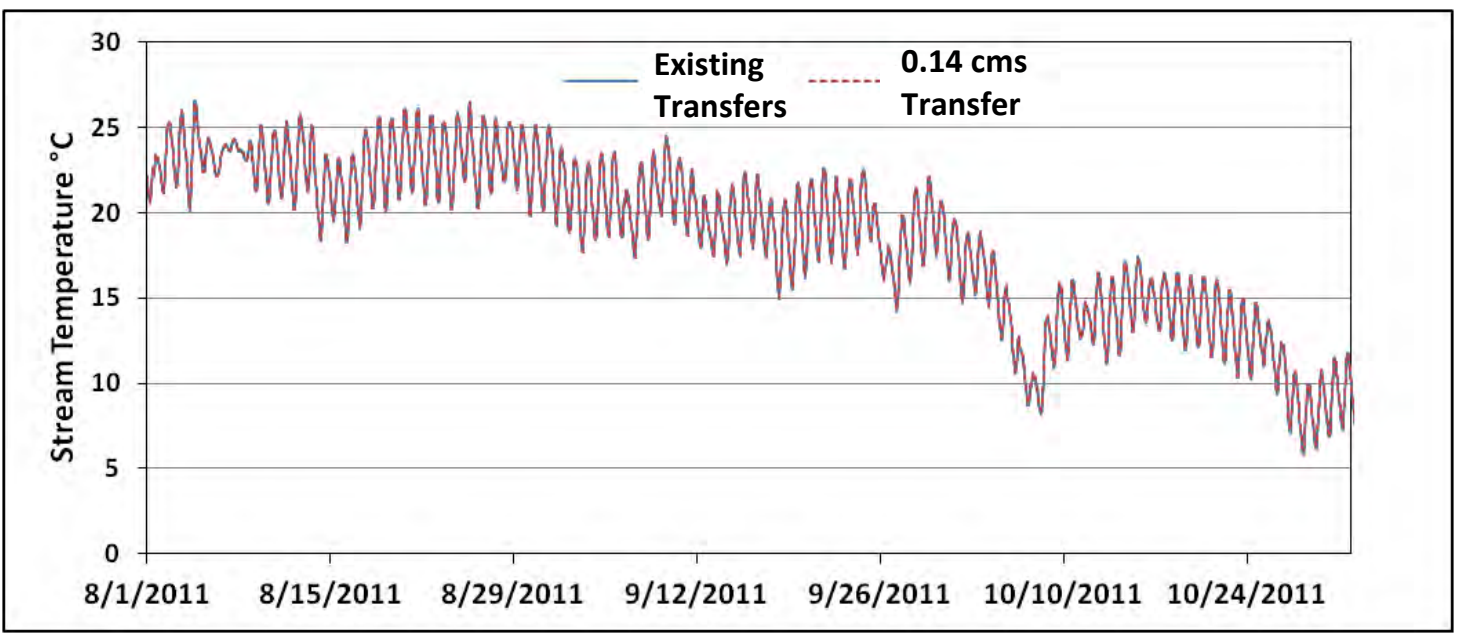

Figure B-6: Existing transfers versus $0.14 \mathrm{cms}$ transfers from MCCAMP diversion stream temperatures at RKM 2.69 near the mouth of Walker Lake. 


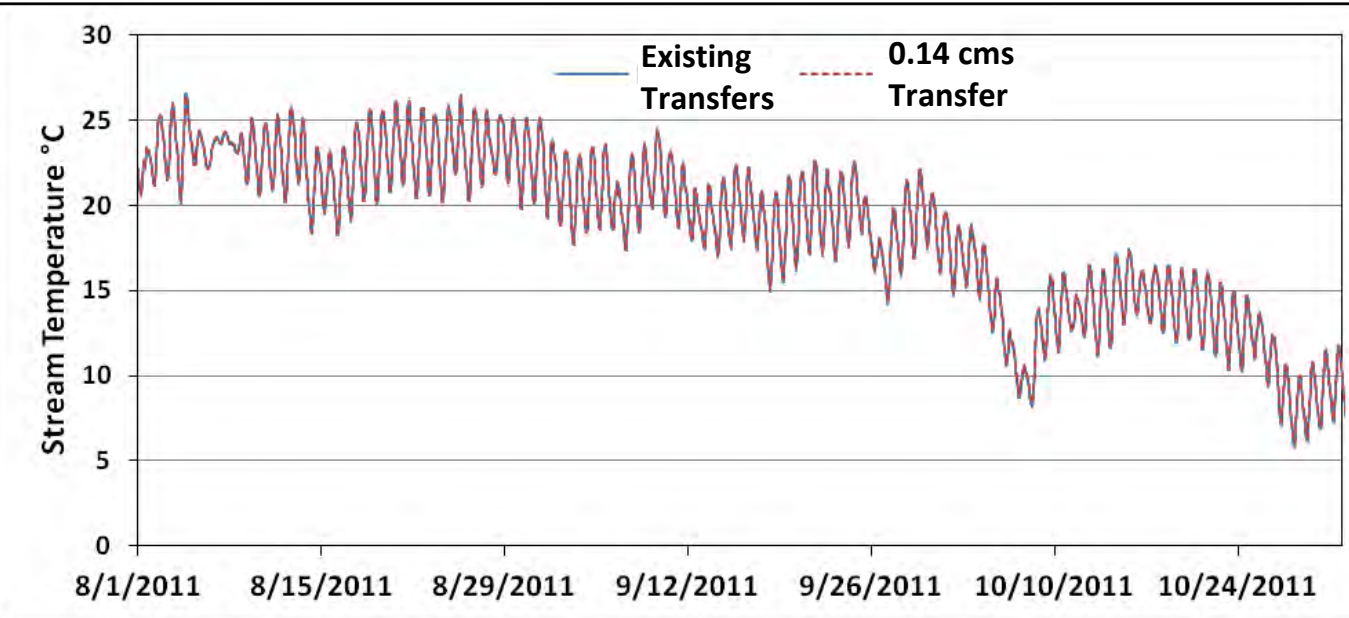

Figure B-7: Existing transfers versus $0.14 \mathrm{cms}$ transfers from SSWJD diversion stream temperatures at RKM 2.69 near the mouth of Walker Lake.

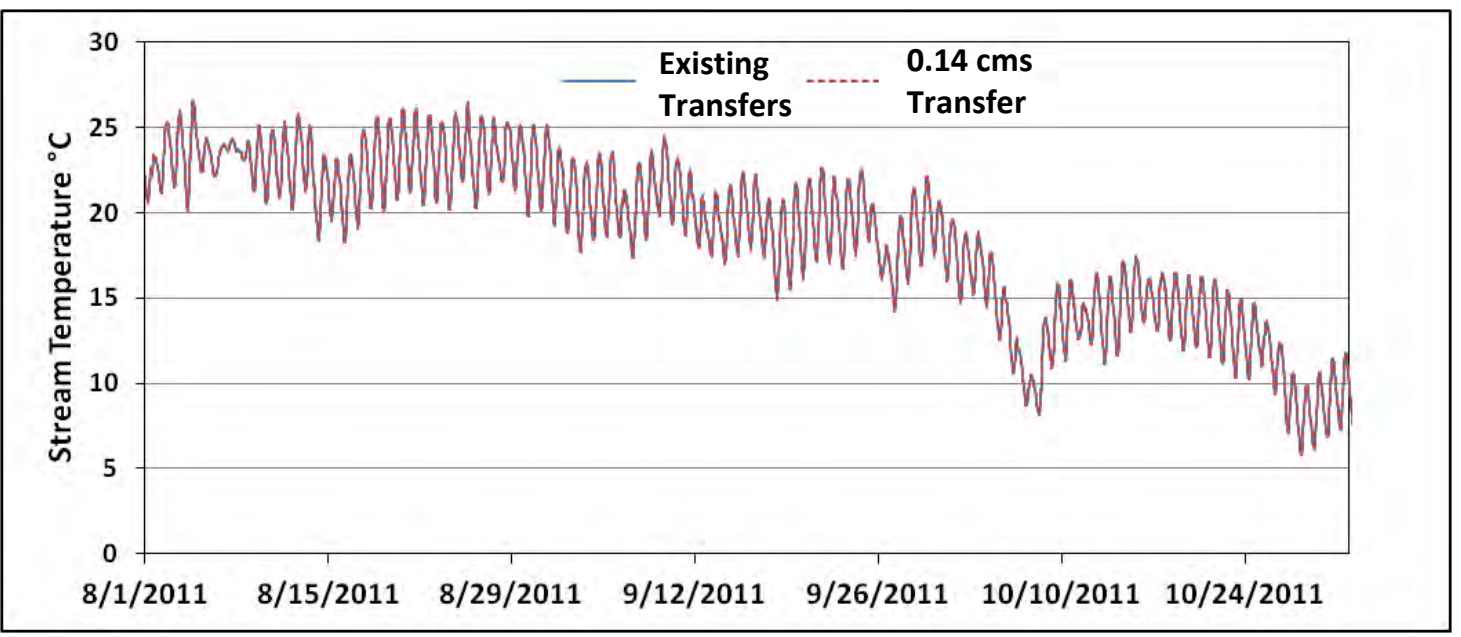

Figure B-8: Existing transfers versus $0.14 \mathrm{cms}$ transfers from CANAL diversion stream temperatures at RKM 2.69 near the mouth of Walker Lake. 


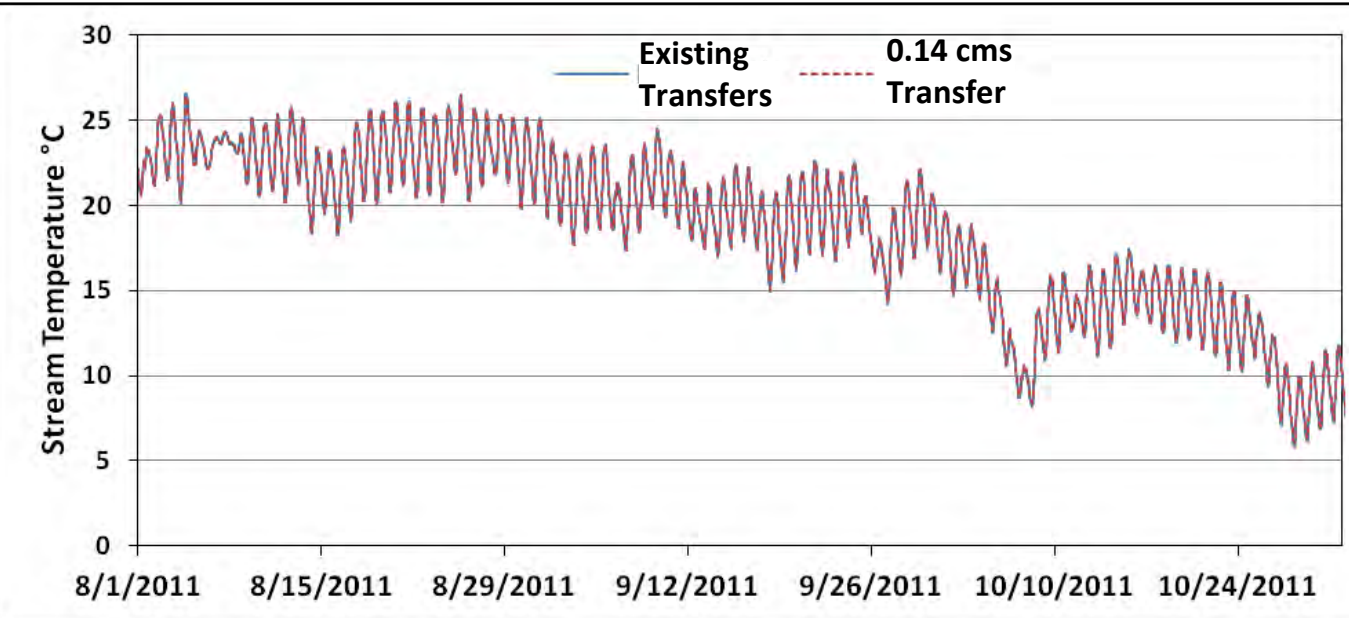

Figure B-9: Existing transfers versus $0.14 \mathrm{cms}$ transfers from SARONI diversion stream temperatures at RKM 2.69 near the mouth of Walker Lake.

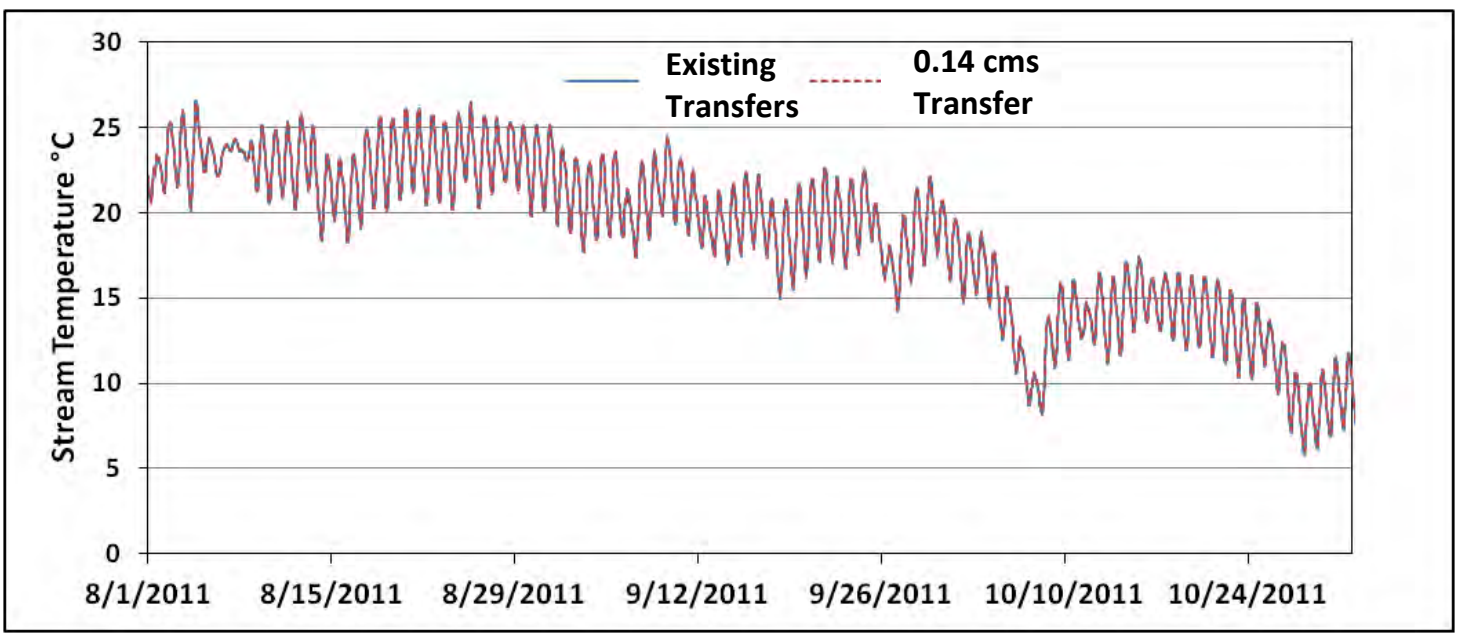

Figure B-10: Existing transfers versus $0.14 \mathrm{cms}$ transfers from GAGE diversion stream temperatures at RKM 2.69 near the mouth of Walker Lake. 


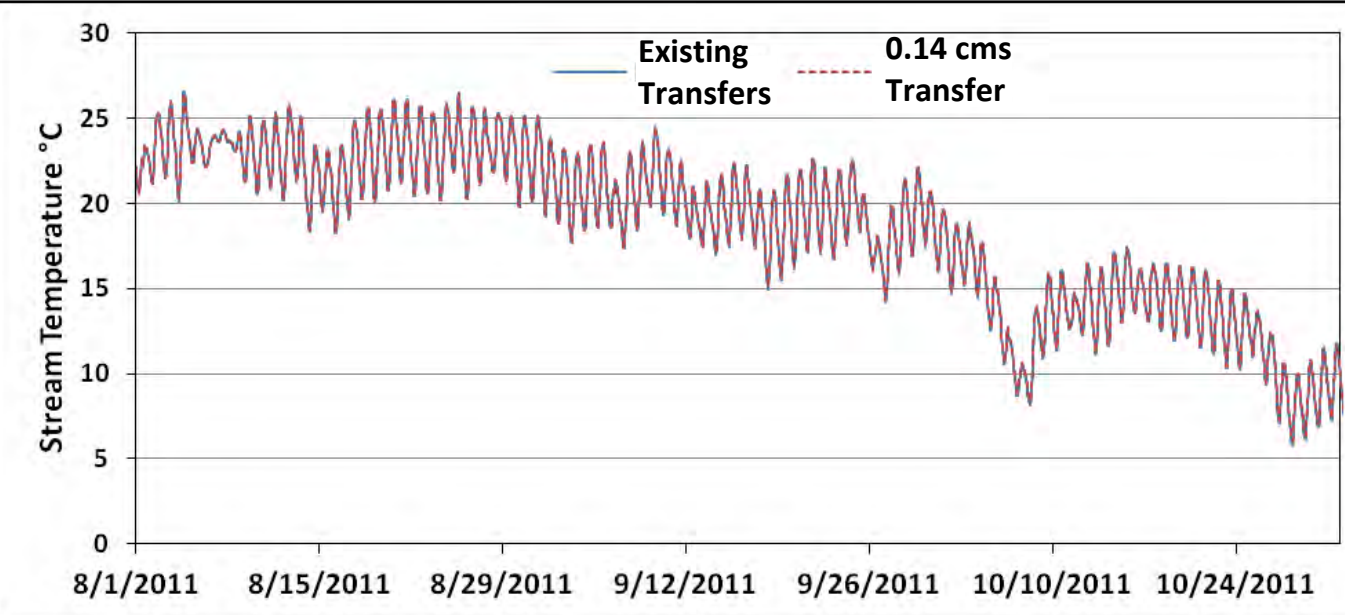

Figure B-11: Existing transfers versus $0.14 \mathrm{cms}$ transfers from COLONY diversion stream temperatures at RKM 2.69 near the mouth of Walker Lake.

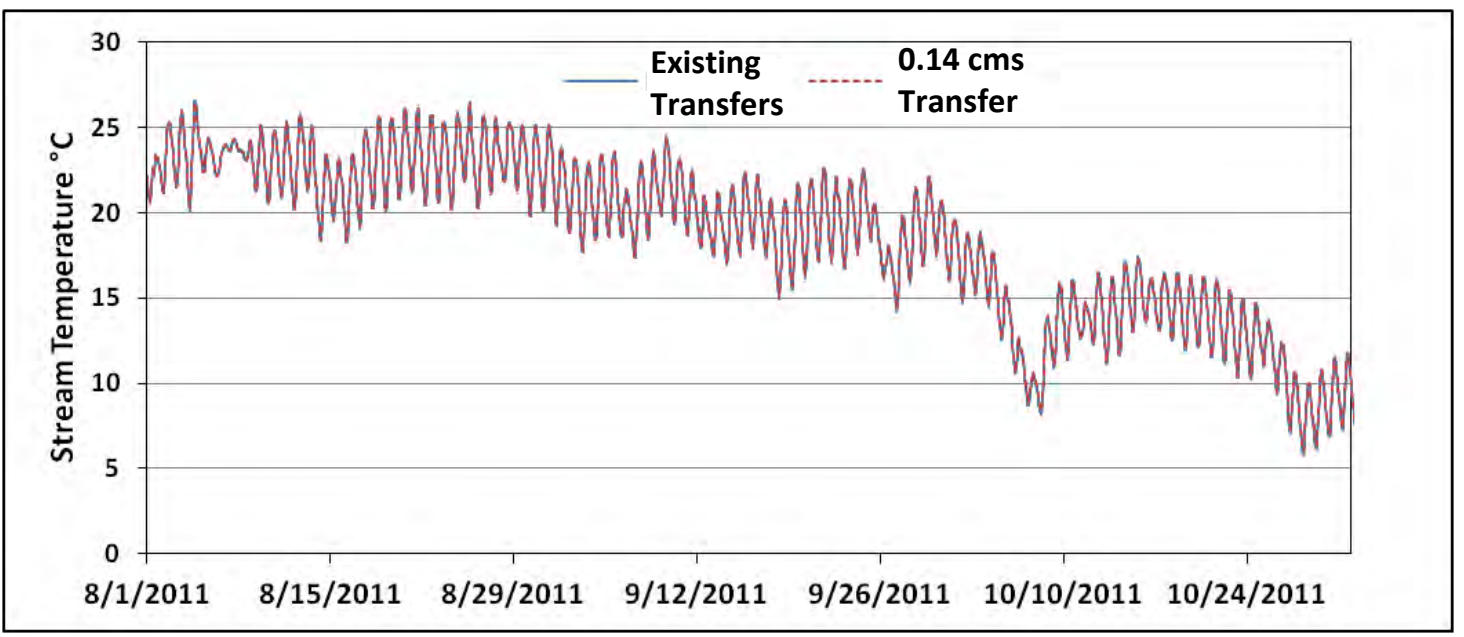

Figure B-12: Existing transfers versus $0.14 \mathrm{cms}$ transfers from TUNNEL diversion stream temperatures at RKM 2.69 near the mouth of Walker Lake. 


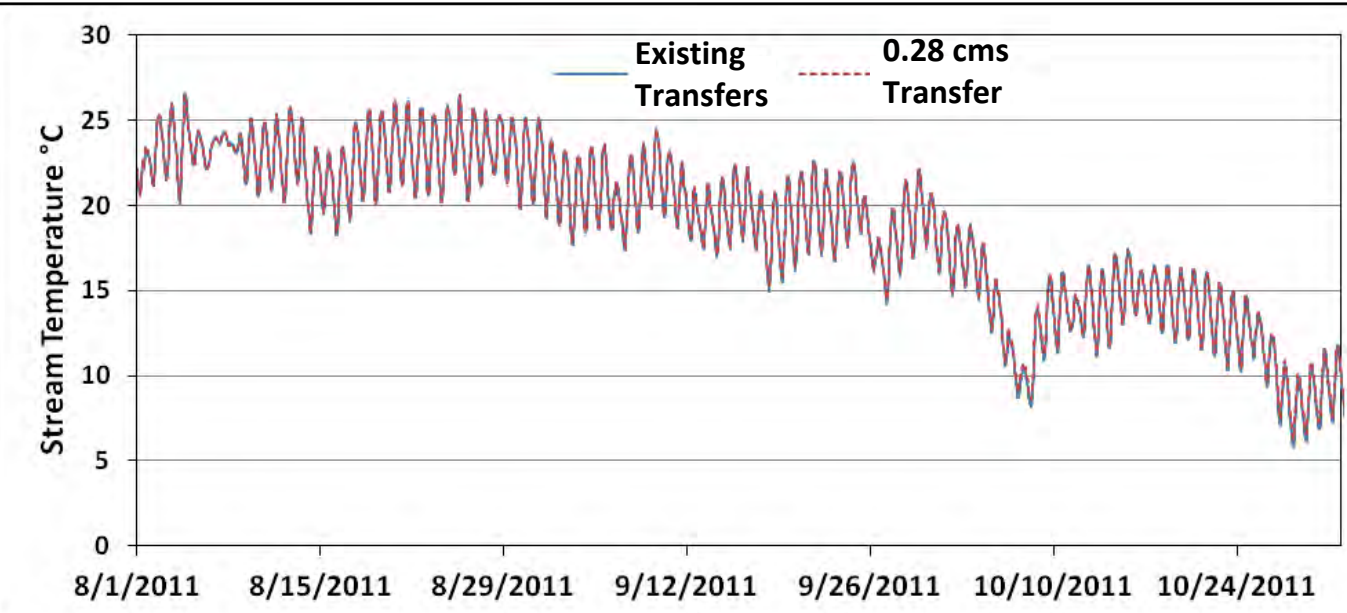

Figure B-13: Existing transfers versus $0.28 \mathrm{cms}$ transfers from Bridgeport Reservoir stream temperatures at RKM 2.69 near the mouth of Walker Lake.

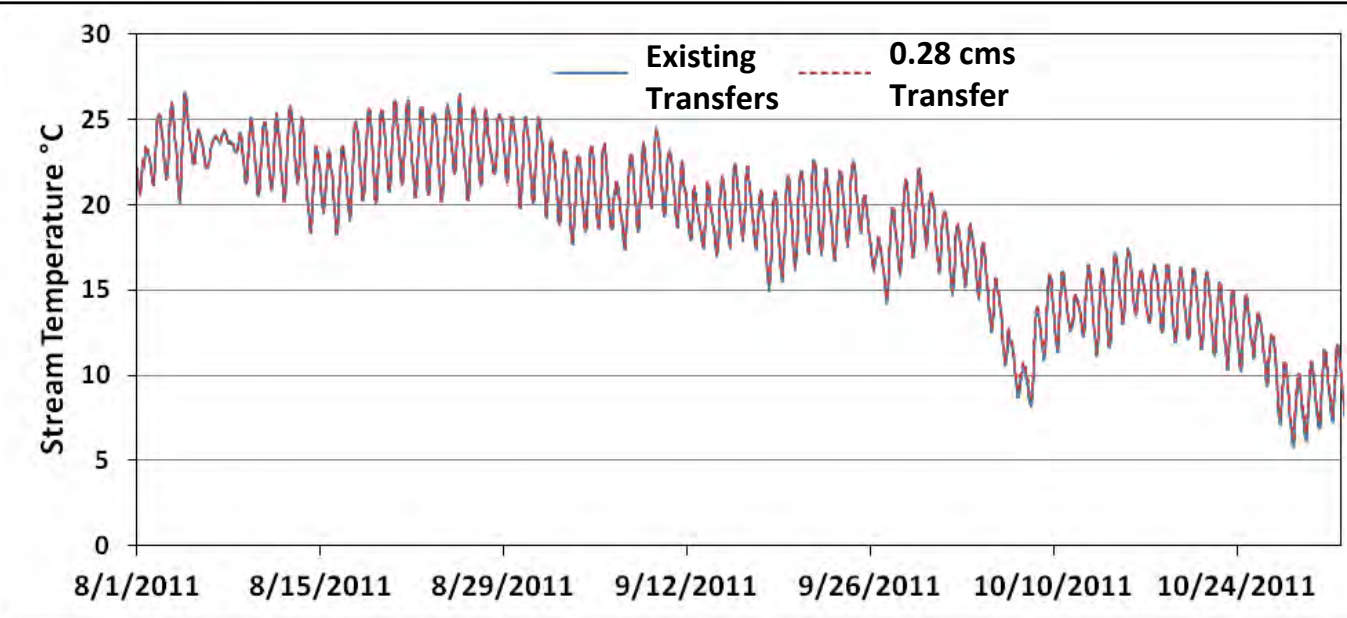

Figure B-14: Existing transfers versus $0.28 \mathrm{cms}$ transfers from BNGHH diversion stream temperatures at RKM 2.69 near the mouth of Walker Lake. 


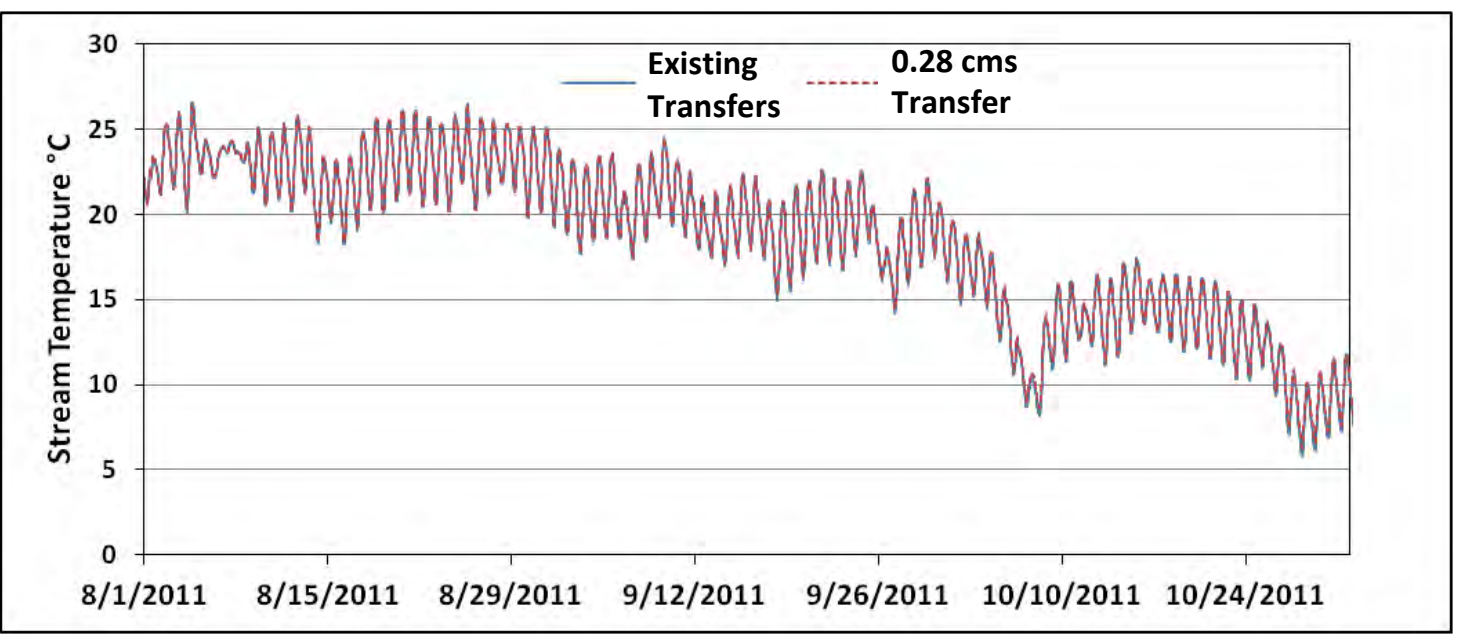

Figure B-15: Existing transfers versus $0.28 \mathrm{cms}$ transfers from FOX diversion stream temperatures at RKM 2.69 near the mouth of Walker Lake

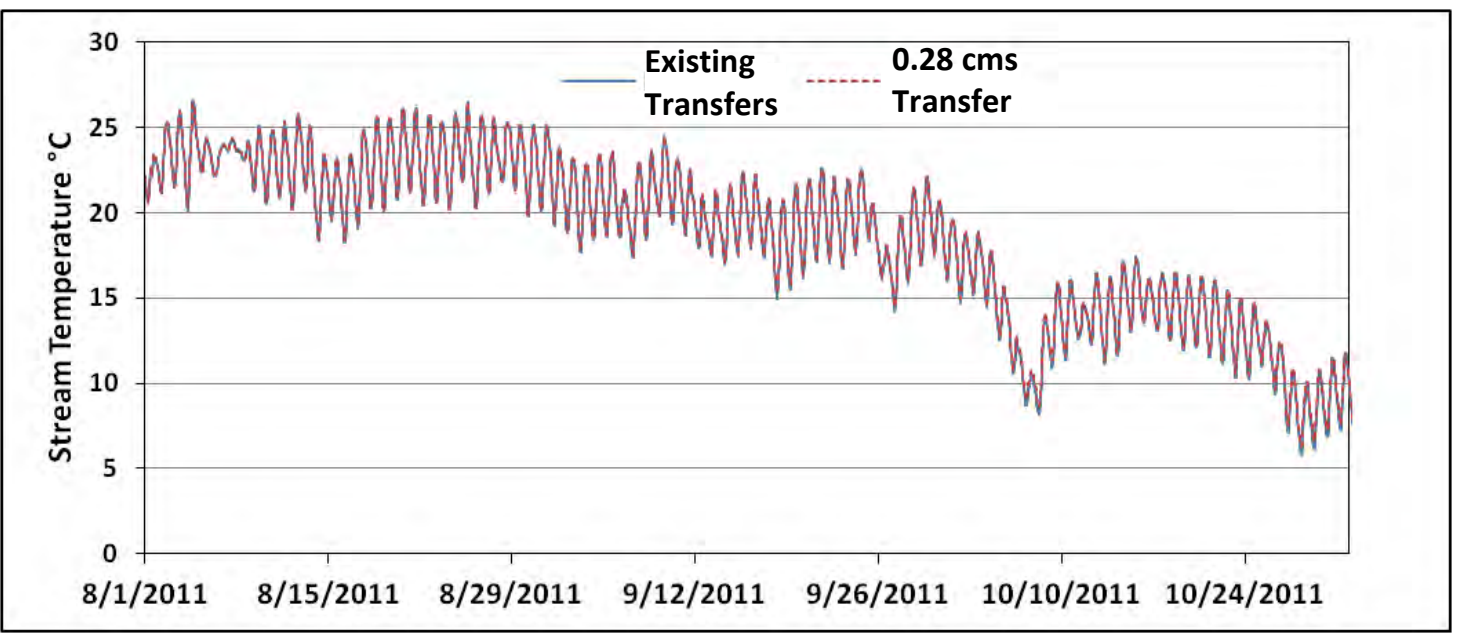

Figure B-16: Existing transfers versus $0.28 \mathrm{cms}$ transfers from MCCAMP diversion stream temperatures at RKM 2.69 near the mouth of Walker Lake. 


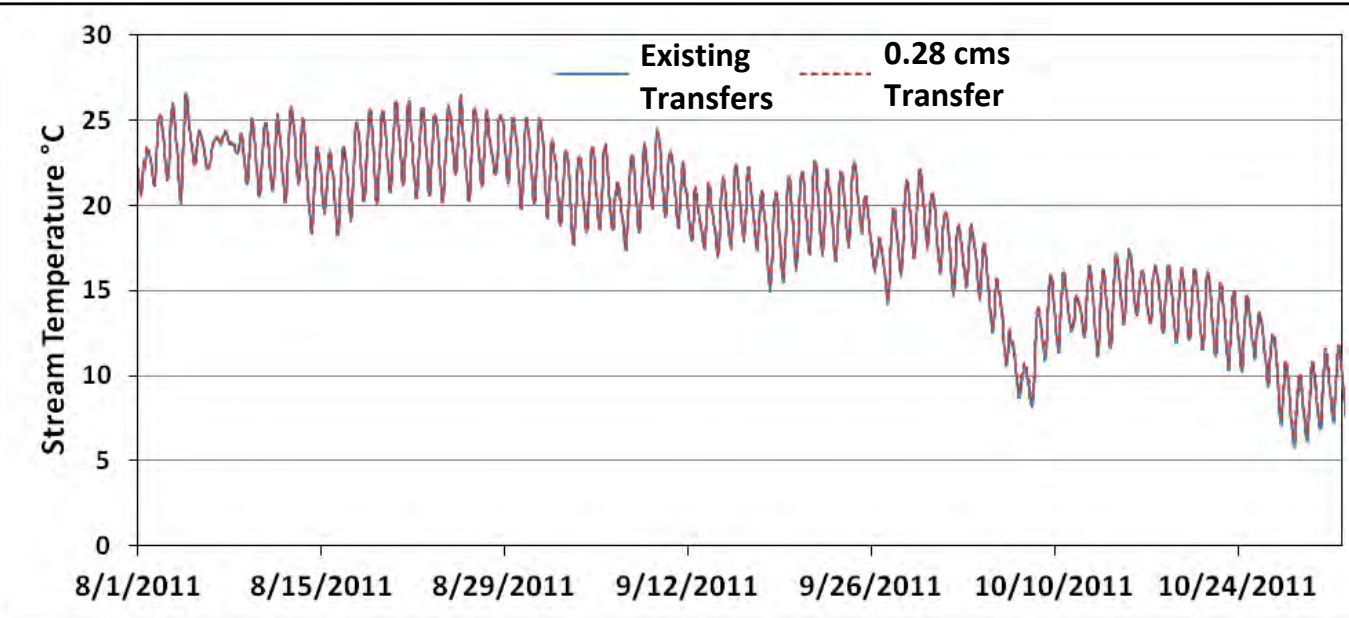

Figure B-17: Existing transfers versus $0.28 \mathrm{cms}$ transfers from SSWJD diversion stream temperatures at RKM 2.69 near the mouth of Walker Lake.

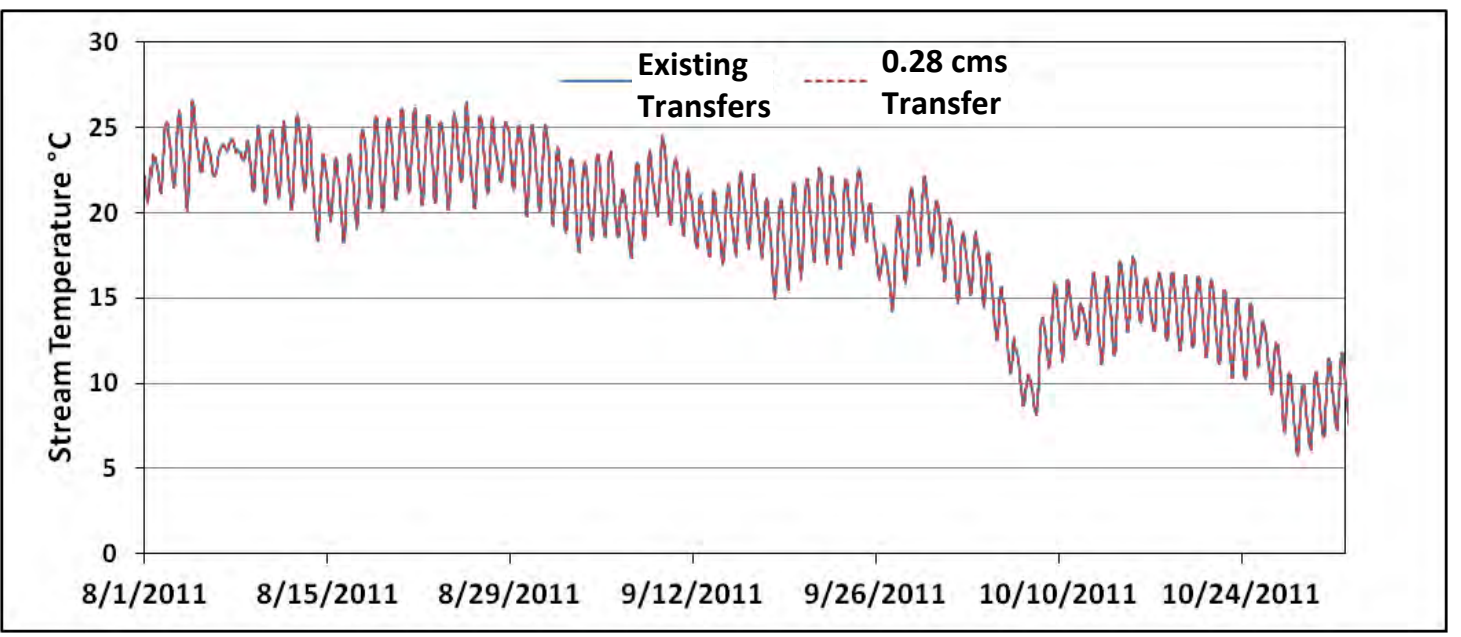

Figure B-18: Existing transfers versus $0.28 \mathrm{cms}$ transfers from CANAL diversion stream temperatures at RKM 2.69 near the mouth of Walker Lake. 


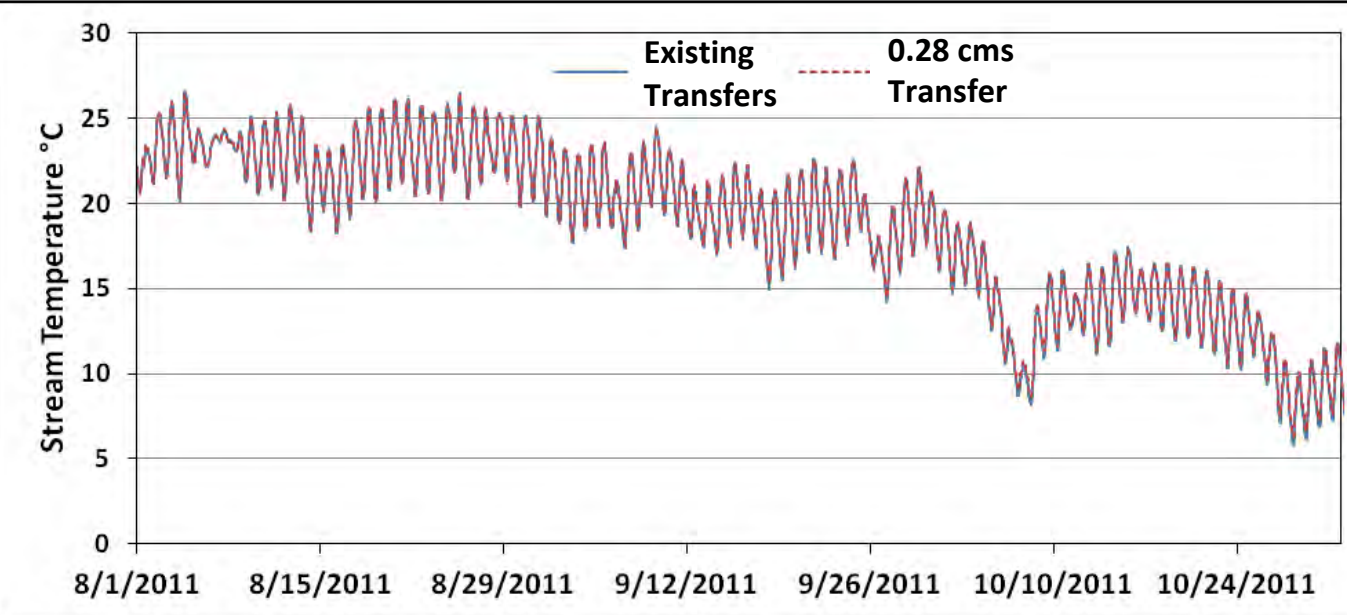

Figure B-19: Existing transfers versus $0.28 \mathrm{cms}$ transfers from SARONI diversion stream temperatures at RKM 2.69 near the mouth of Walker Lake.

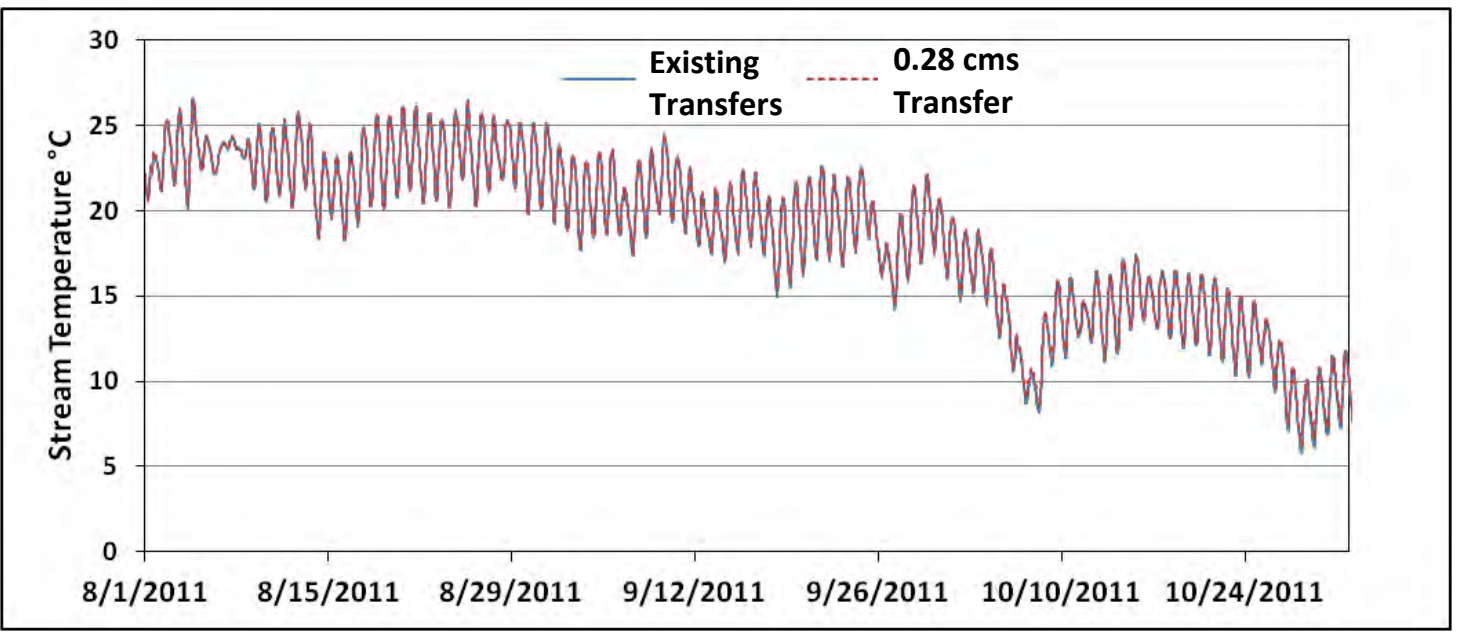

Figure B-20: Existing transfers versus $0.28 \mathrm{cms}$ transfers from GAGE diversion stream temperatures at RKM 2.69 near the mouth of Walker Lake. 


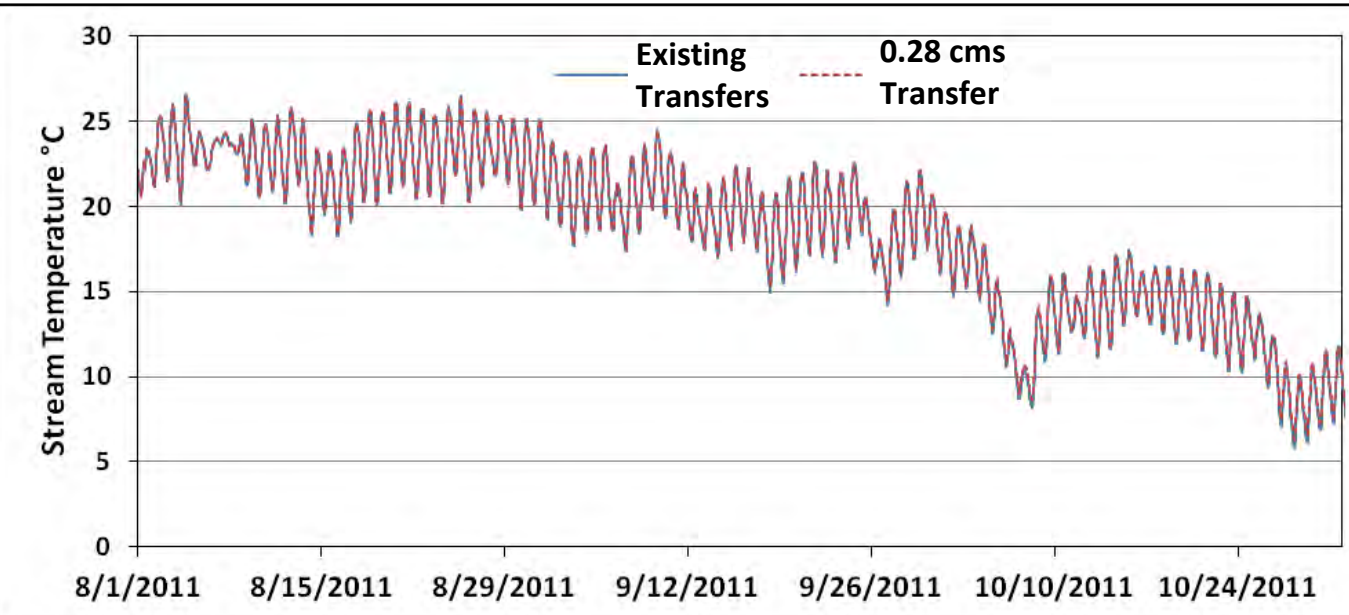

Figure B-21: Existing transfers versus $0.28 \mathrm{cms}$ transfers from COLONY diversion stream temperatures at RKM 2.69 near the mouth of Walker Lake.

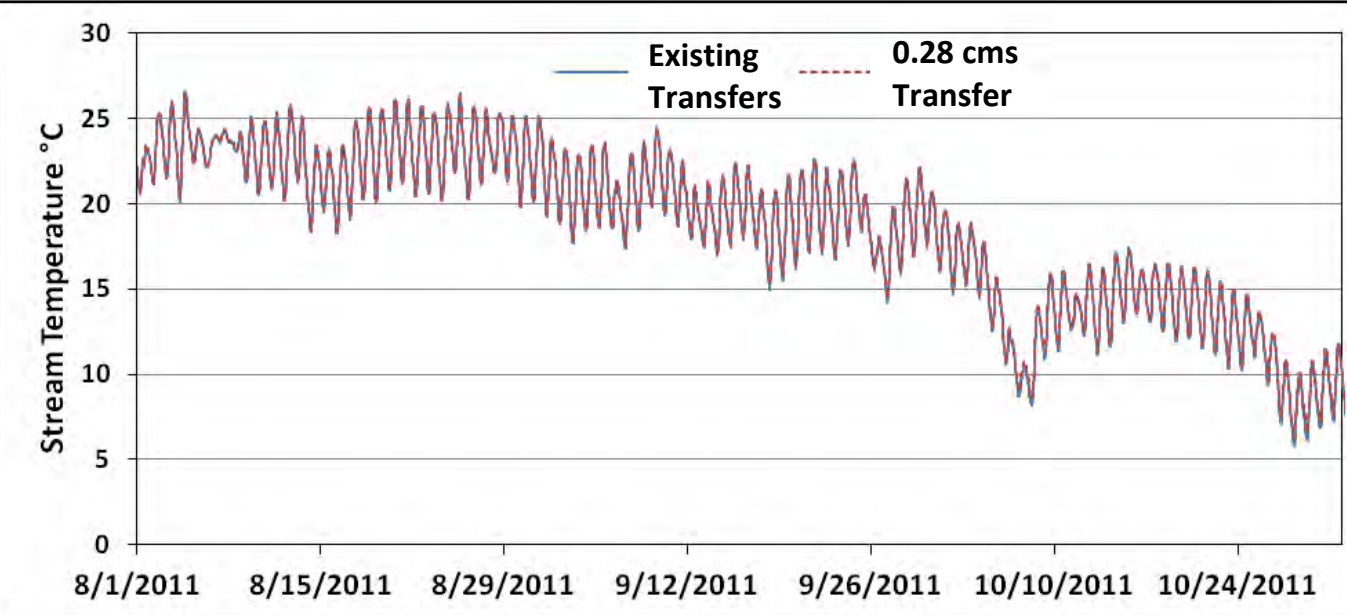

Figure B-22: Existing transfers versus $0.28 \mathrm{cms}$ transfers from TUNNEL diversion stream temperatures at RKM 2.69 near the mouth of Walker Lake. 


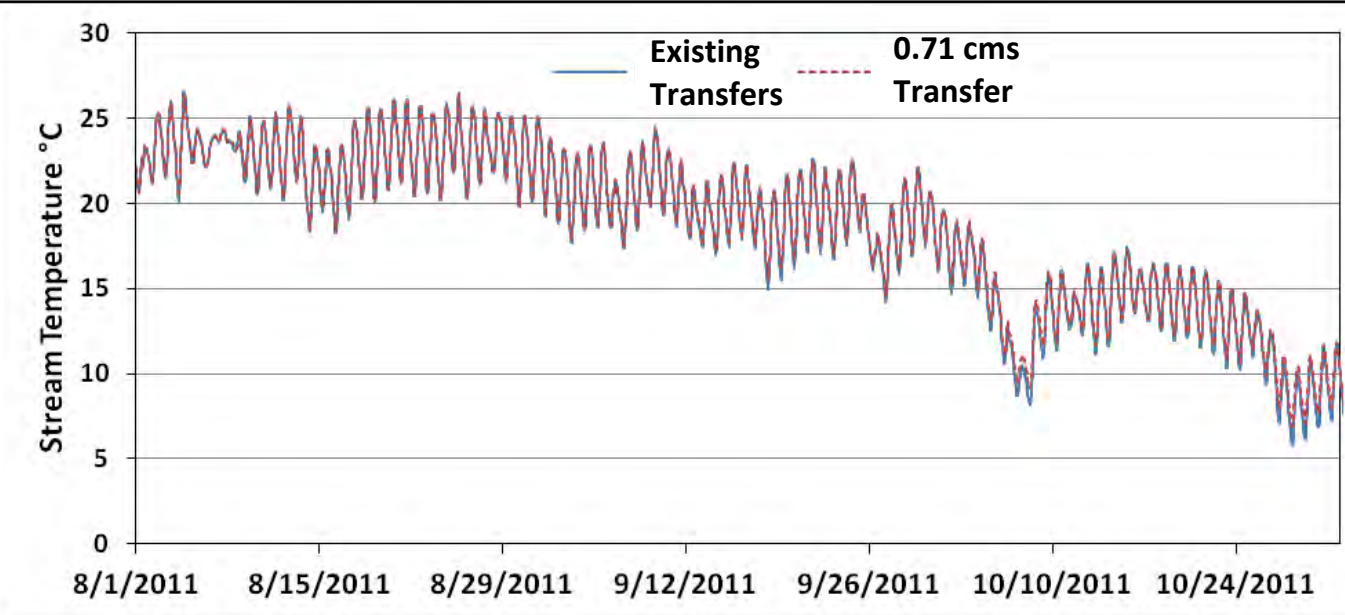

Figure B-23: Existing transfers versus $0.71 \mathrm{cms}$ transfers from Bridgeport Reservoir stream temperatures at RKM 2.69 near the mouth of Walker Lake.

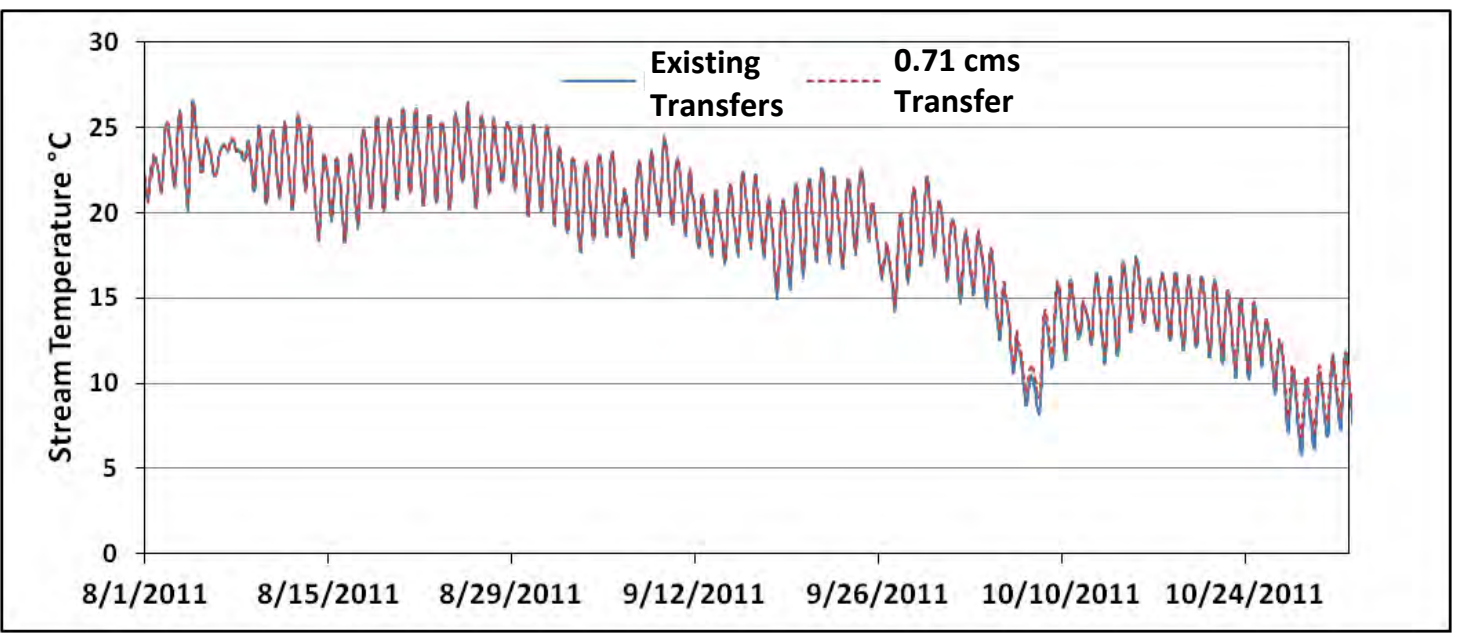

Figure B-24: Existing transfers versus $0.71 \mathrm{cms}$ transfers from Topaz Reservoir stream temperatures at RKM 2.69 near the mouth of Walker Lake. 


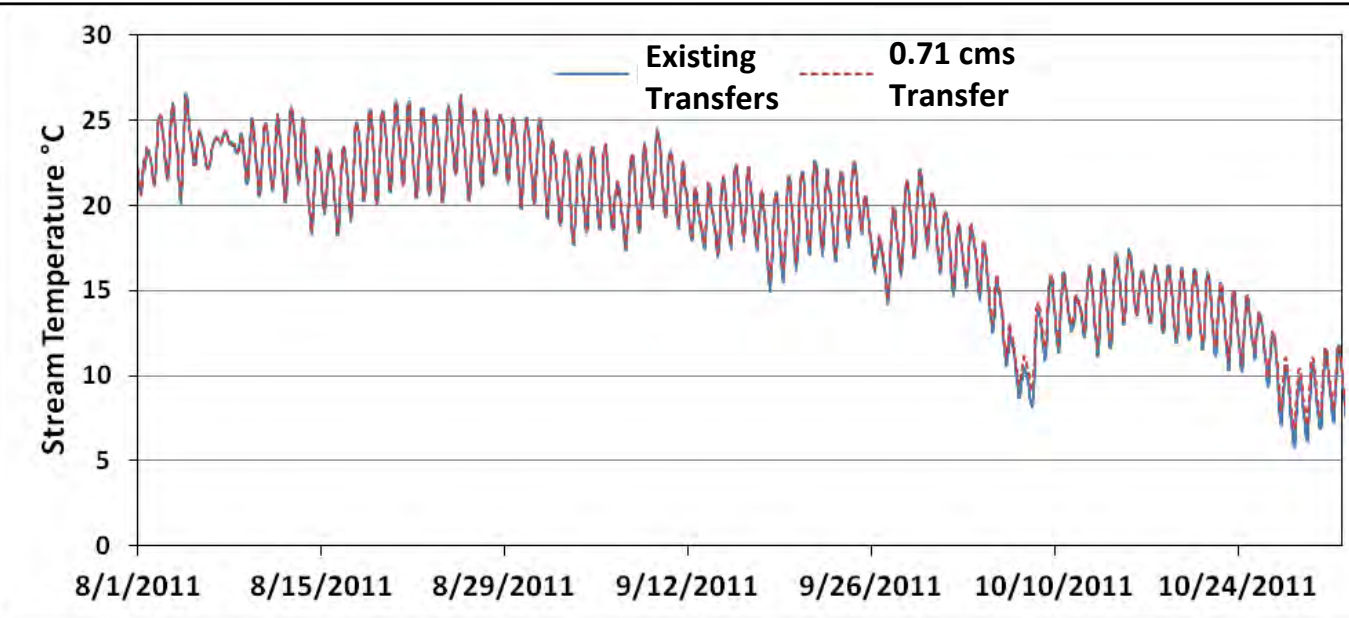

Figure B-25: Existing transfers versus $0.71 \mathrm{cms}$ transfers from SSWJD diversion stream temperatures at RKM 2.69 near the mouth of Walker Lake.

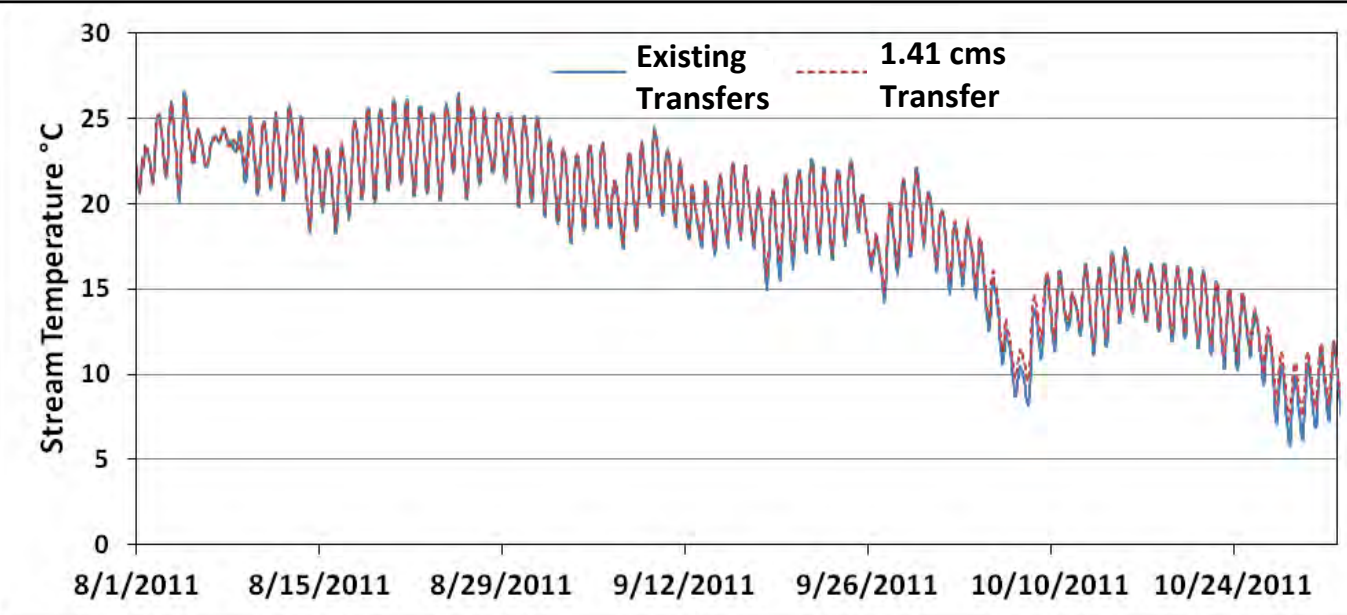

Figure B-26: Existing transfers versus $1.41 \mathrm{cms}$ transfers from Bridgeport Reservoir stream temperatures at RKM 2.69 near the mouth of Walker Lake. 


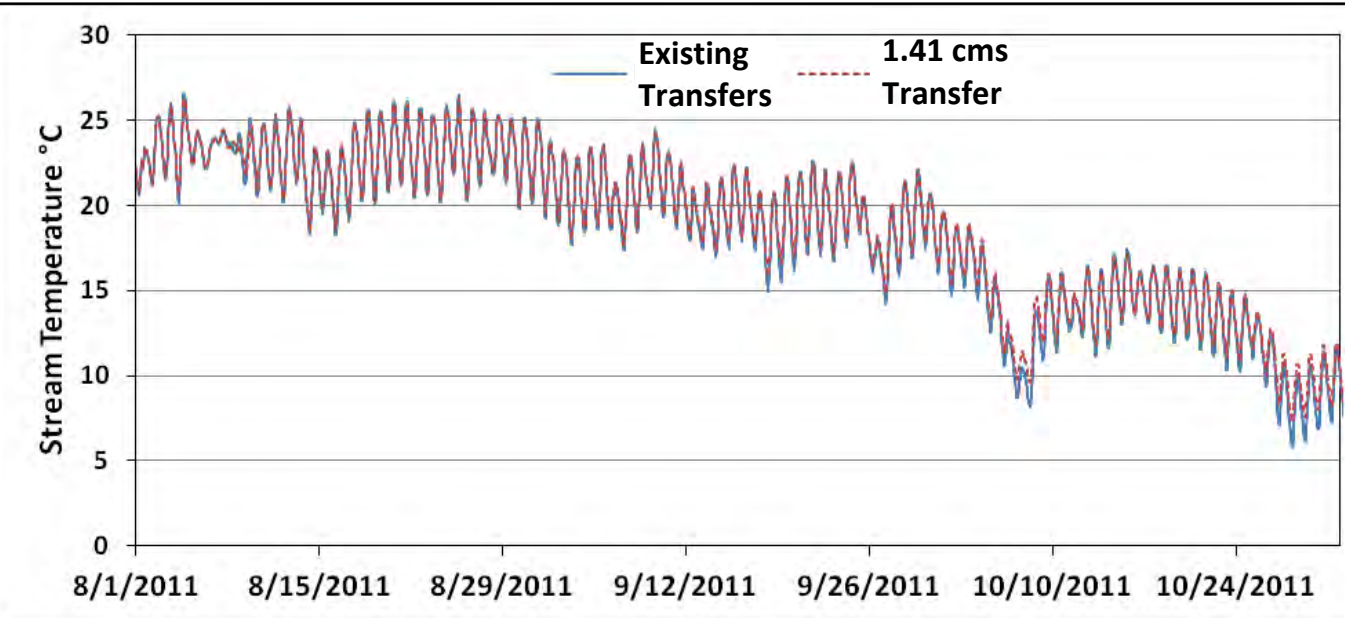

Figure B-27: Existing transfers versus $1.41 \mathrm{cms}$ transfers from Topaz Reservoir stream temperatures at RKM 2.69 near the mouth of Walker Lake.

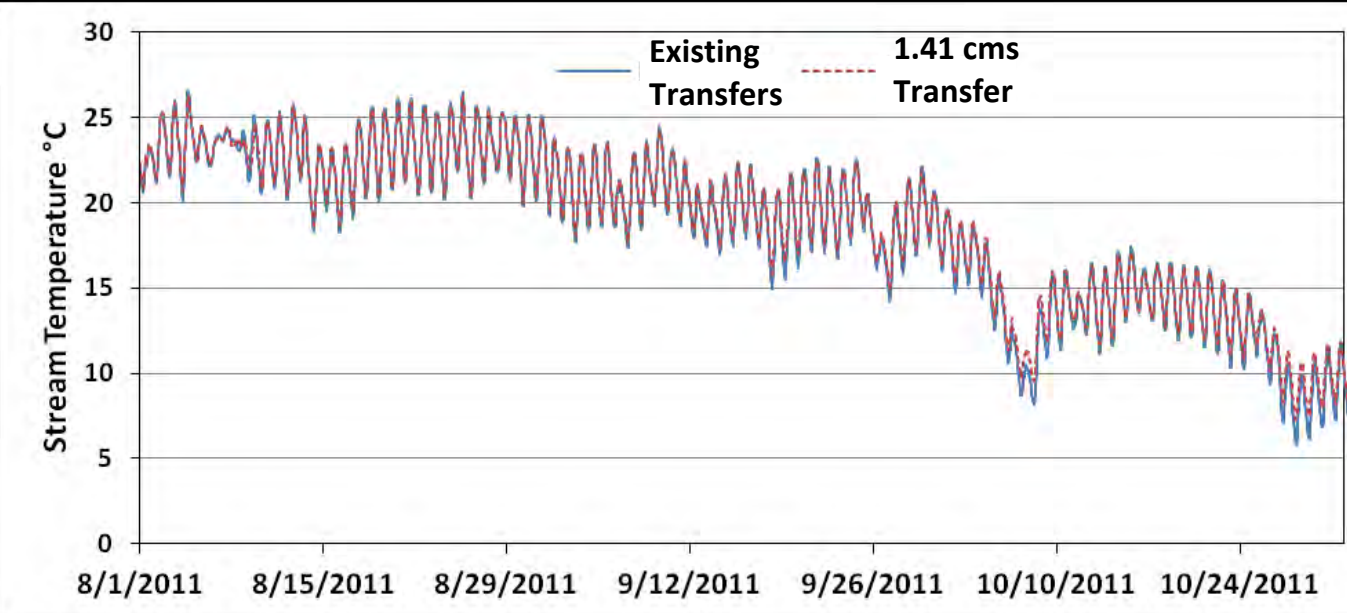

Figure B-28: Existing transfers versus $1.41 \mathrm{cms}$ transfers from SSWJD diversion stream temperatures at RKM 2.69 near the mouth of Walker Lake. 
Zero Diversion Scenarios: all diversions during the irrigation season turned off, singly, for each diversion.

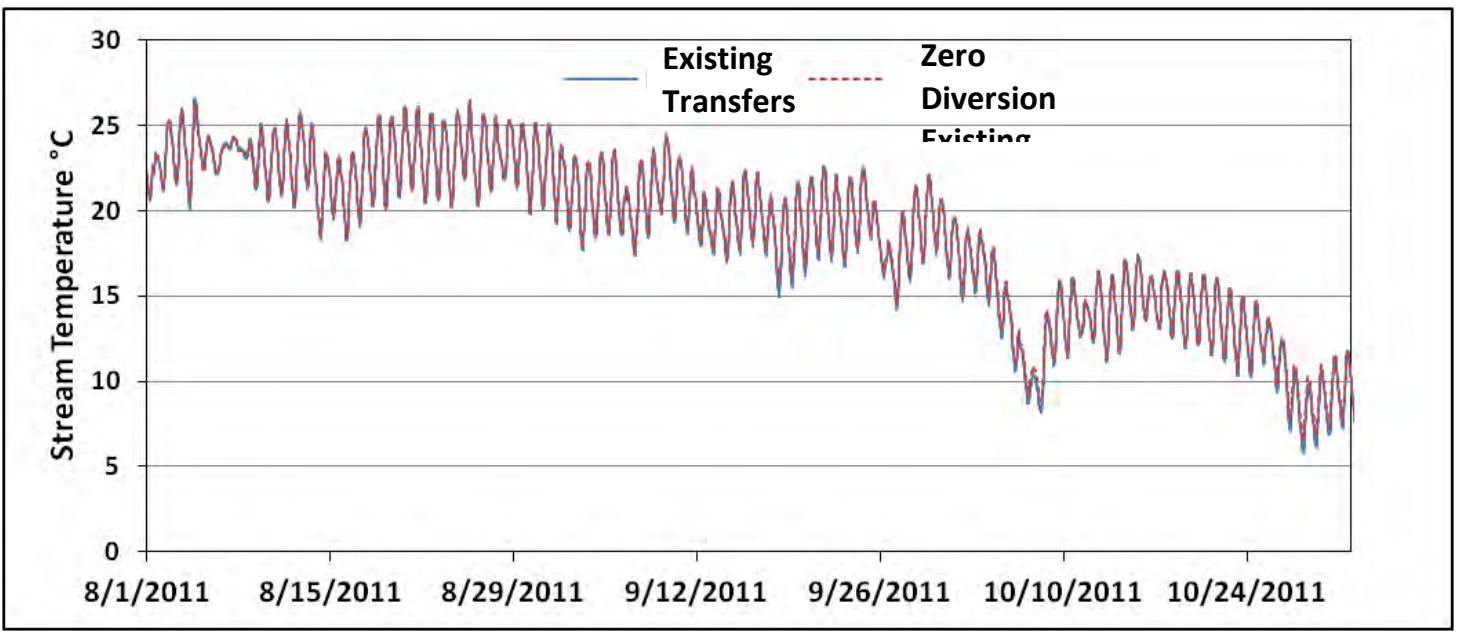

Figure B-29: Existing transfers versus zero diversions from BNGHH diversion stream temperatures at RKM 2.69 near the mouth of Walker Lake.

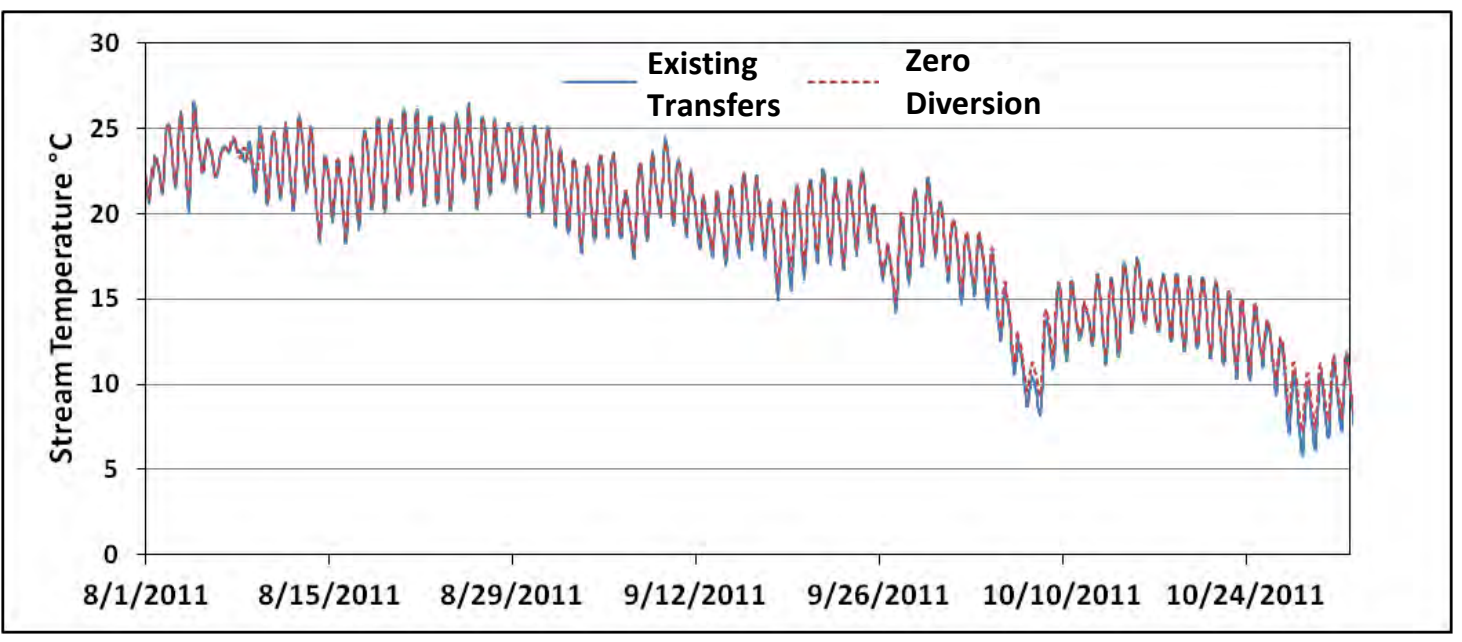

Figure B-30: Existing transfers versus zero diversions from FOX diversion stream temperatures at RKM 2.69 near the mouth of Walker Lake. 


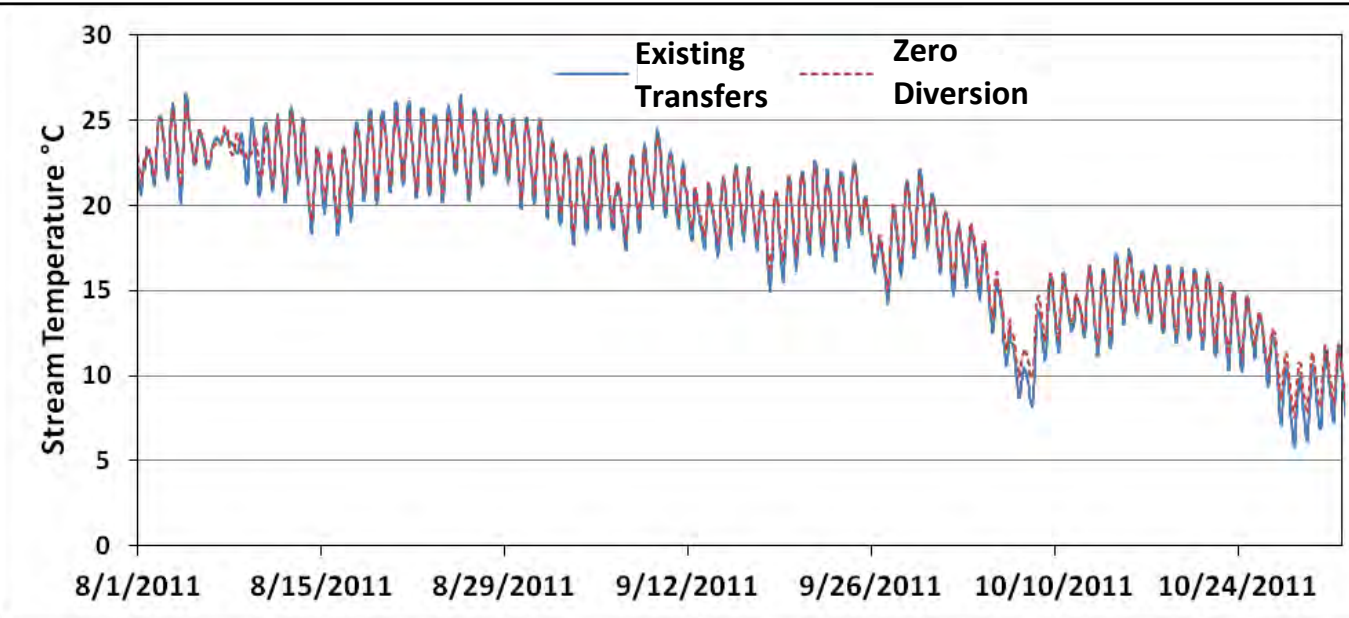

Figure B-31: Existing transfers versus zero diversions from MCCAMP diversion stream temperatures at RKM 2.69 near the mouth of Walker Lake.

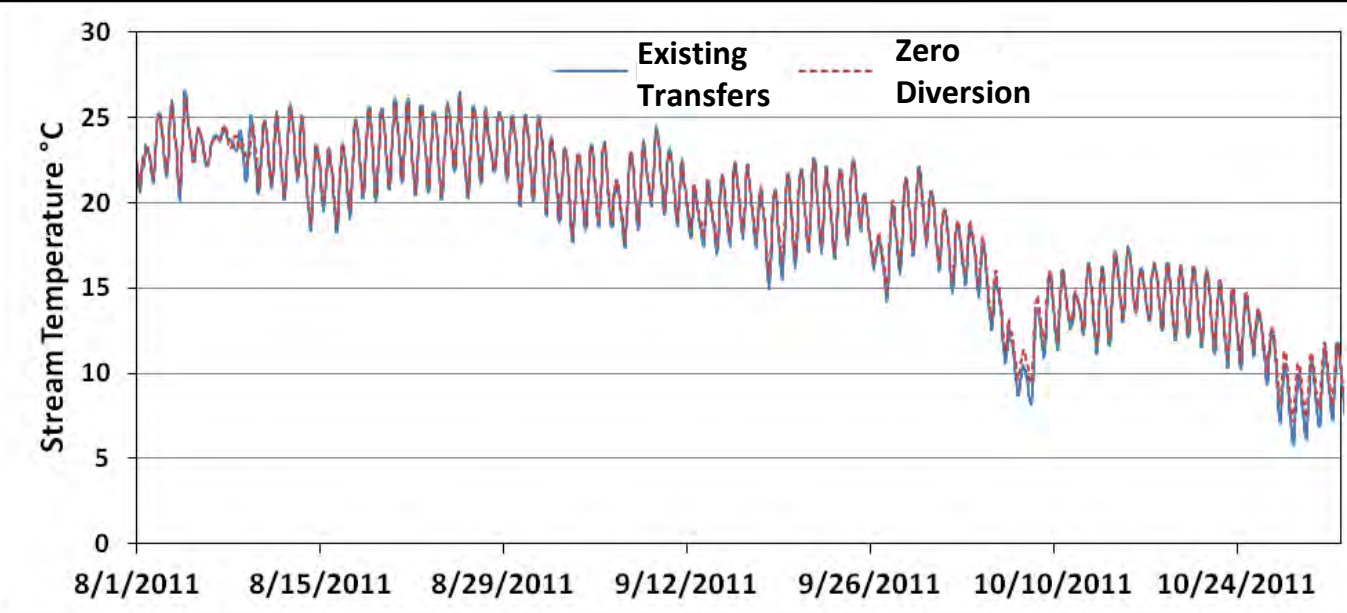

Figure B-32: Existing transfers versus zero diversions from SSWJD diversion stream temperatures at RKM 2.69 near the mouth of Walker Lake. 


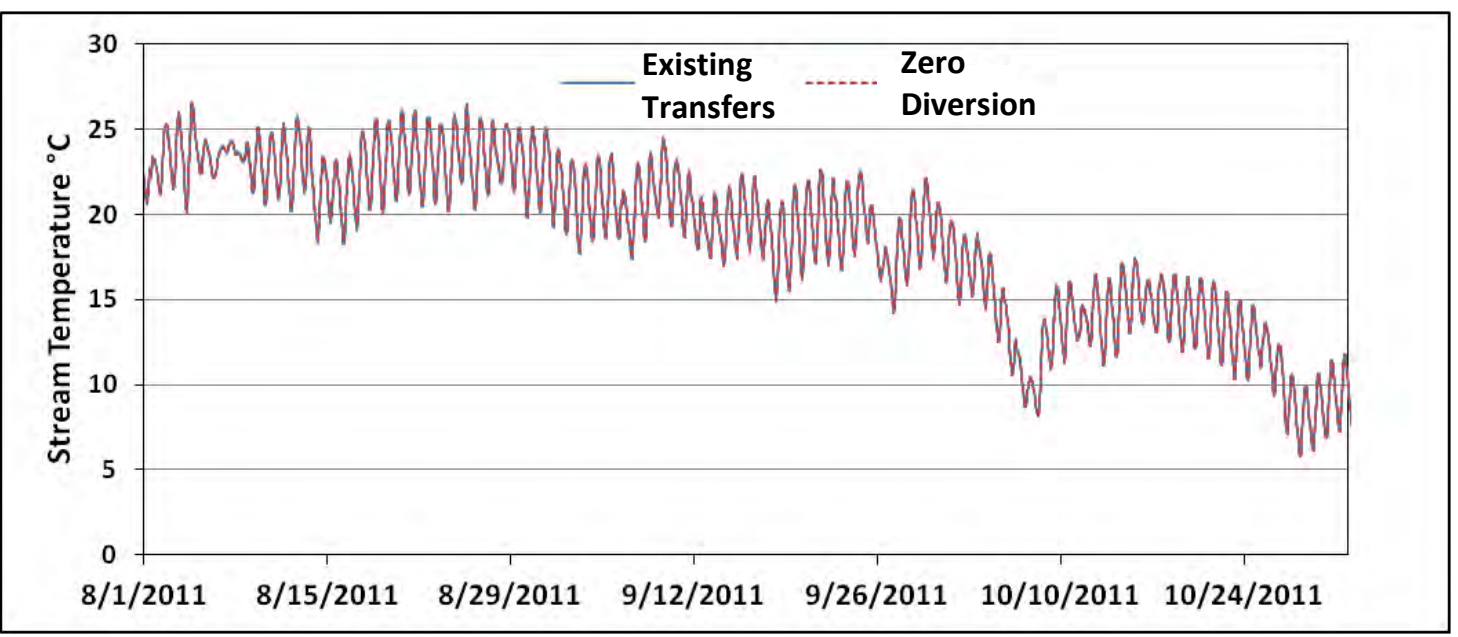

Figure B-33: Existing transfers versus zero diversions from CANAL diversion stream temperatures at RKM 2.69 near the mouth of Walker Lake.

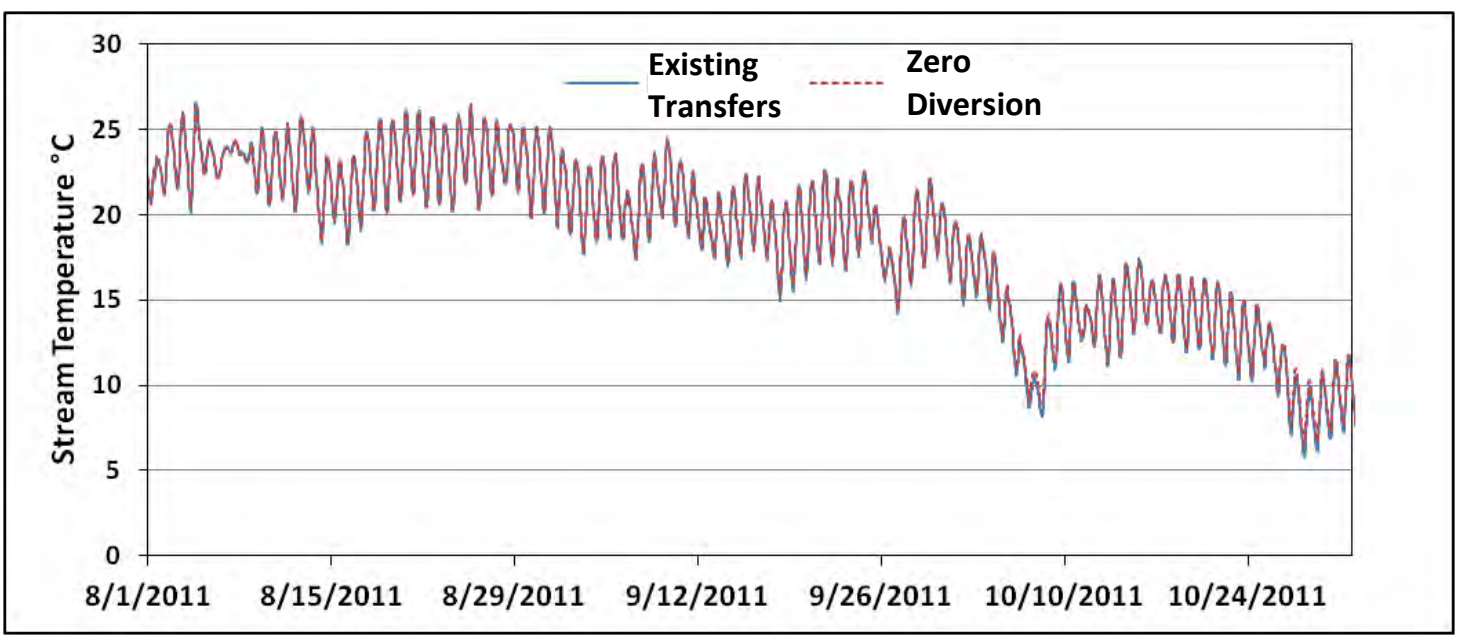

Figure B-34: Existing transfers versus zero diversions from SARONI diversion stream temperatures at RKM 2.69 near the mouth of Walker Lake. 


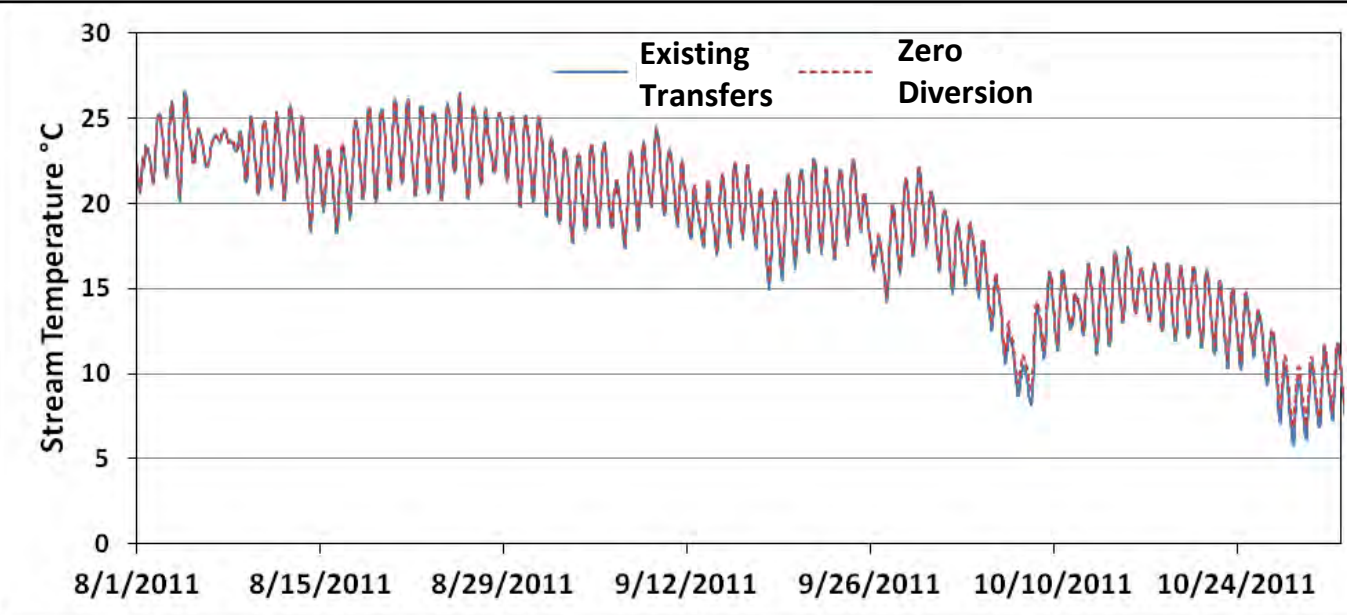

Figure B-35: Existing transfers versus zero diversions from GAGE diversion stream temperatures at RKM 2.69 near the mouth of Walker Lake.

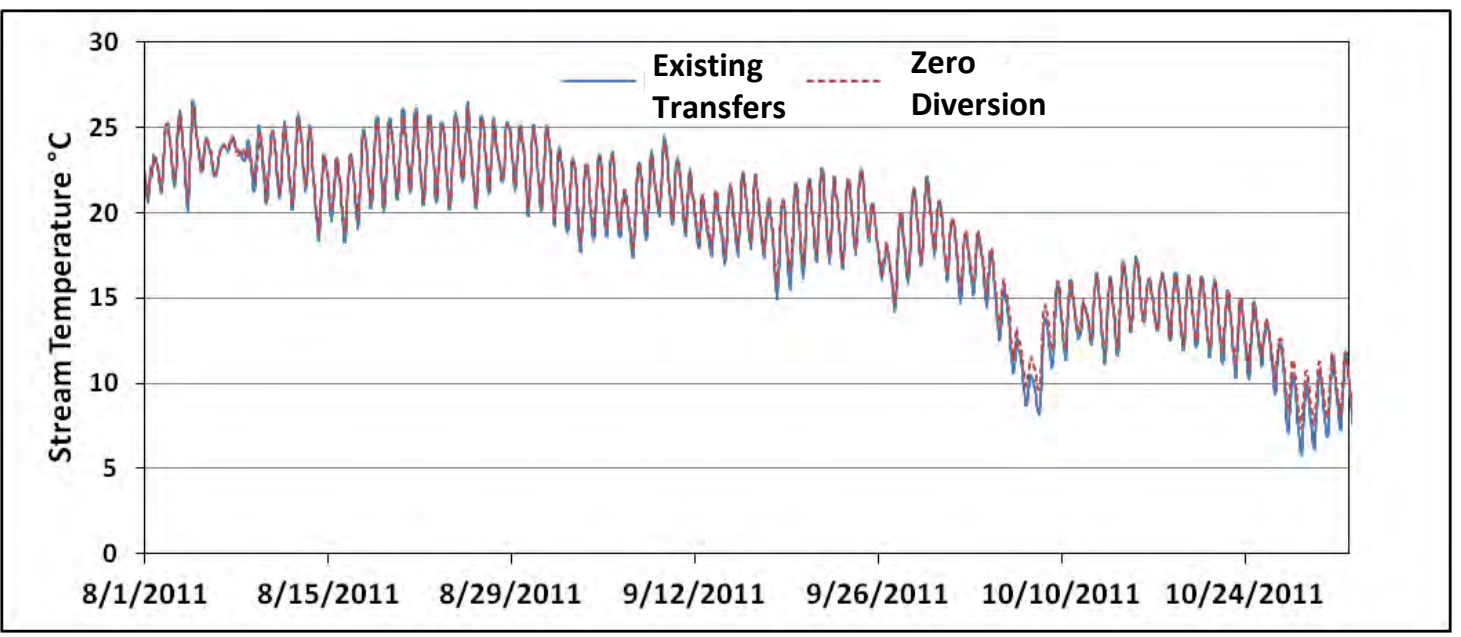

Figure B-36: Existing transfers versus zero diversions from COLONY diversion stream temperatures at RKM 2.69 near the mouth of Walker Lake. 


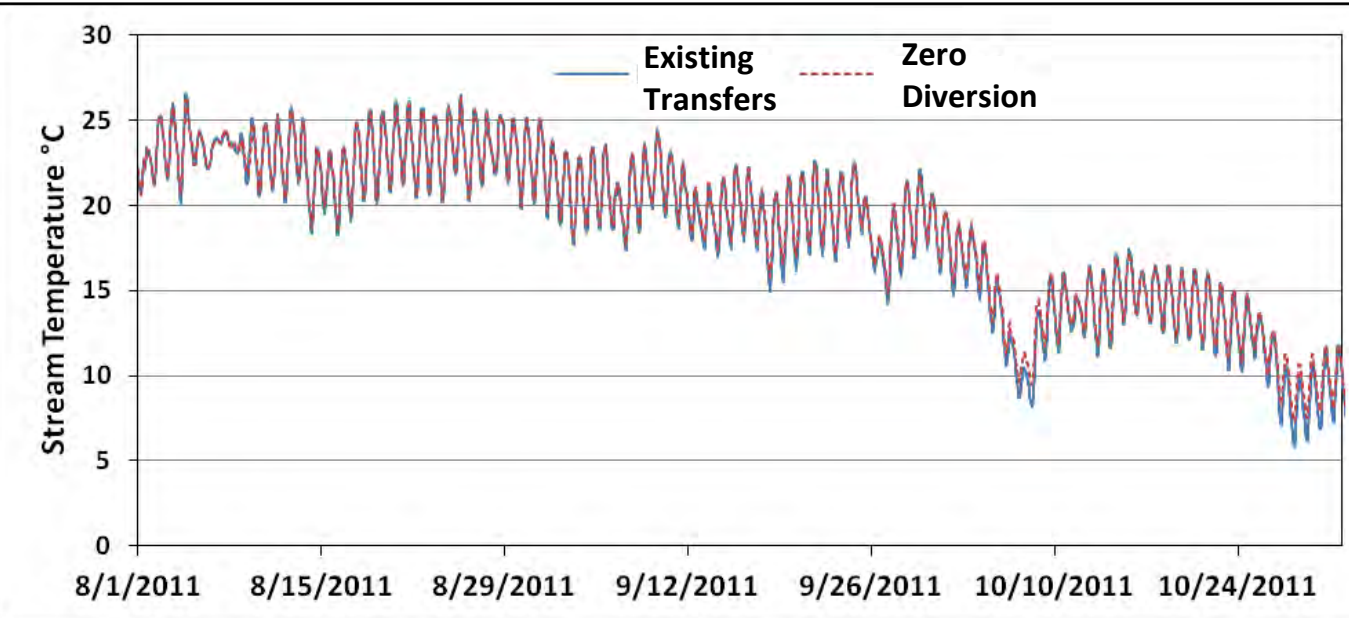

Figure B-37: Existing transfers versus zero diversions from TUNNEL diversion stream temperatures at RKM 2.69 near the mouth of Walker Lake.

No Diversion Scenario: All diversions turned off for all diversions combined in one run.

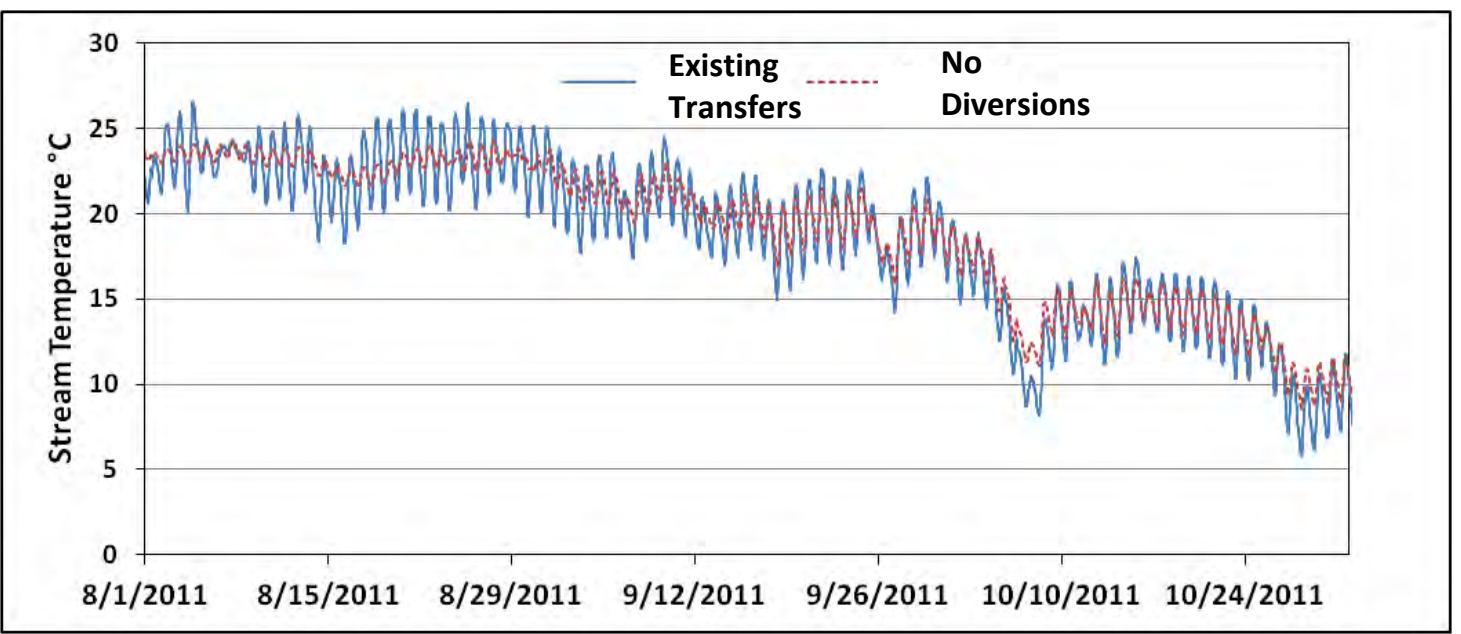

Figure B-38: Existing transfers versus no diversions from all diversions (combined) stream temperatures at RKM 2.69 near the mouth of Walker Lake. 
Sensitivity Anaylses:

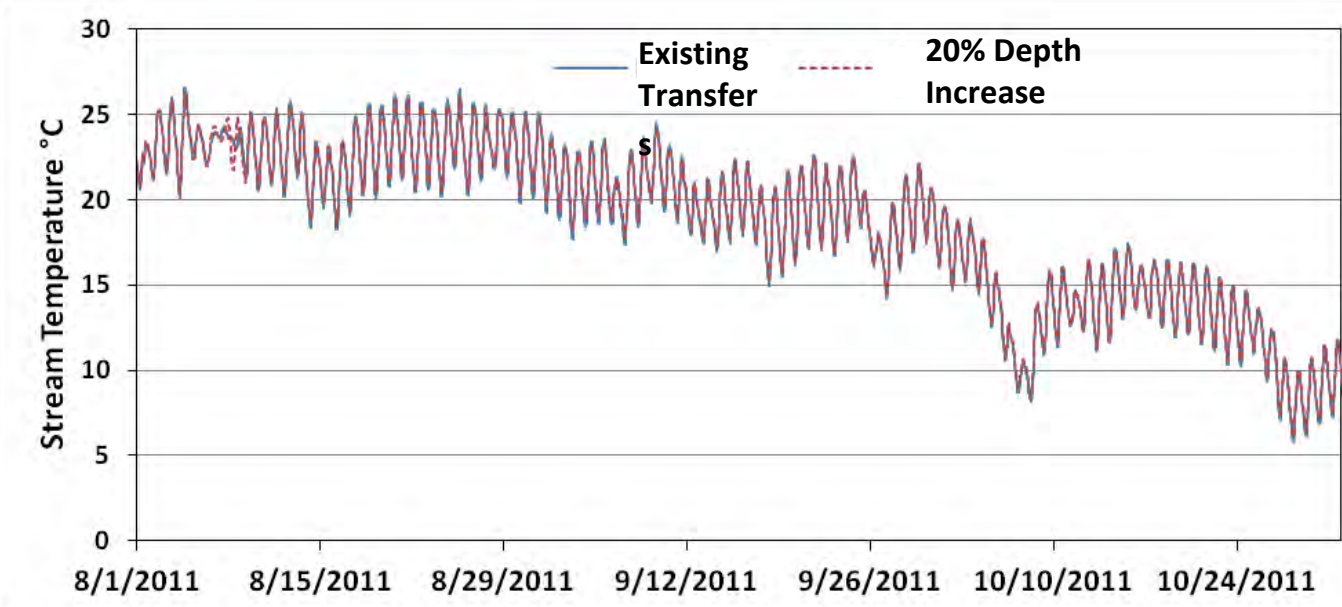

Figure B-39: Sensitivity analysis of Existing transfers with $0.94 \mathrm{~m}$ depth versus Existing transfers with $1.18 \mathrm{~m}$ depth (20\% increase) stream temperatures at RKM 2.69 near the mouth of Walker Lake.

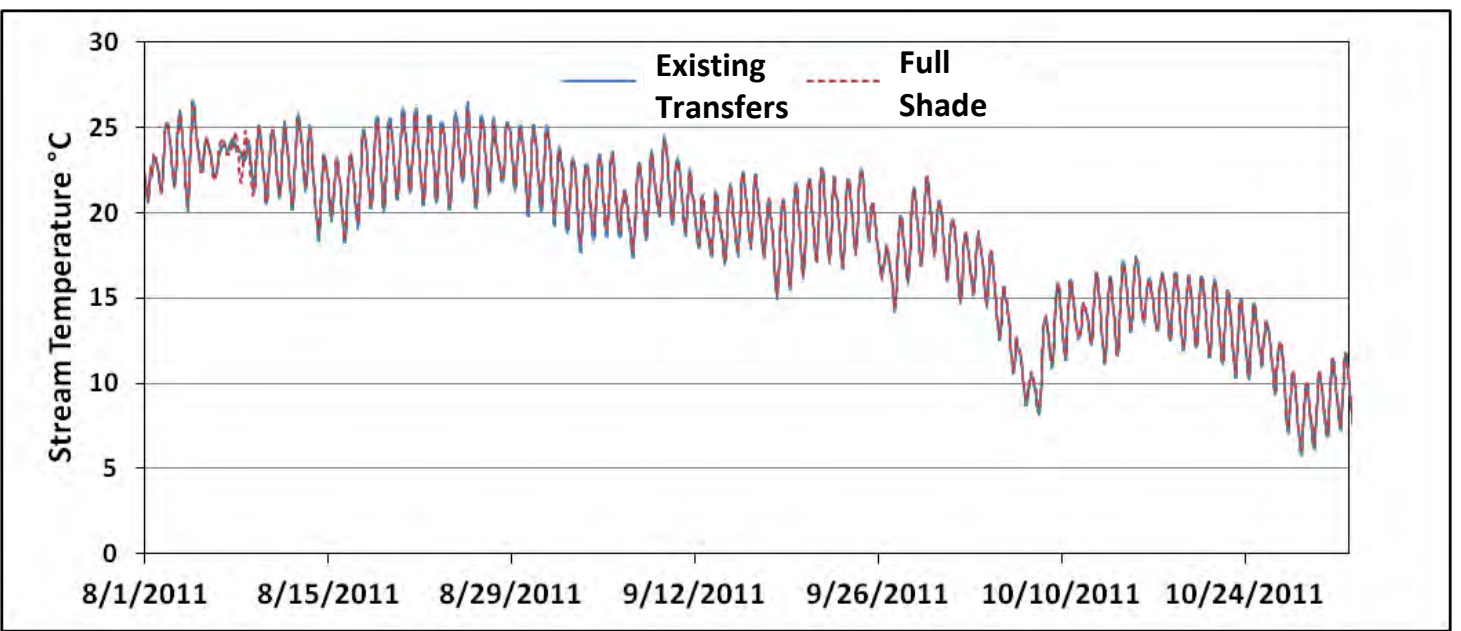

Figure B-40: Sensitivity analysis of Existing transfers scenario versus Existing transfers with full shade stream temperatures at RKM 2.69 near the mouth of Walker Lake. 


\section{Plots}

Calibration plot: measured versus modeled stream temperature.

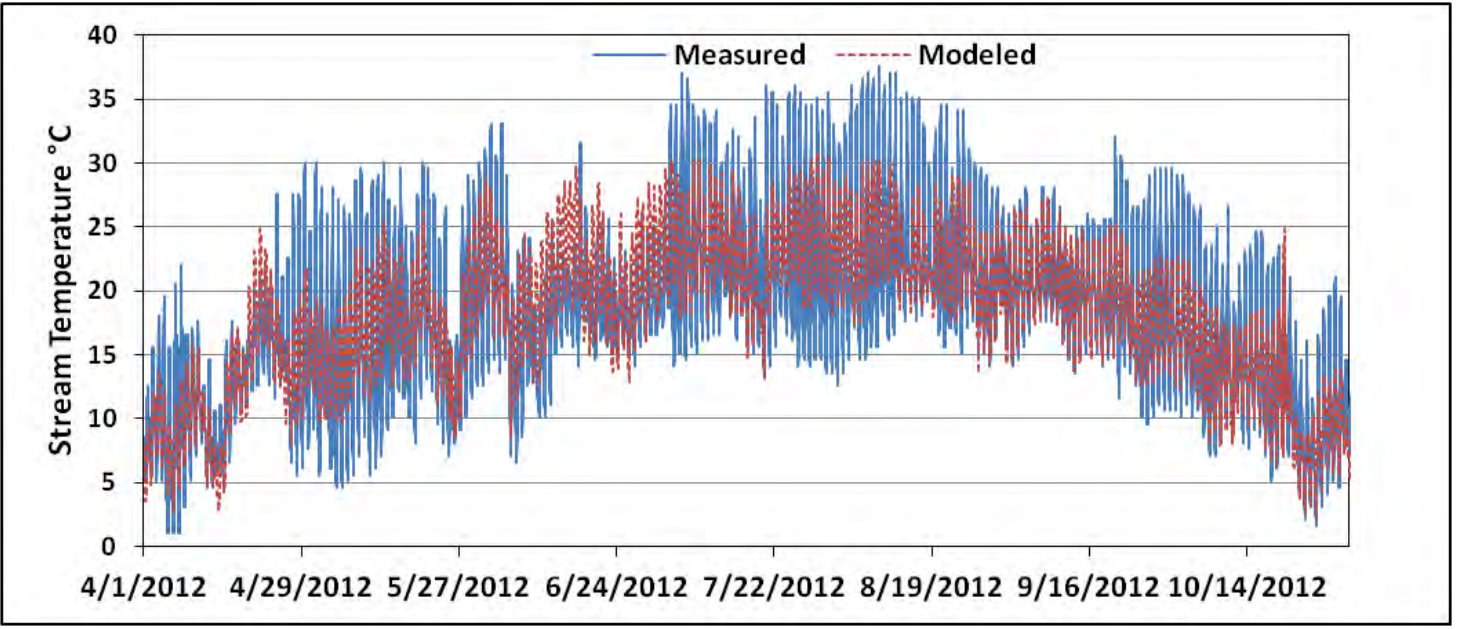

Figure B-41: Measured versus modeled stream temperatures at RKM 2.69 near the mouth of Walker Lake.

Historical Conditions scenario versus existing transfers at Bridgeport Reservoir, BNGHH, SSWJD, GAGE, and COLONY diversion, simulated as one run.

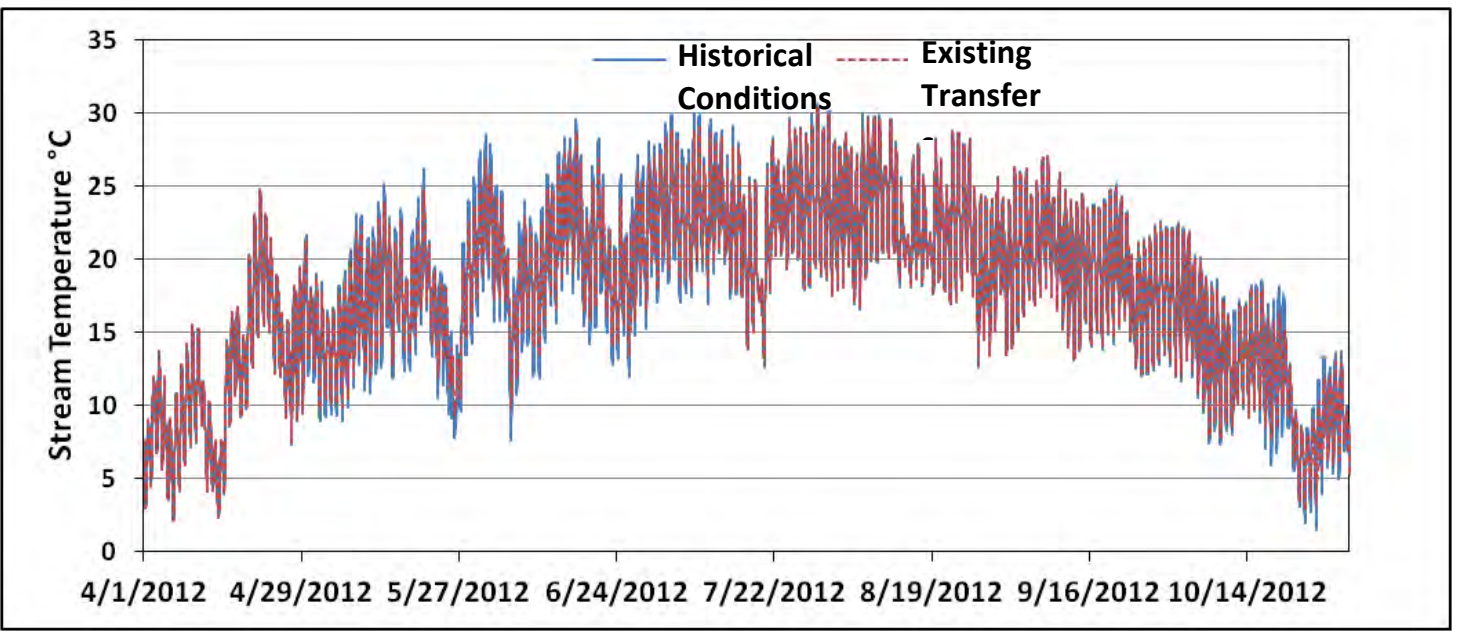

Figure B-42: Historical Conditions versus existing transfers stream temperatures at RKM 2.69 near the mouth of Walker Lake. 
Water Transfer Scenario Runs: these plots show the different water right acquisitions of $0.14,0.28,0.71$, and $1.41 \mathrm{cms}$ added at each diversion or reservoir in addition to their existing transfers versus the single existing transfers scenario.

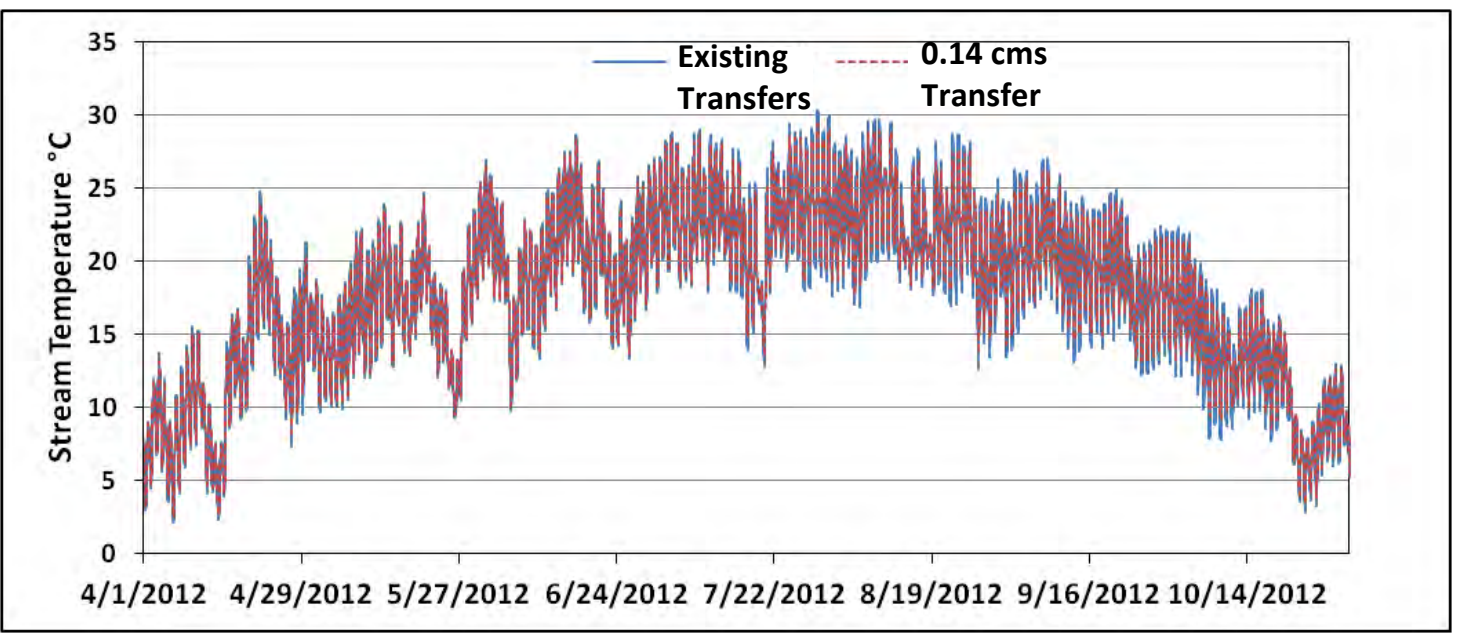

Figure B-43: Existing transfers versus $0.14 \mathrm{cms}$ transfers from Bridgeport Reservoir stream temperatures at RKM 2.69 near the mouth of Walker Lake.

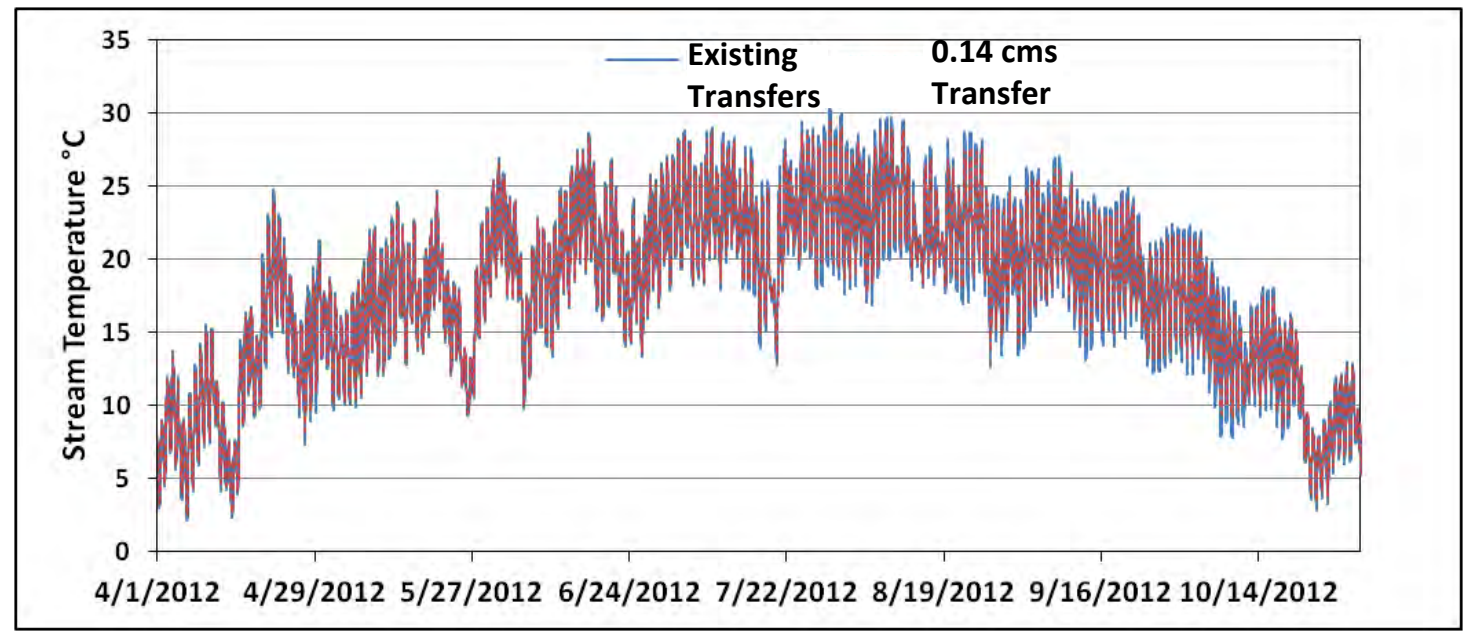

Figure B-44: Existing transfers versus $0.14 \mathrm{cms}$ transfers from BNGHH diversion stream temperatures at RKM 2.69 near the mouth of Walker Lake. 


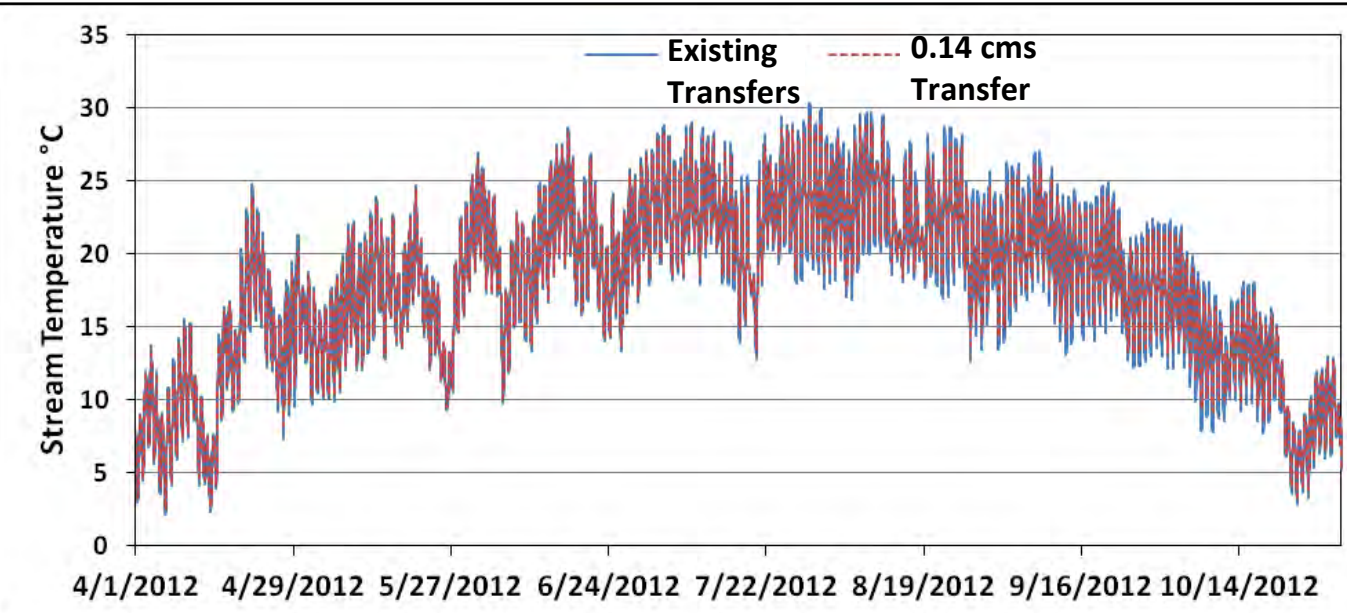

Figure B-45: Existing transfers versus $0.14 \mathrm{cms}$ transfers from FOX diversion stream temperatures at RKM 2.69 near the mouth of Walker Lake.

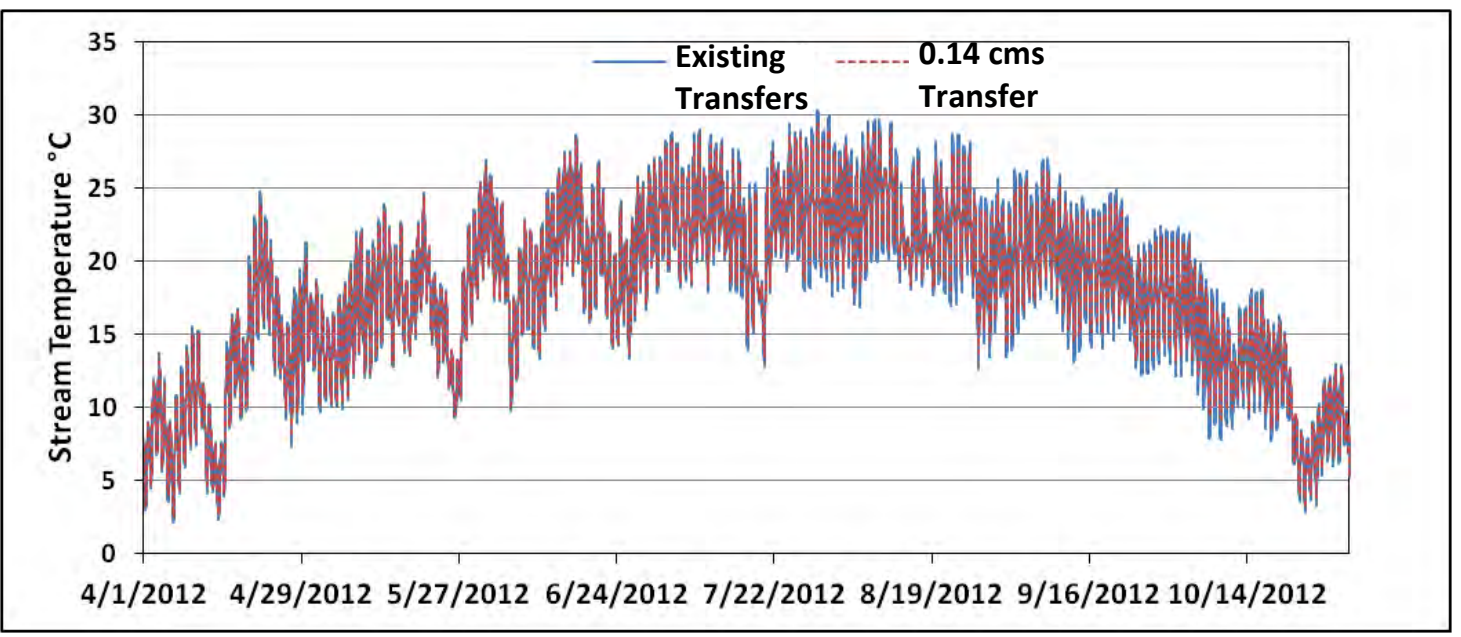

Figure B-46: Existing transfers versus $0.14 \mathrm{cms}$ transfers from MCCAMP diversion stream temperatures at RKM 2.69 near the mouth of Walker Lake. 


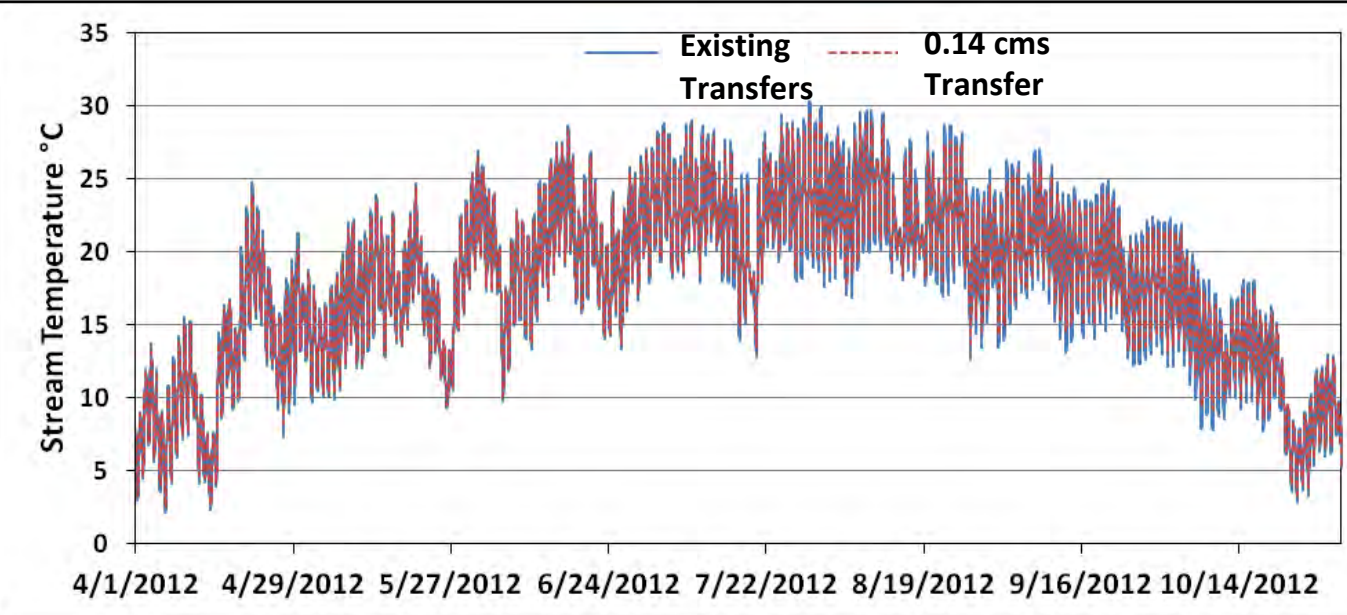

Figure B-47: Existing transfers versus $0.14 \mathrm{cms}$ transfers from SSWJD diversion stream temperatures at RKM 2.69 near the mouth of Walker Lake.

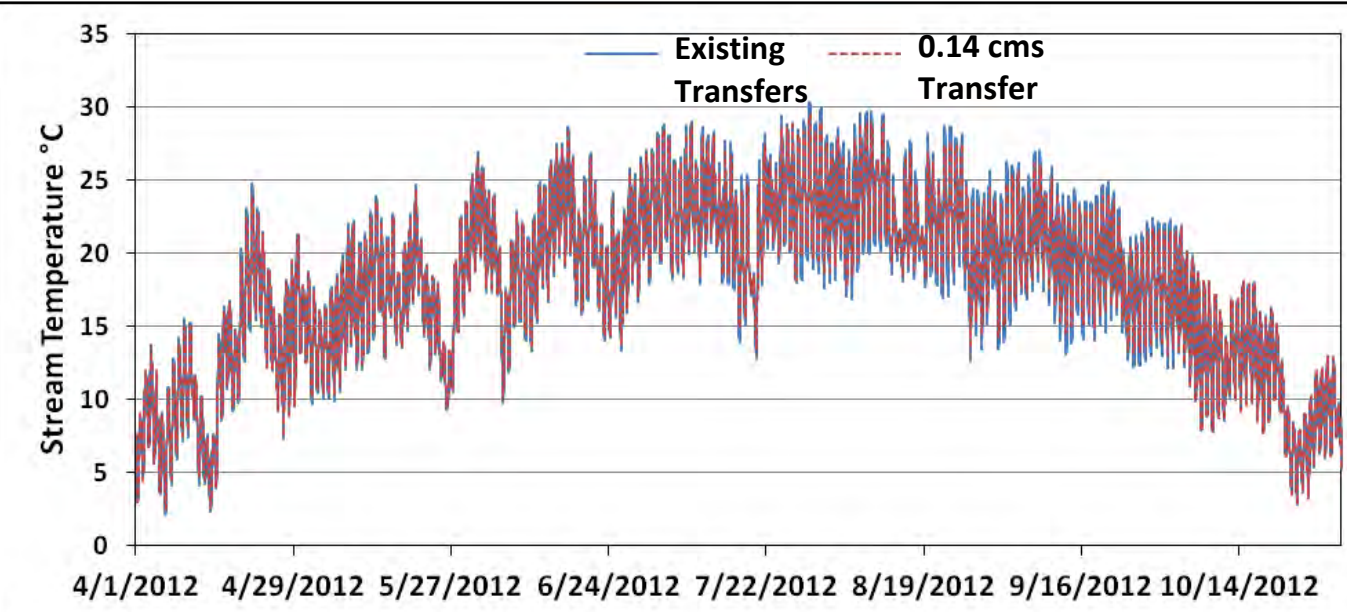

Figure B-48: Existing transfers versus $0.14 \mathrm{cms}$ transfers from CANAL diversion stream temperatures at RKM 2.69 near the mouth of Walker Lake. 


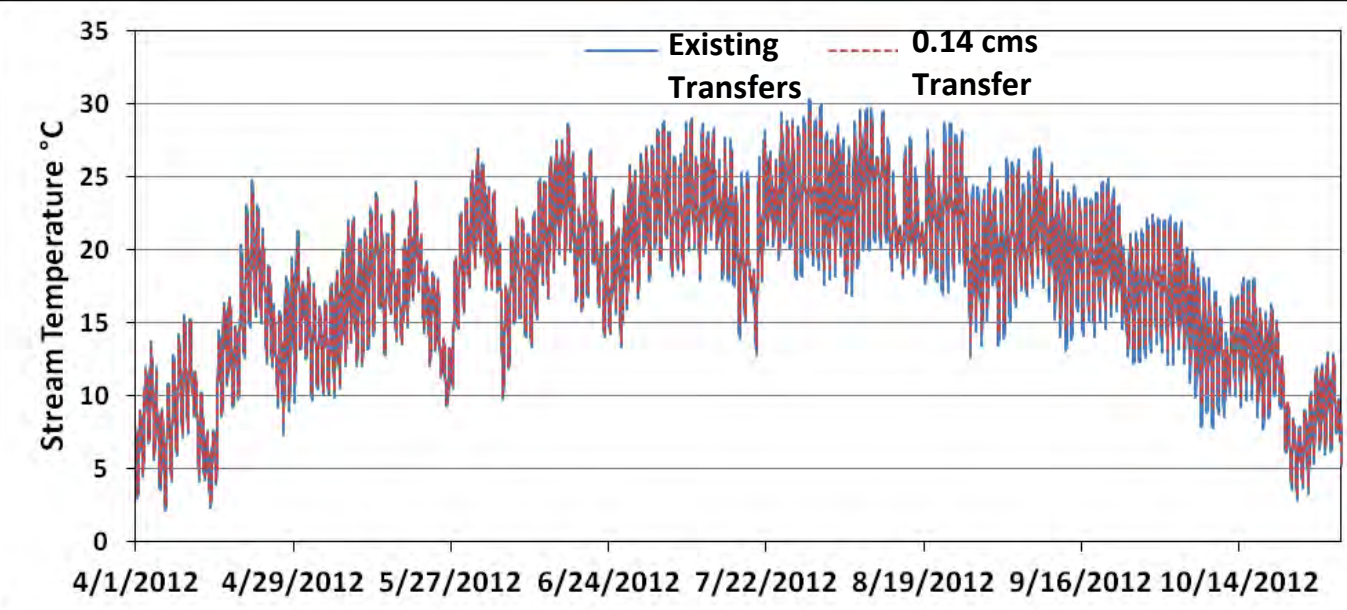

Figure B-49: Existing transfers versus $0.14 \mathrm{cms}$ transfers from SARONI diversion stream temperatures at RKM 2.69 near the mouth of Walker Lake.

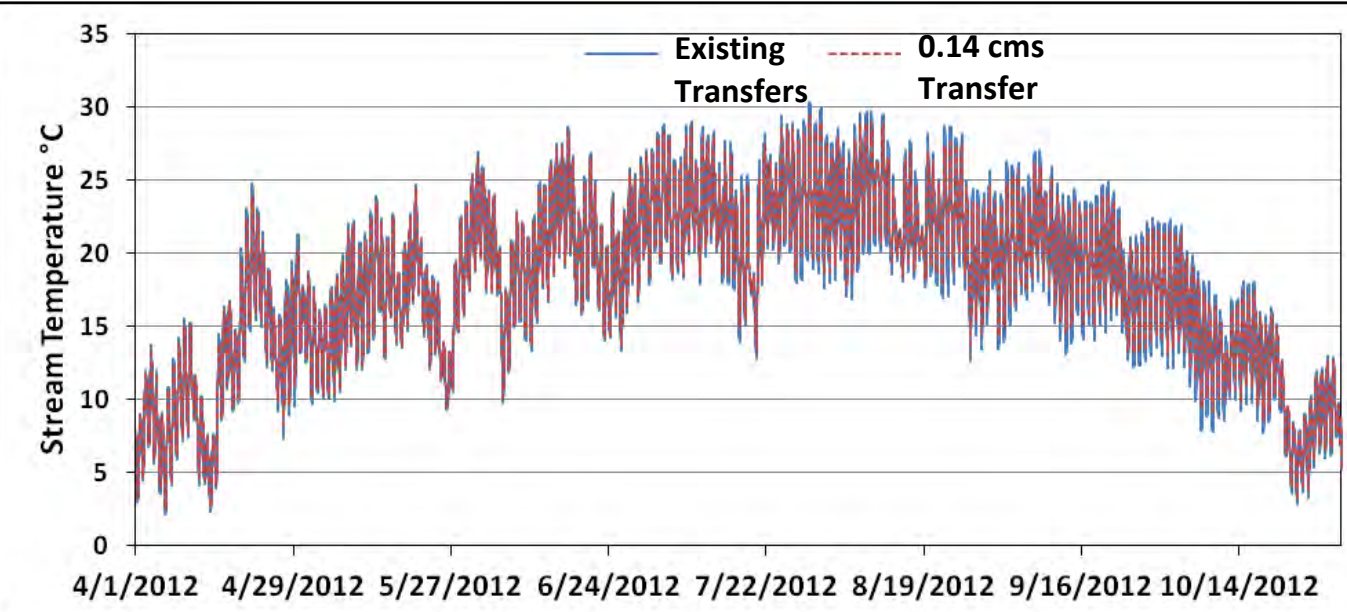

Figure B-50: Existing transfers versus $0.14 \mathrm{cms}$ transfers from GAGE diversion stream temperatures at RKM 2.69 near the mouth of Walker Lake. 


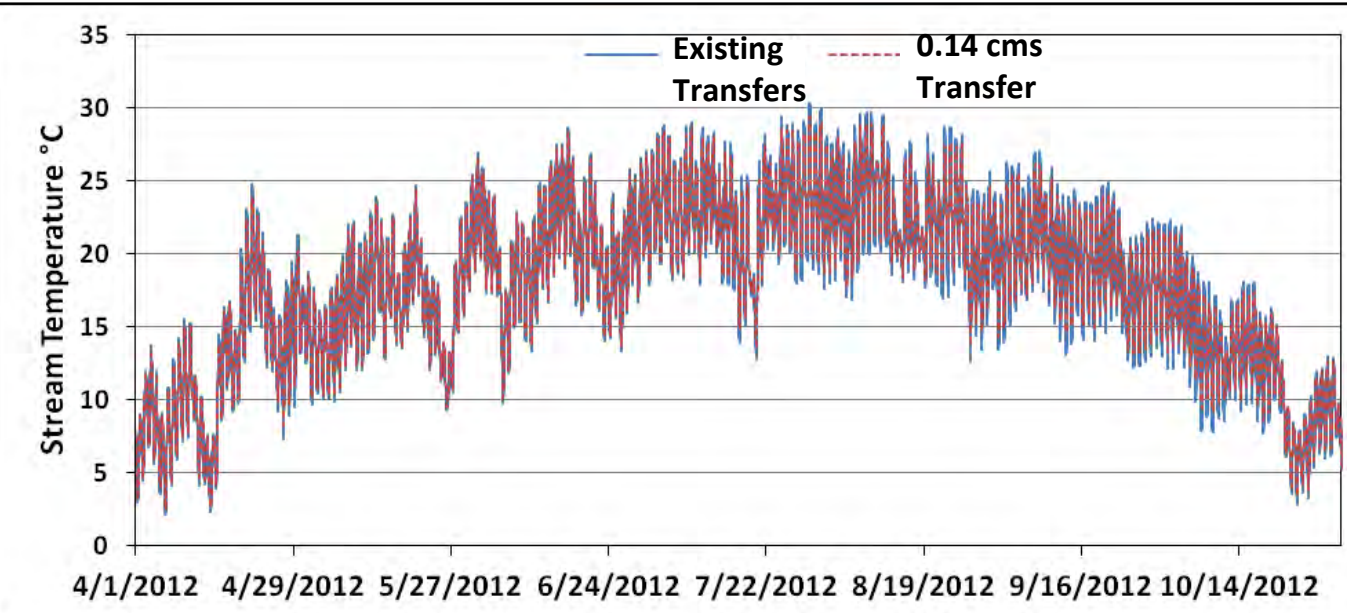

Figure B-51: Existing transfers versus $0.14 \mathrm{cms}$ transfers from COLONY diversion stream temperatures at RKM 2.69 near the mouth of Walker Lake.

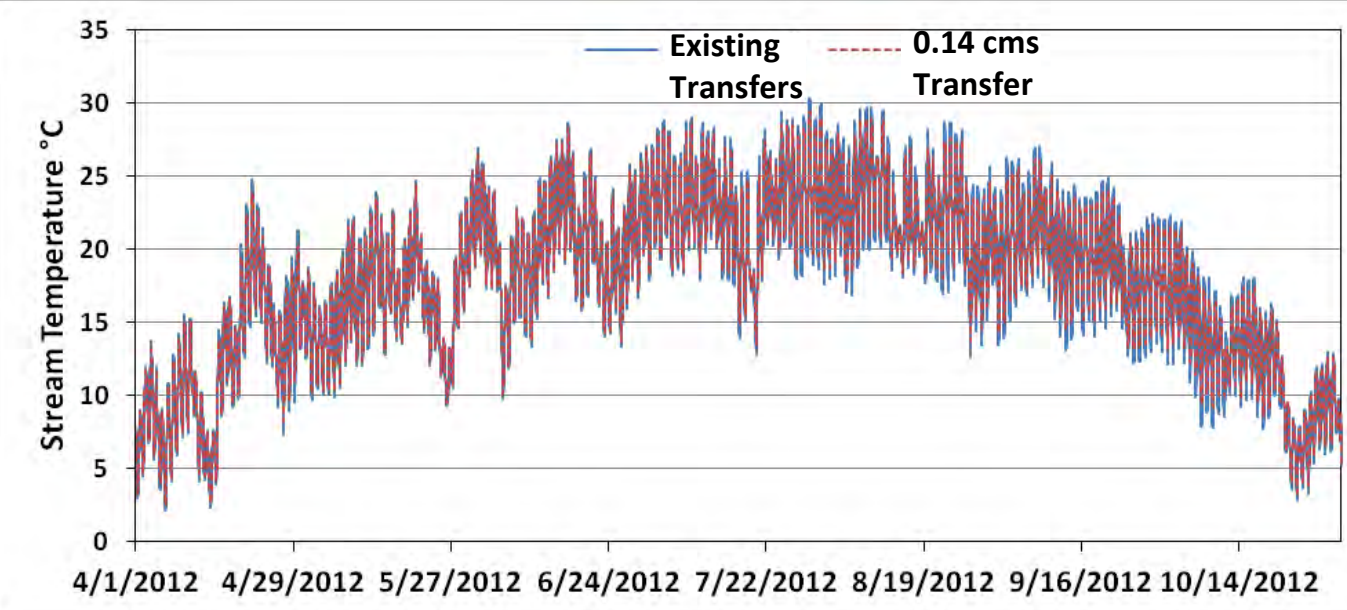

Figure B-52: Existing transfers versus $0.14 \mathrm{cms}$ transfers from TUNNEL diversion stream temperatures at RKM 2.69 near the mouth of Walker Lake. 


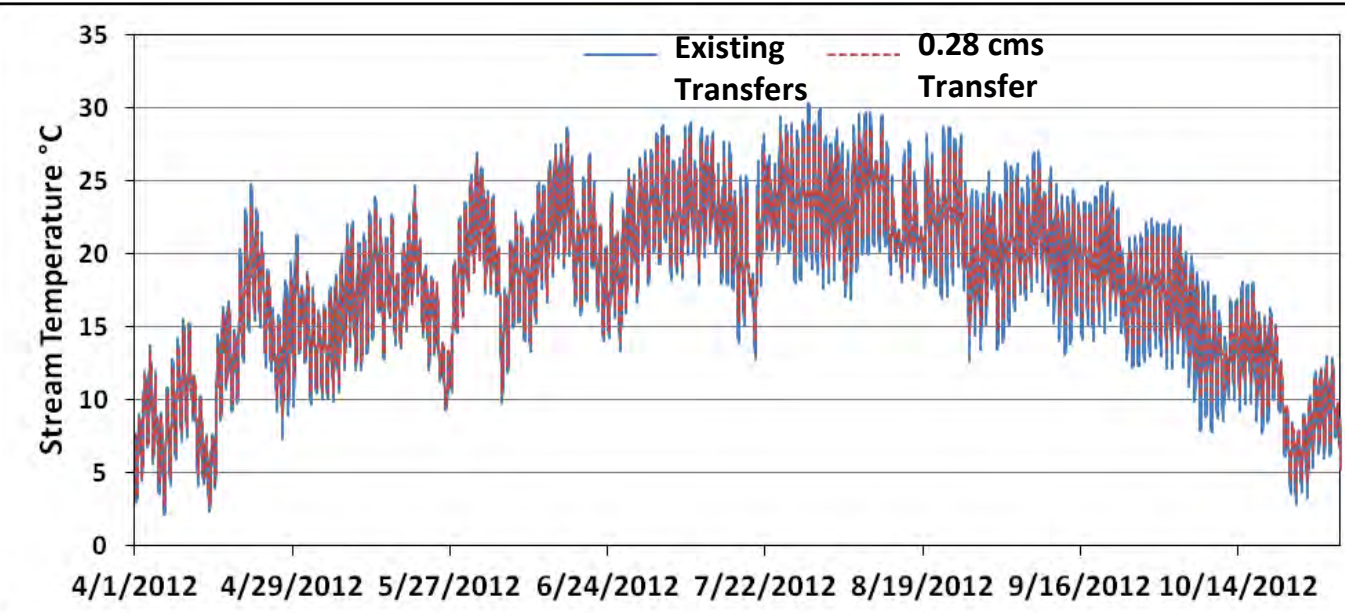

Figure B-53: Existing transfers versus $0.28 \mathrm{cms}$ transfers from Bridgeport Reservoir stream temperatures at RKM 2.69 near the mouth of Walker Lake.

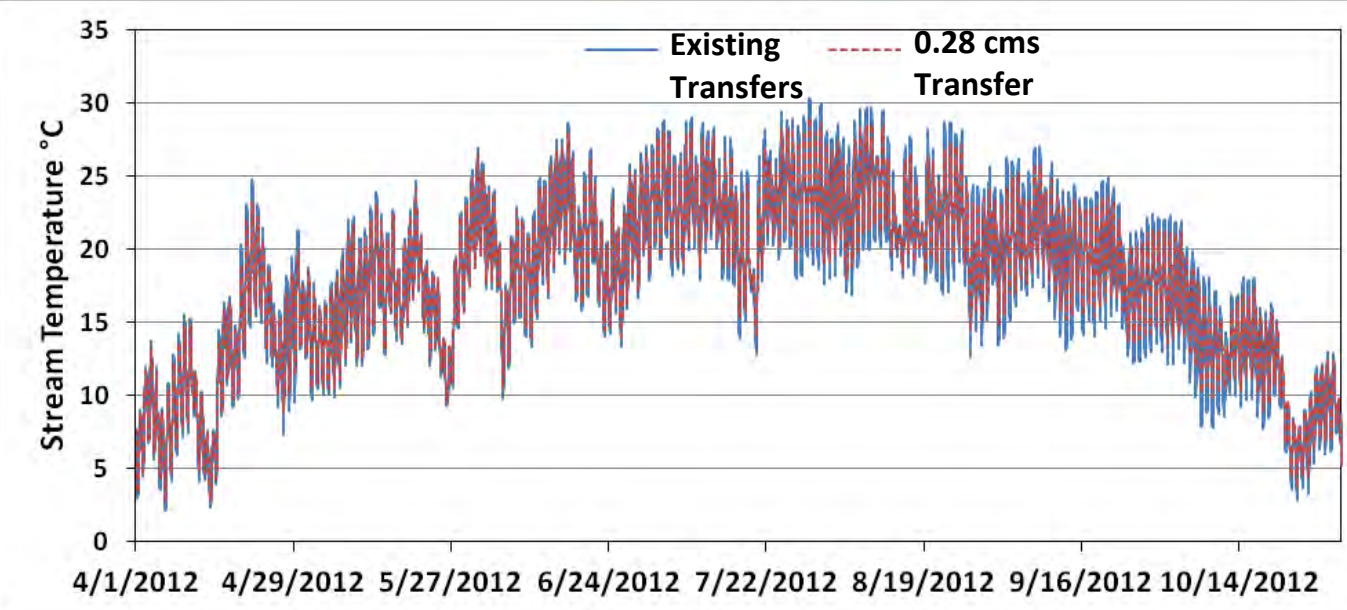

Figure B-54: Existing transfers versus $0.28 \mathrm{cms}$ transfers from BNGHH diversion stream temperatures at RKM 2.69 near the mouth of Walker Lake 


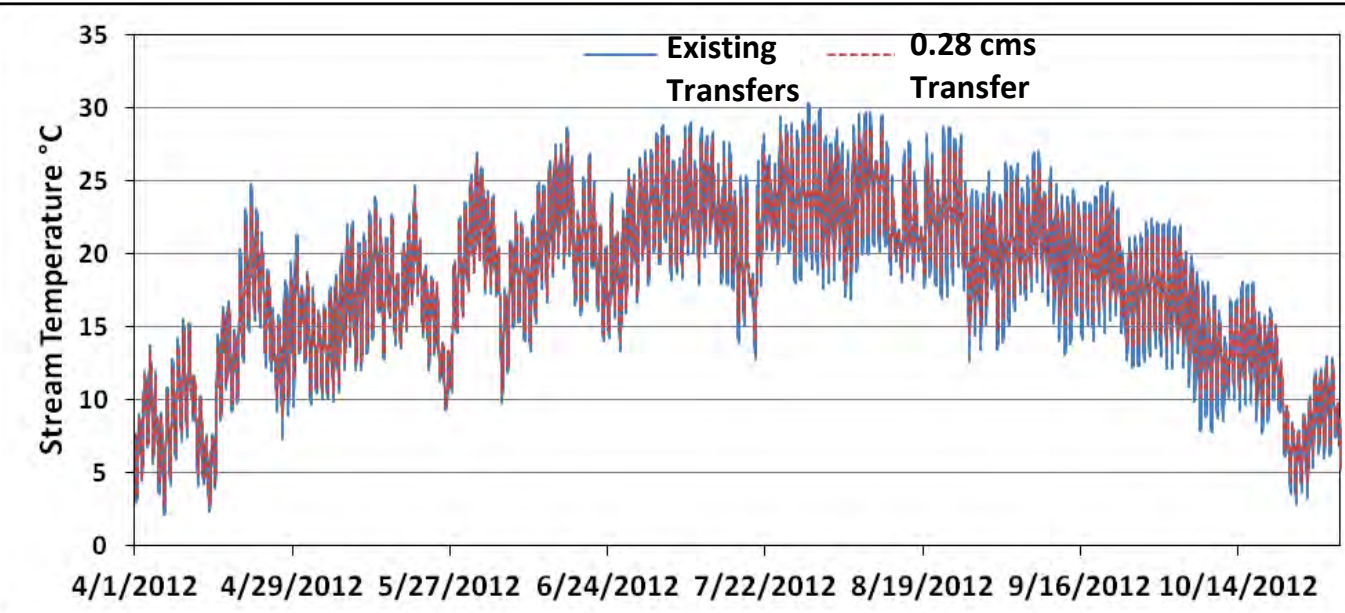

Figure B-55: Existing transfers versus $0.28 \mathrm{cms}$ transfers from FOX diversion stream temperatures at RKM 2.69 near the mouth of Walker Lake

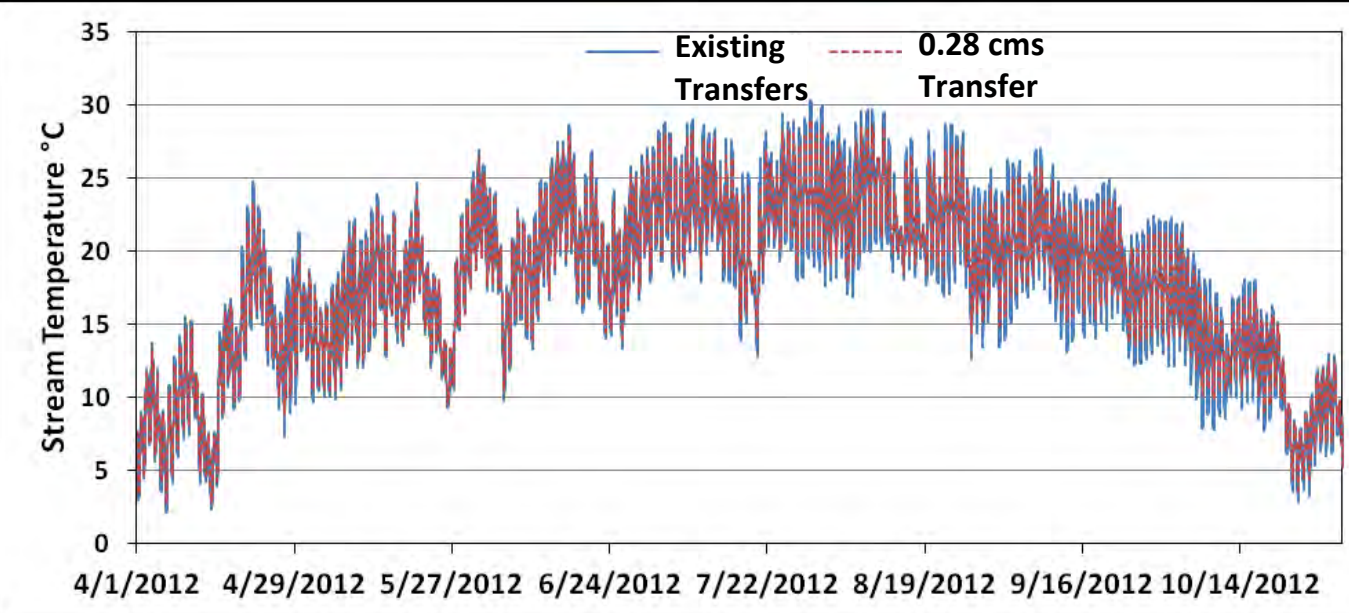

Figure B-56: Existing transfers versus $0.28 \mathrm{cms}$ transfers from MCCAMP diversion stream temperatures at RKM 2.69 near the mouth of Walker Lake 


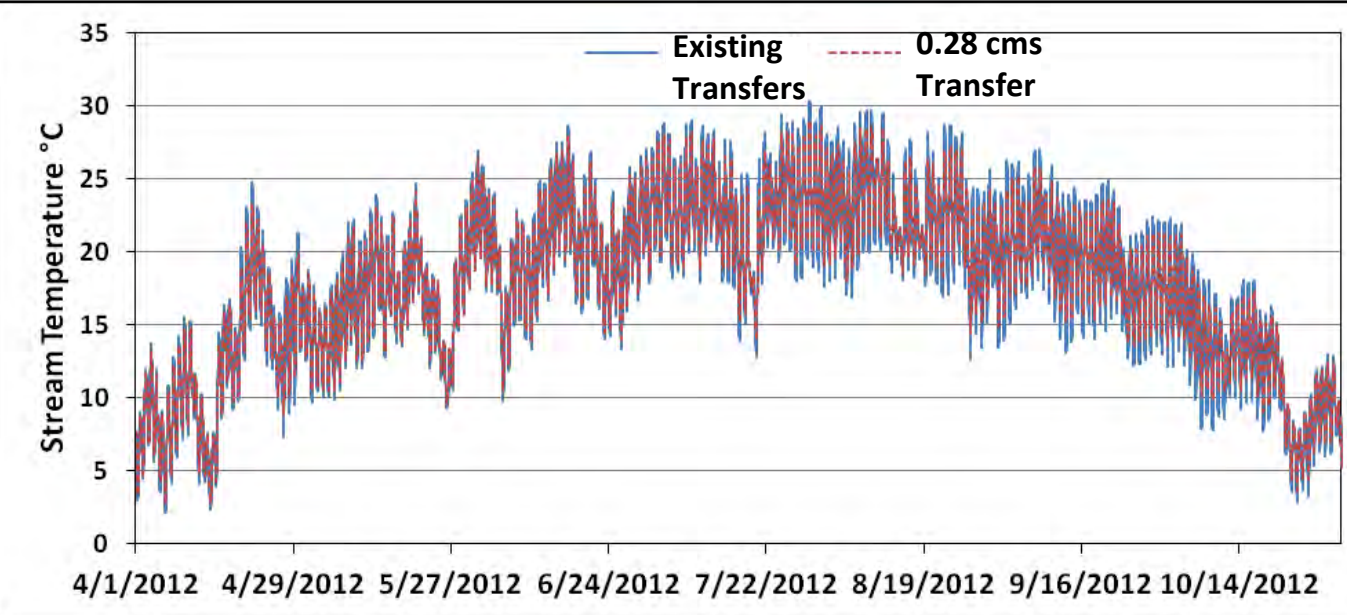

Figure B-57: Existing transfers versus $0.28 \mathrm{cms}$ transfers from SSWJD diversion stream temperatures at RKM 2.69 near the mouth of Walker Lake

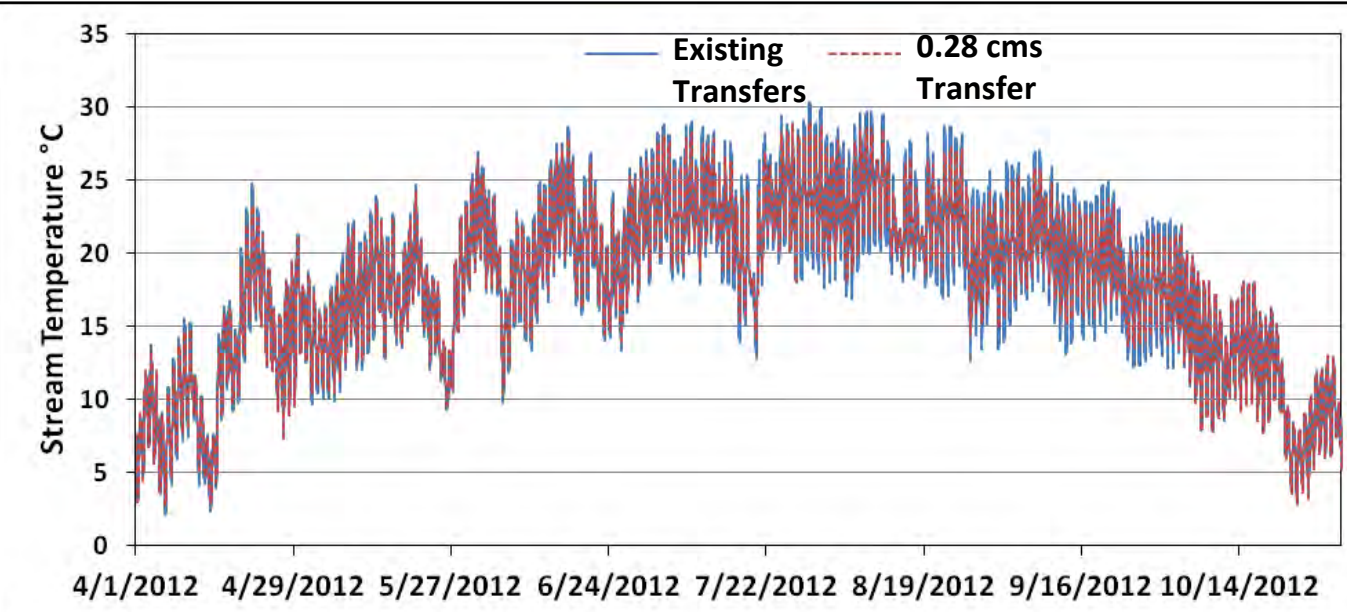

Figure B-58: Existing transfers versus $0.28 \mathrm{cms}$ transfers from CANAL diversion stream temperatures at RKM 2.69 near the mouth of Walker Lake 


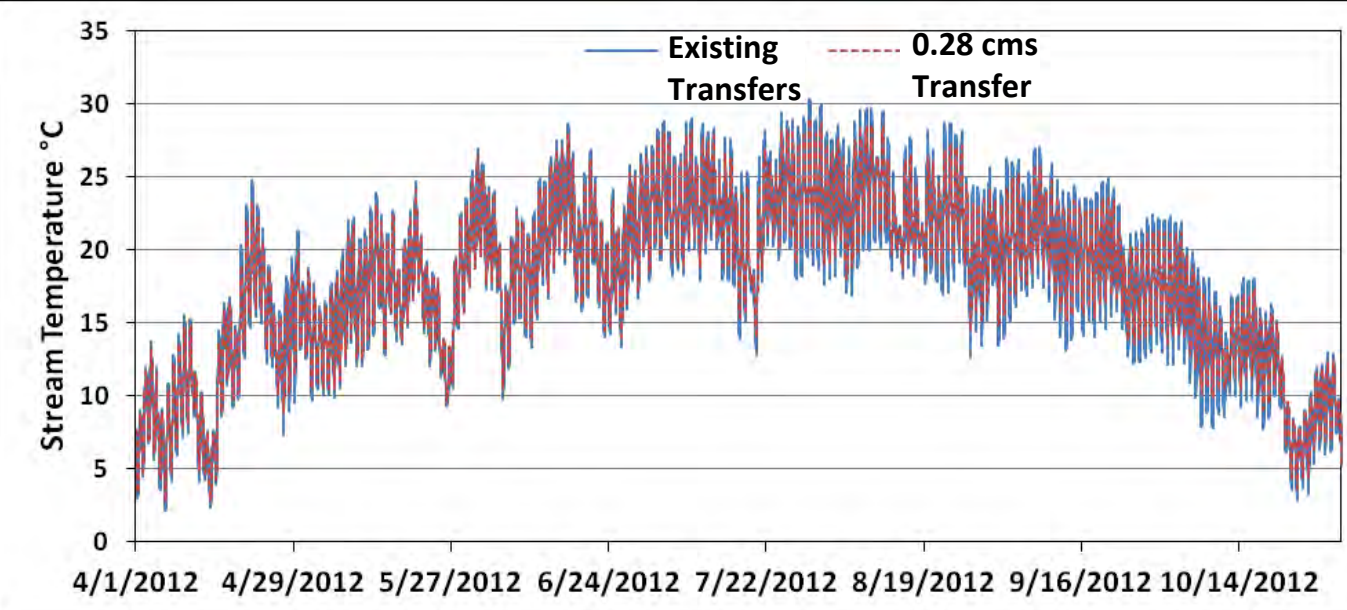

Figure B-59: Existing transfers versus $0.28 \mathrm{cms}$ transfers from SARONI diversion stream temperatures at RKM 2.69 near the mouth of Walker Lake

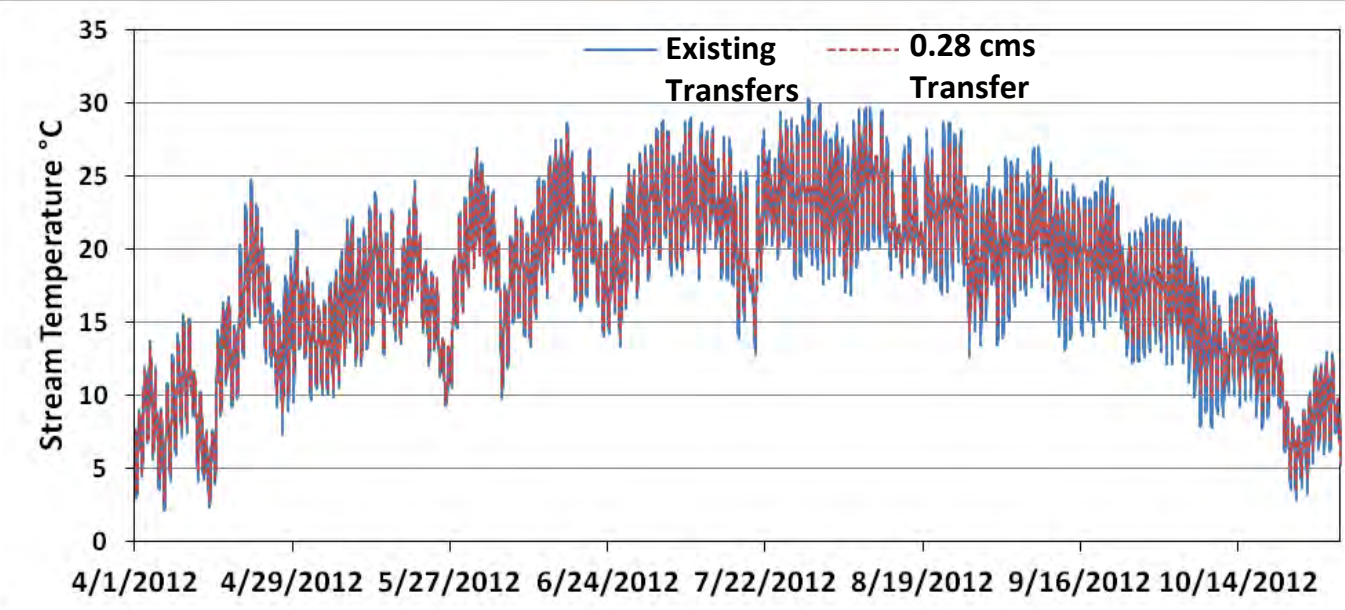

Figure B-60: Existing transfers versus $0.28 \mathrm{cms}$ transfers from CANAL diversion stream temperatures at RKM 2.69 near the mouth of Walker Lake 


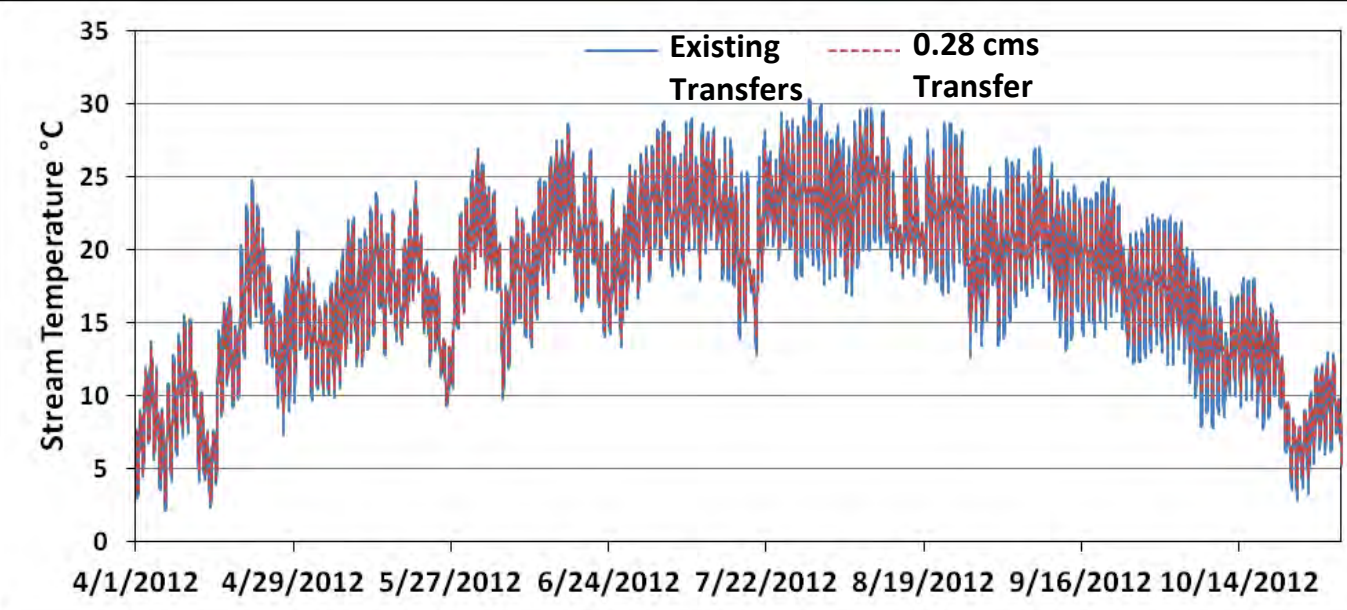

Figure B-61: Existing transfers versus $0.28 \mathrm{cms}$ transfers from COLONY diversion stream temperatures at RKM 2.69 near the mouth of Walker Lake

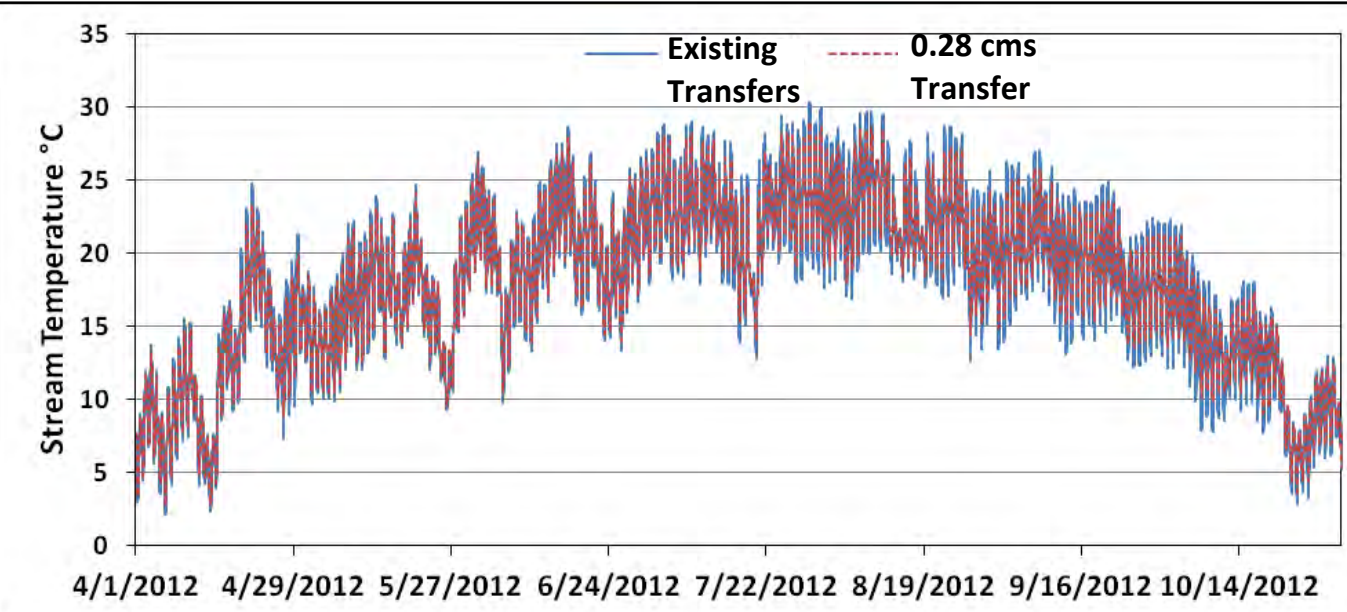

Figure B-62: Existing transfers versus $0.28 \mathrm{cms}$ transfers from TUNNEL diversion stream temperatures at RKM 2.69 near the mouth of Walker Lake 


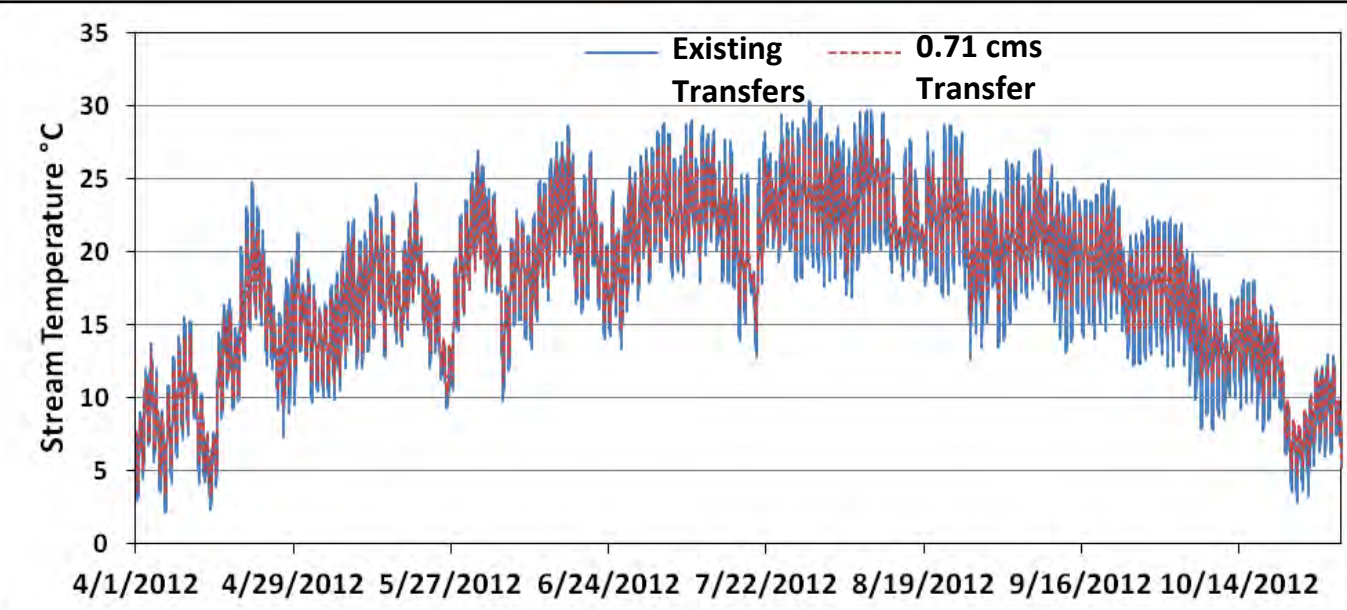

Figure B-63: Existing transfers versus $0.71 \mathrm{cms}$ transfers from Bridgeport Reservoir stream temperatures at RKM 2.69 near the mouth of Walker Lake

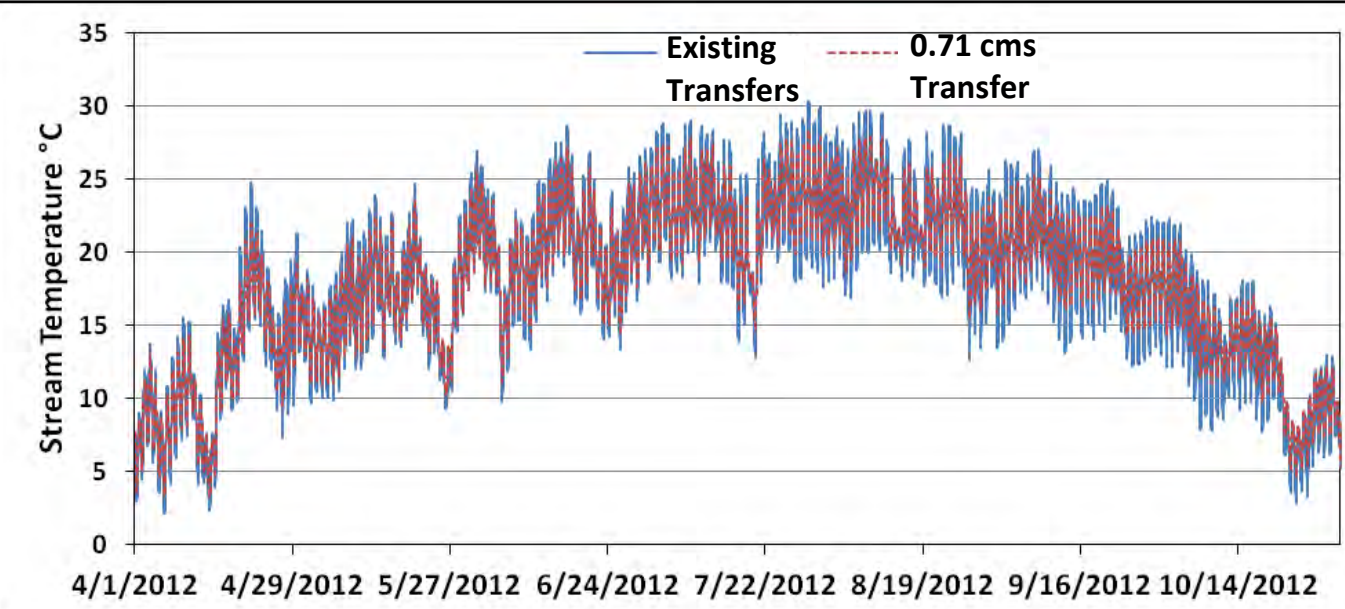

Figure B-64: Existing transfers versus $0.71 \mathrm{cms}$ transfers from Topaz Reservoir stream temperatures at RKM 2.69 near the mouth of Walker Lake 


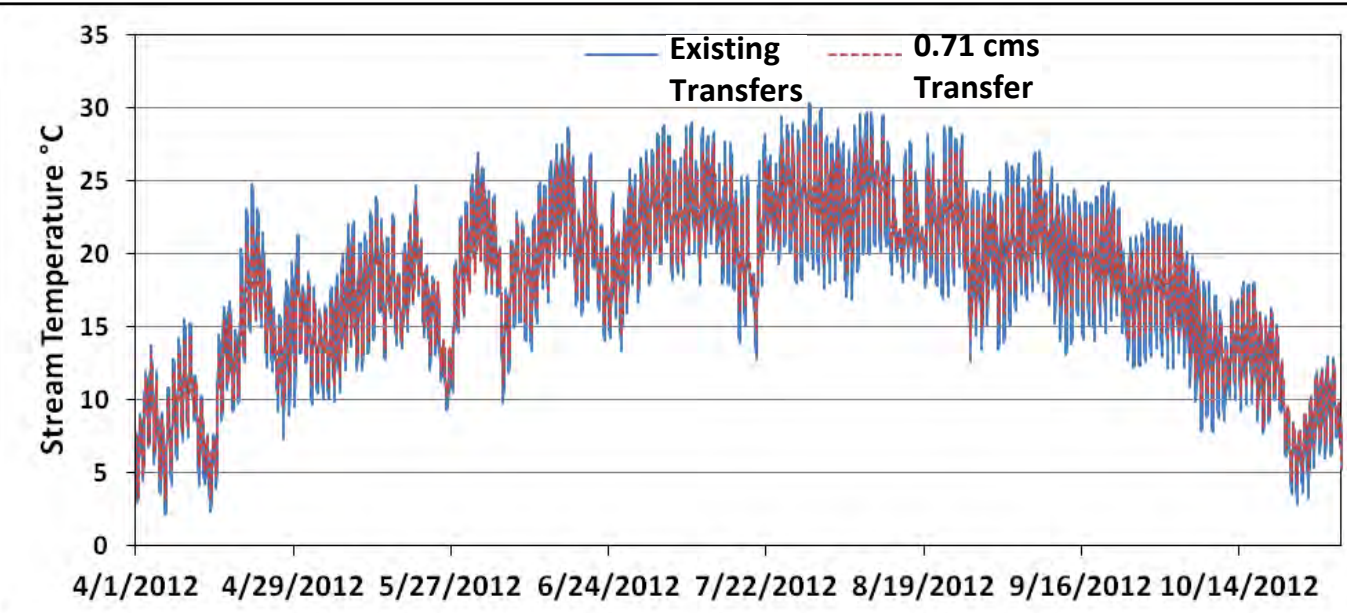

Figure B-65: Existing transfers versus $0.71 \mathrm{cms}$ transfers from SSWJD diversion stream temperatures at RKM 2.69 near the mouth of Walker Lake

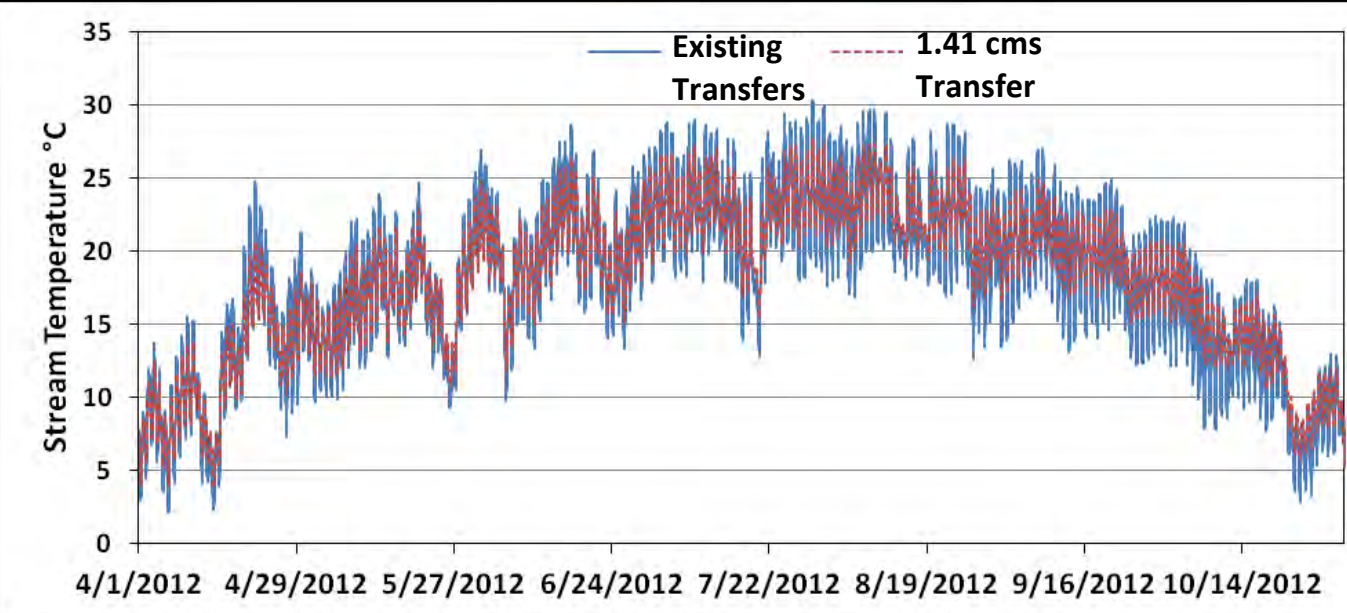

Figure B-66: Existing transfers versus $1.41 \mathrm{cms}$ transfers from Bridgeport Reservoir stream temperatures at RKM 2.69 near the mouth of Walker Lake 


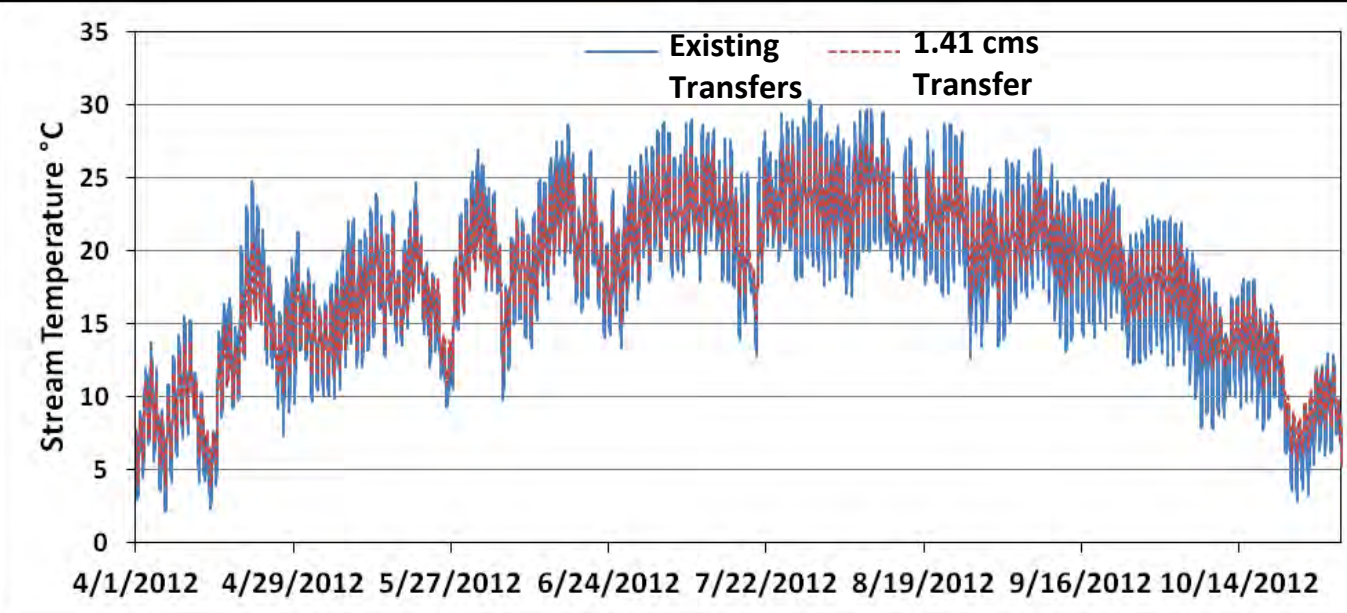

Figure B-67: Existing transfers versus $1.41 \mathrm{cms}$ transfers from Topaz Reservoir stream temperatures at RKM 2.69 near the mouth of Walker Lake.

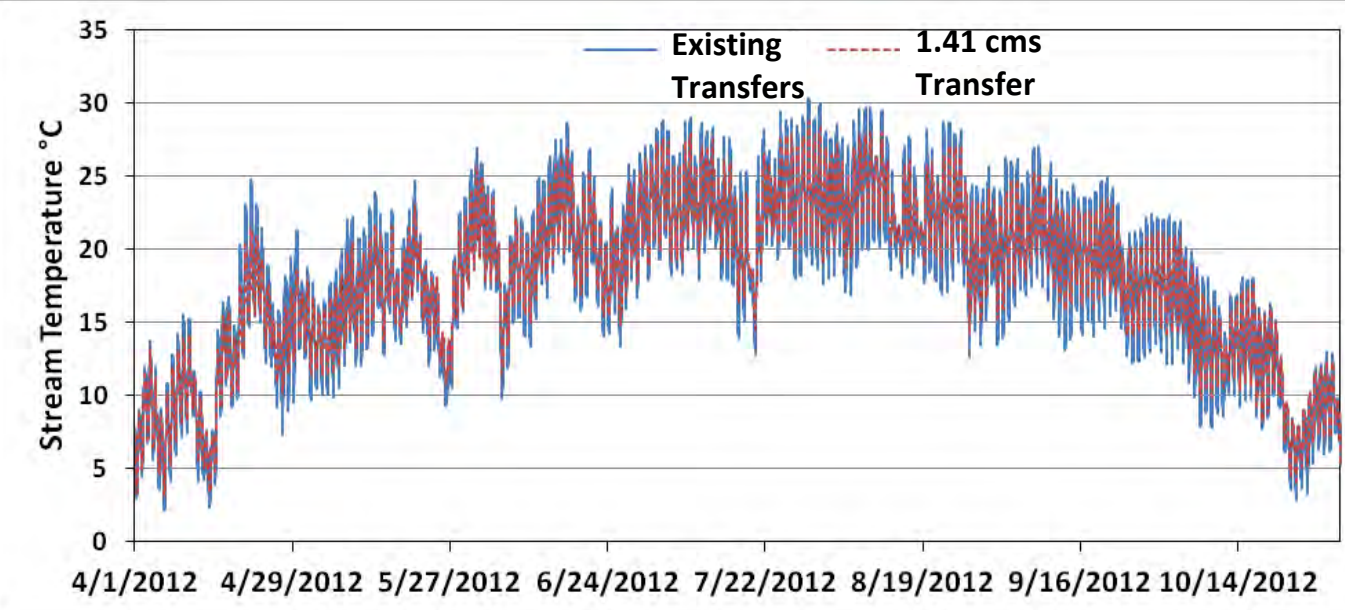

Figure B-68: Existing transfers versus $1.41 \mathrm{cms}$ transfers from SSWJD diversion stream temperatures at RKM 2.69 near the mouth of Walker Lake 
Zero Diversion Scenarios: all diversions during the irrigation season turned off, singly, for each diversion.

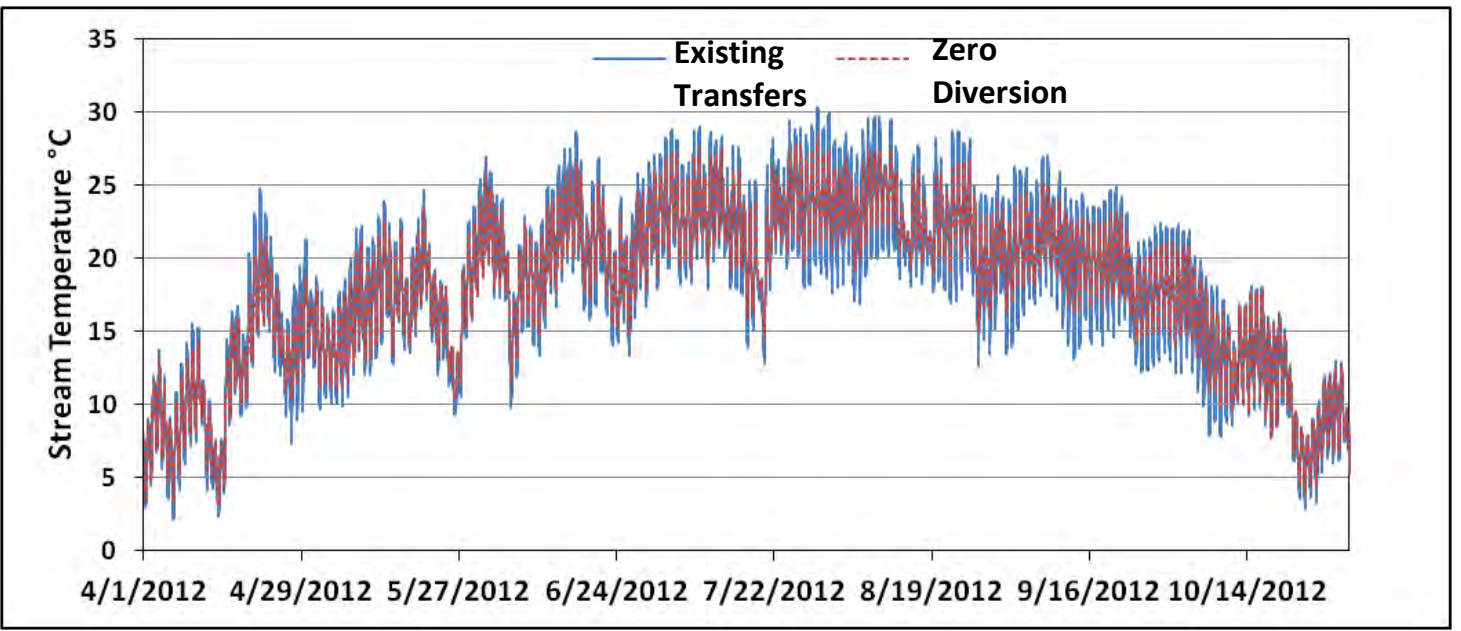

Figure B-69: Existing transfers versus zero diversions from BNGHH diversion stream temperatures at RKM 2.69 near the mouth of Walker Lake.

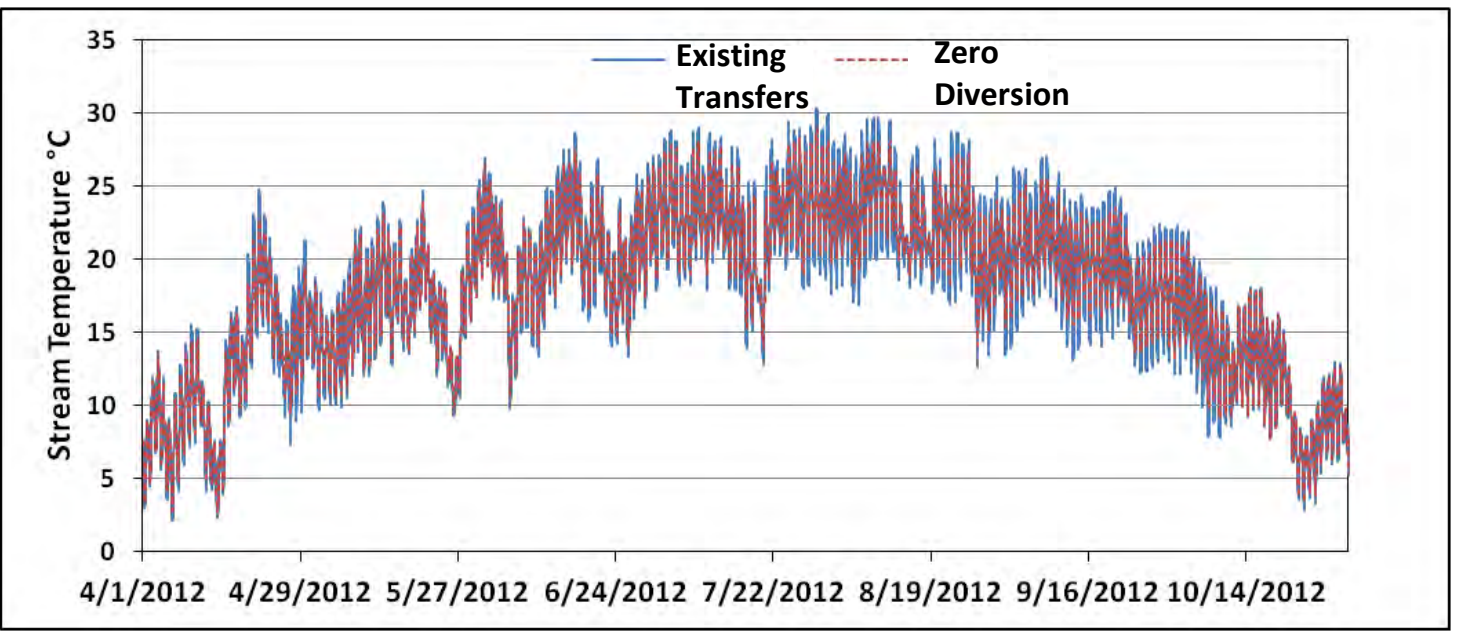

Figure B-70: Existing transfers versus zero diversions from FOX diversion stream temperatures at RKM 2.69 near the mouth of Walker Lake. 


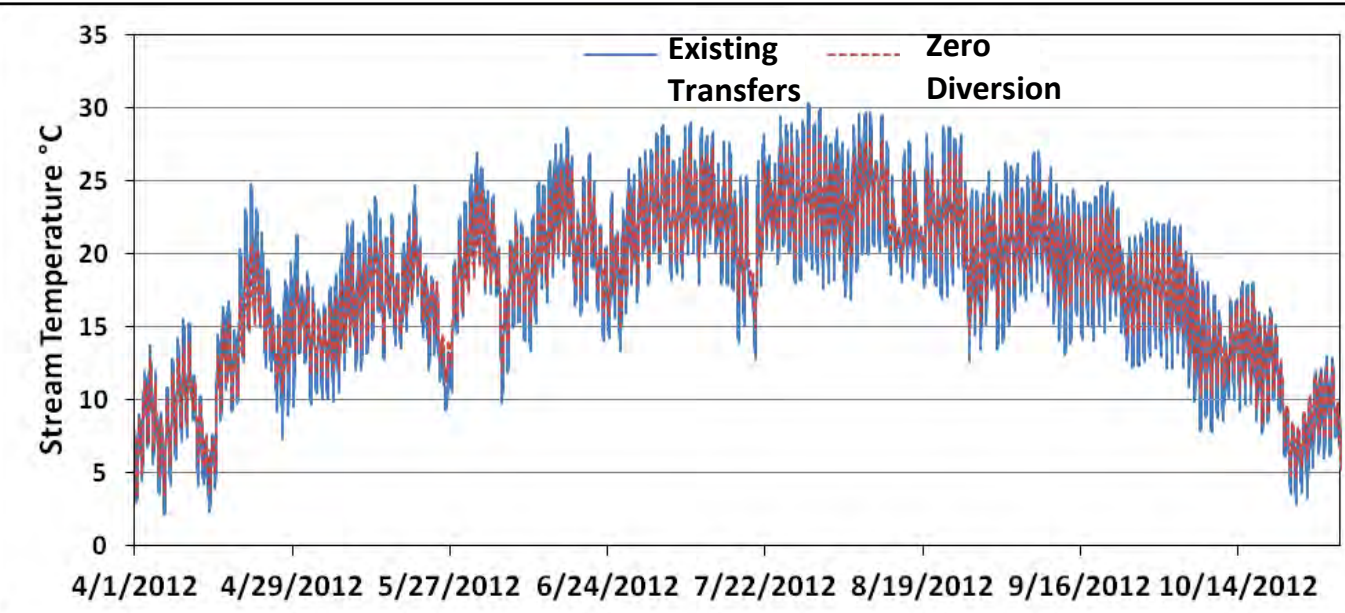

Figure B-71: Existing transfers versus zero diversions from MCCAMP diversion stream temperatures at RKM 2.69 near the mouth of Walker Lake.

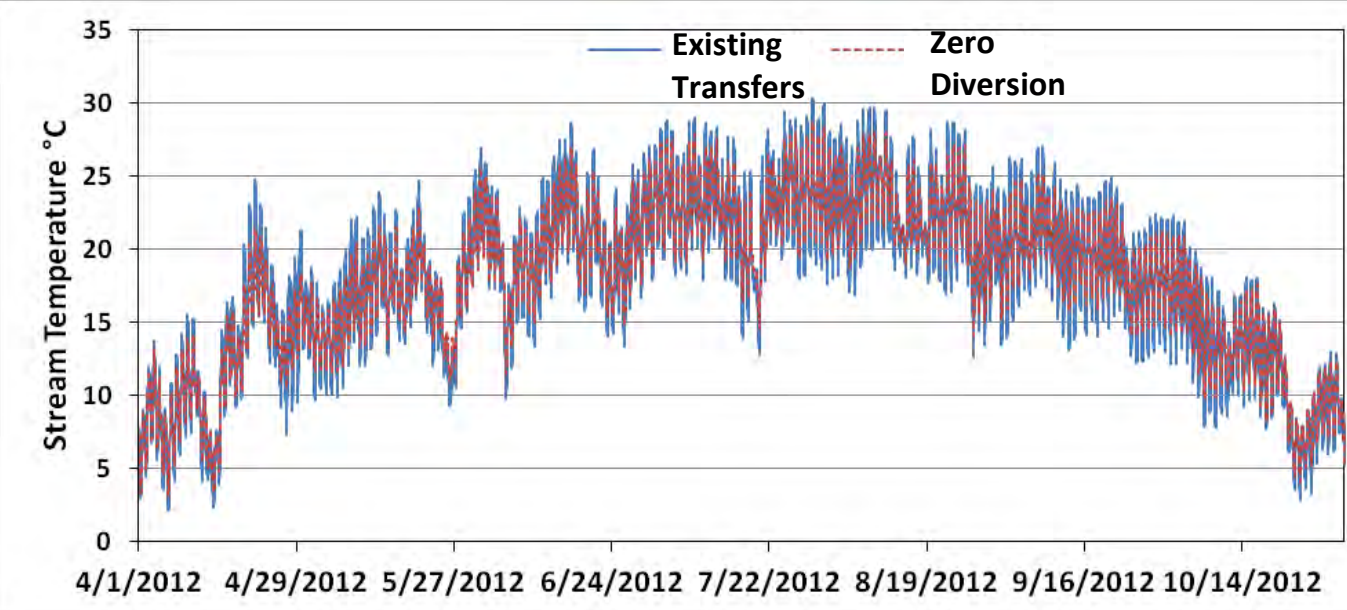

Figure B-72: Existing transfers versus zero diversions from SSWJD diversion stream temperatures at RKM 2.69 near the mouth of Walker Lake. 


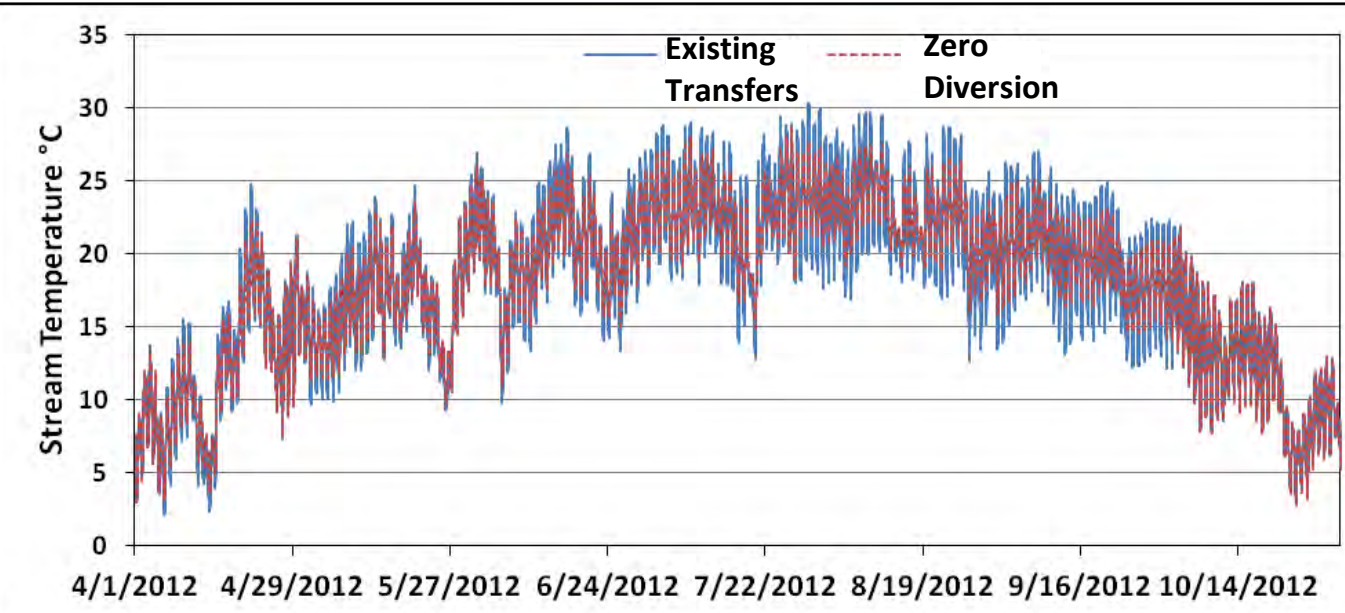

Figure B-73: Existing transfers versus zero diversions from CANAL diversion stream temperatures at RKM 2.69 near the mouth of Walker Lake.

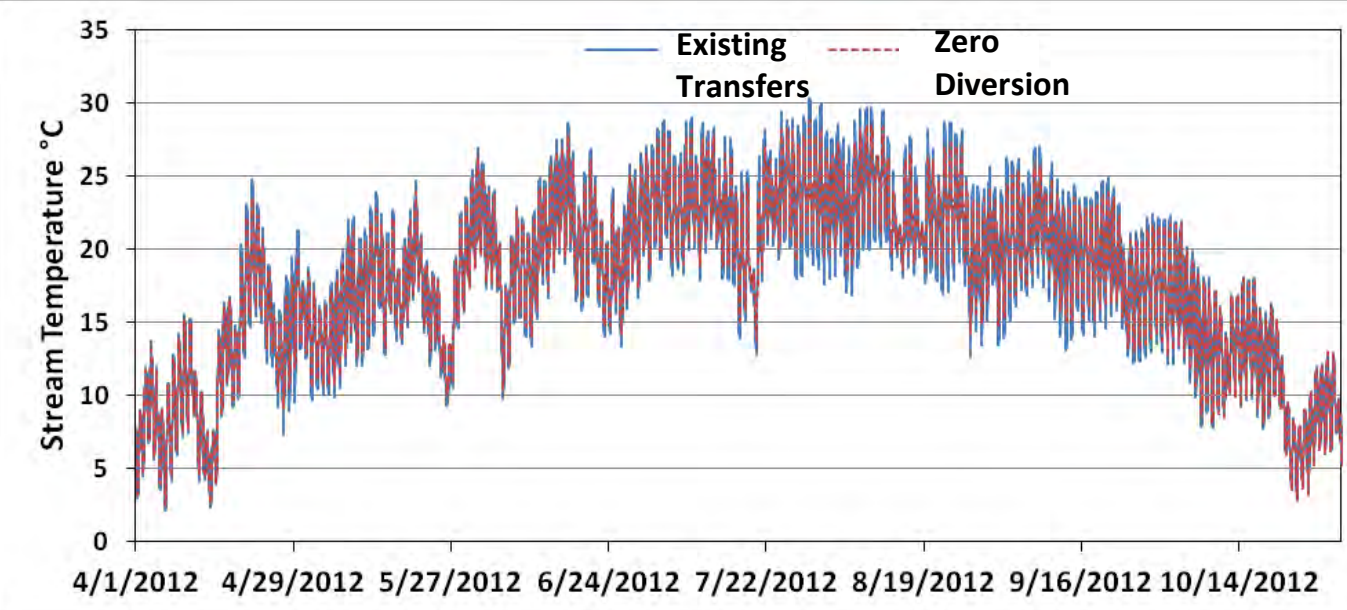

Figure B-74: Existing transfers versus zero diversions from SARONI diversion stream temperatures at RKM 2.69 near the mouth of Walker Lake. 


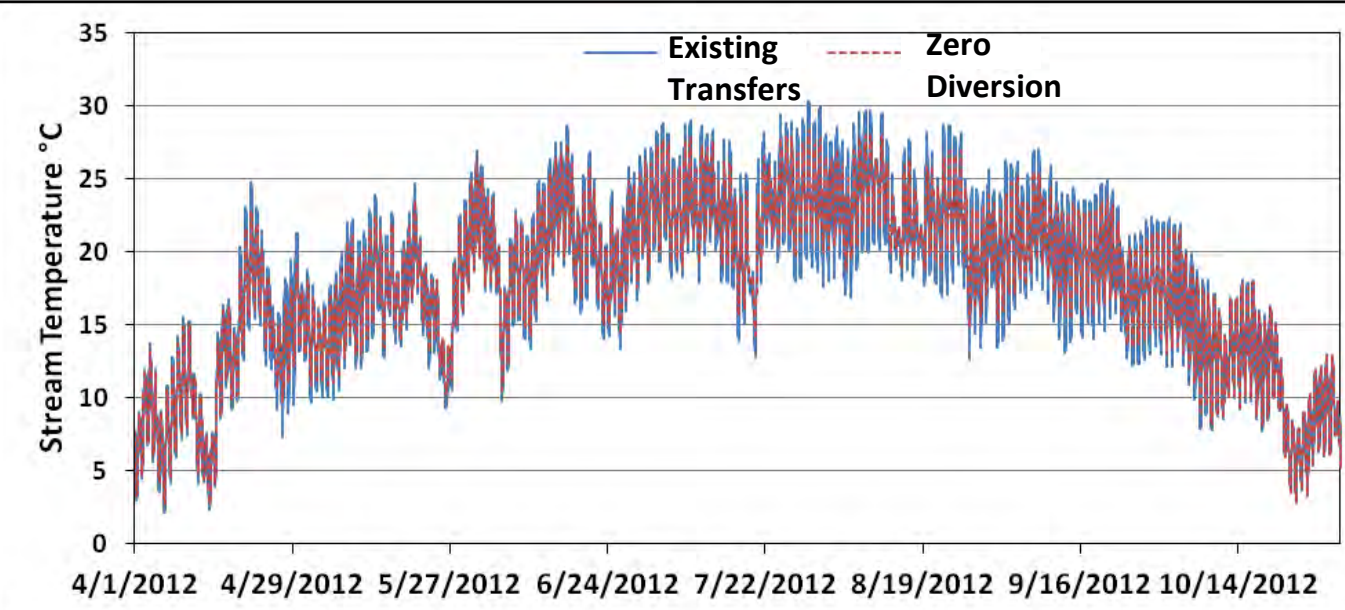

Figure B-75: Existing transfers versus zero diversions from GAGE diversion stream temperatures at RKM 2.69 near the mouth of Walker Lake.

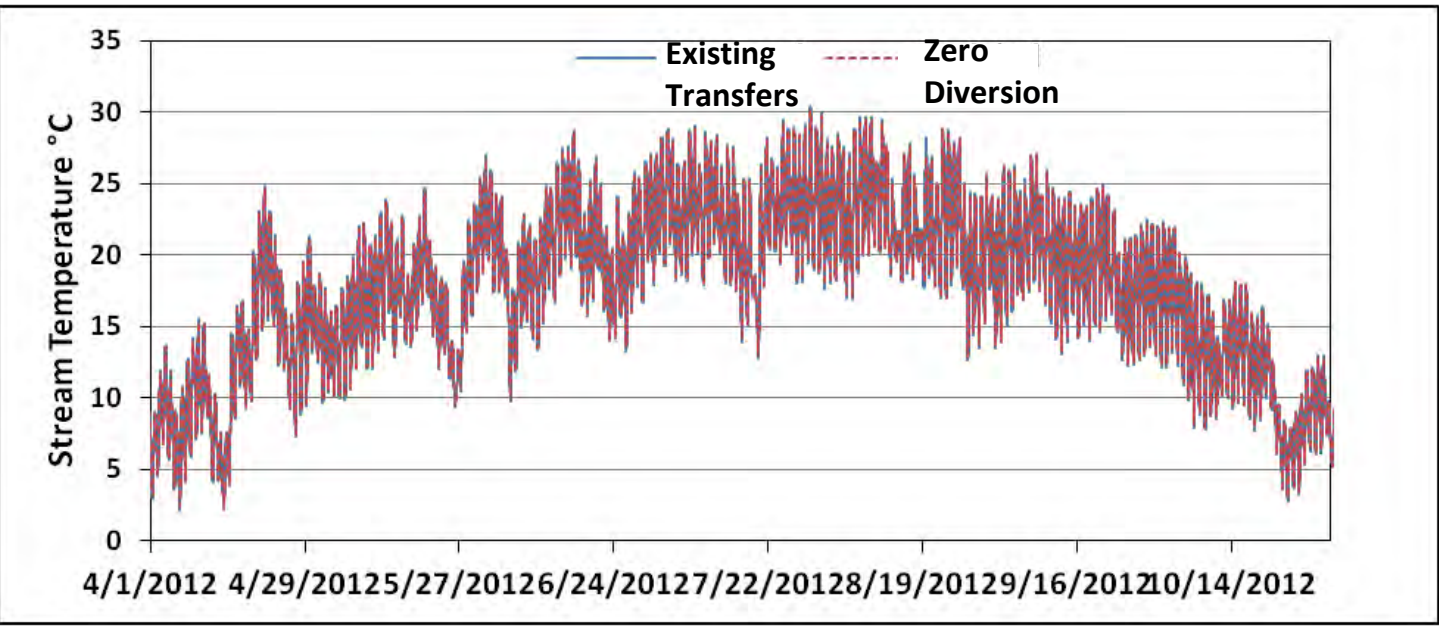

Figure B-76: Existing transfers versus zero diversions from COLONY diversion stream temperatures at RKM 2.69 near the mouth of Walker Lake. 


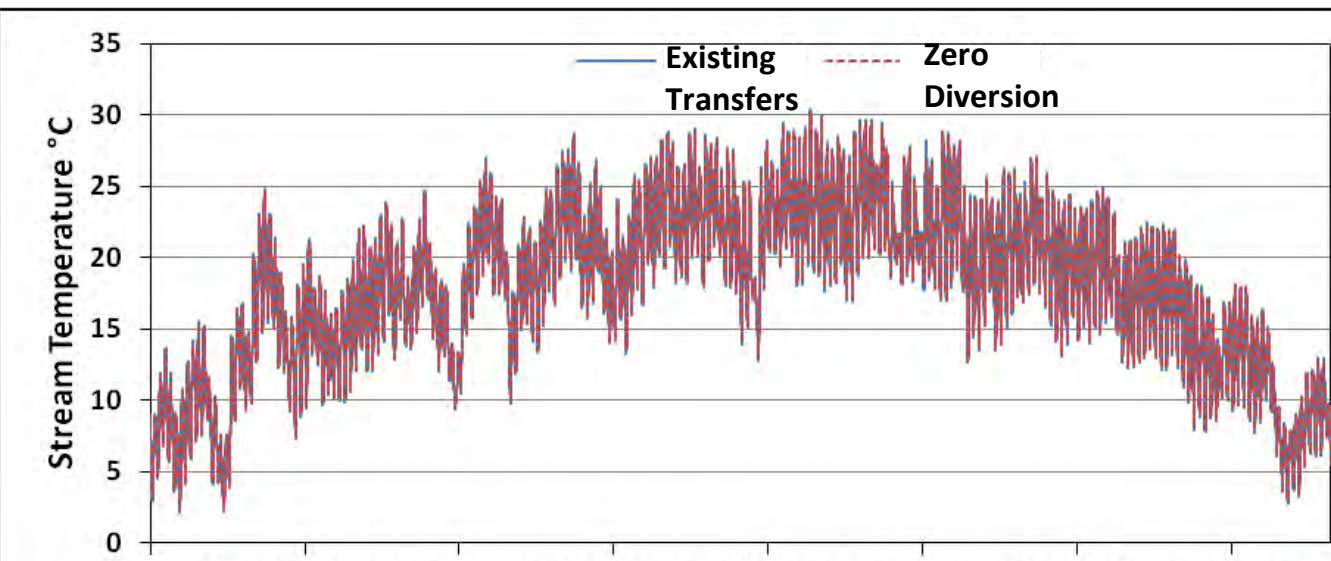

$4 / 1 / 20124 / 29 / 20125 / 27 / 20126 / 24 / 20127 / 22 / 20128 / 19 / 20129 / 16 / 20120 / 14 / 2012$

Figure B-77: Existing transfers versus zero diversions from TUNNEL diversion stream temperatures at RKM 2.69 near the mouth of Walker Lake.

No Diversion Scenario: All diversions turned off for all diversions combined in one run.

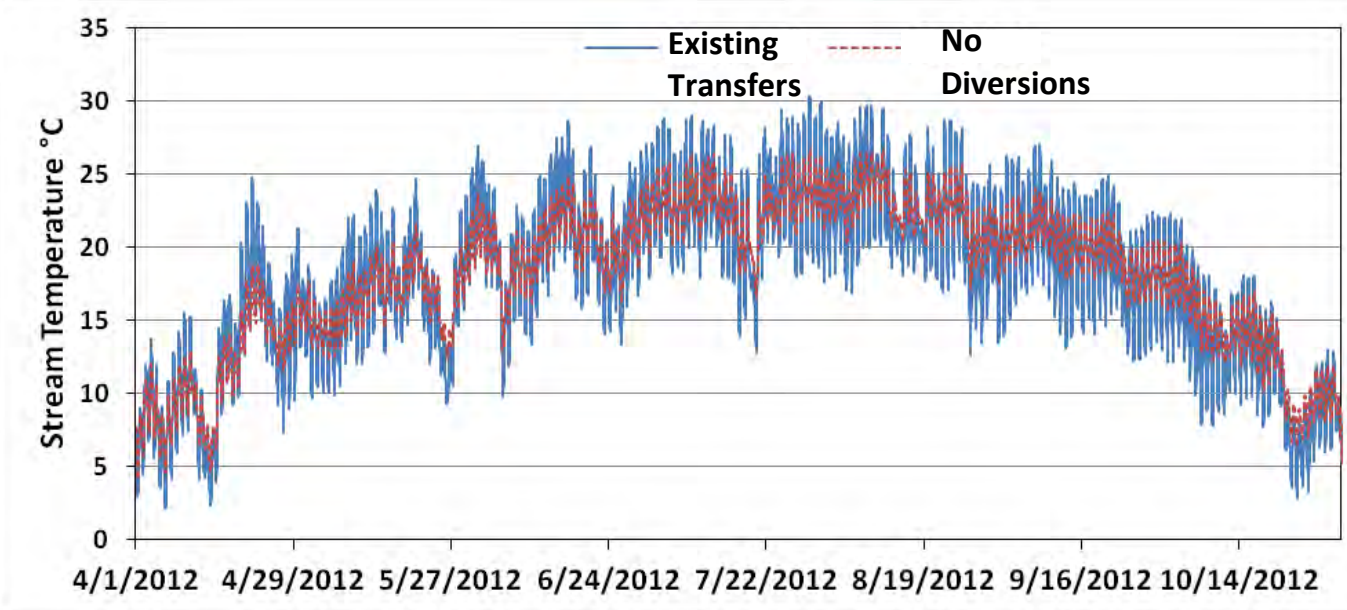

Figure B-78: Existing transfers versus no diversions at all diversions (combined) stream temperatures at RKM 2.69 near the mouth of Walker Lake. 
Sensitivity Analyses:

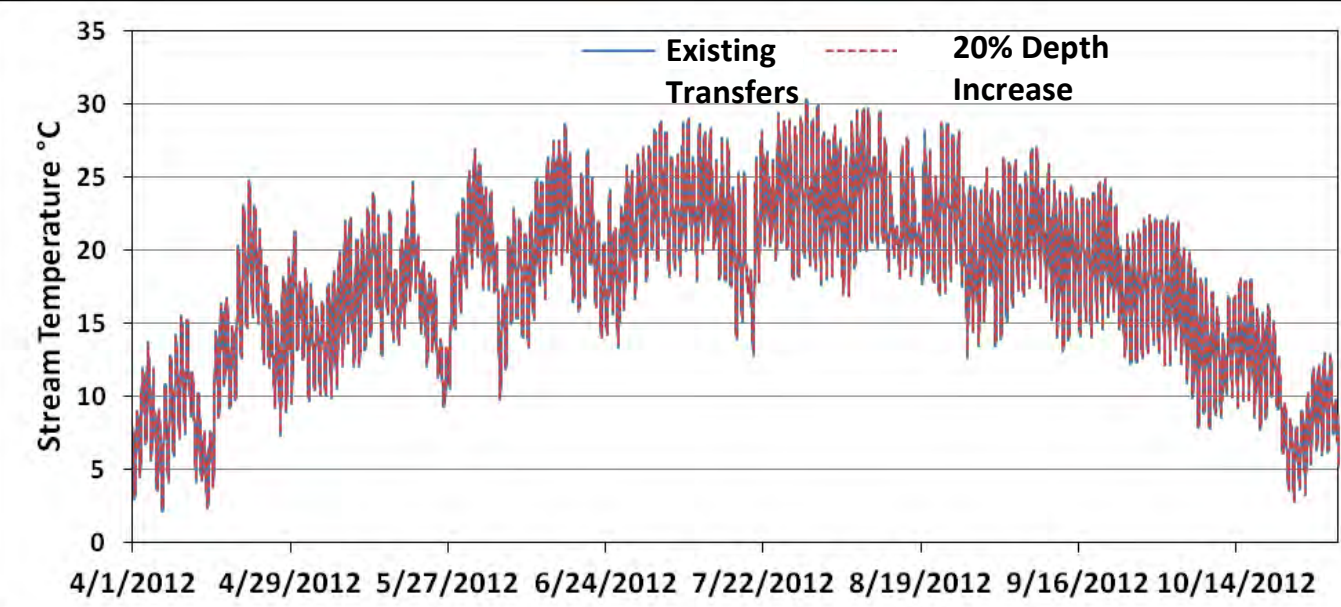

Figure B-79: Sensitivity analysis of Existing transfers with $0.94 \mathrm{~m}$ depth versus Existing transfers with $1.18 \mathrm{~m}$ depth ( $20 \%$ increase) stream temperatures at RKM 2.69 near the mouth of Walker Lake.

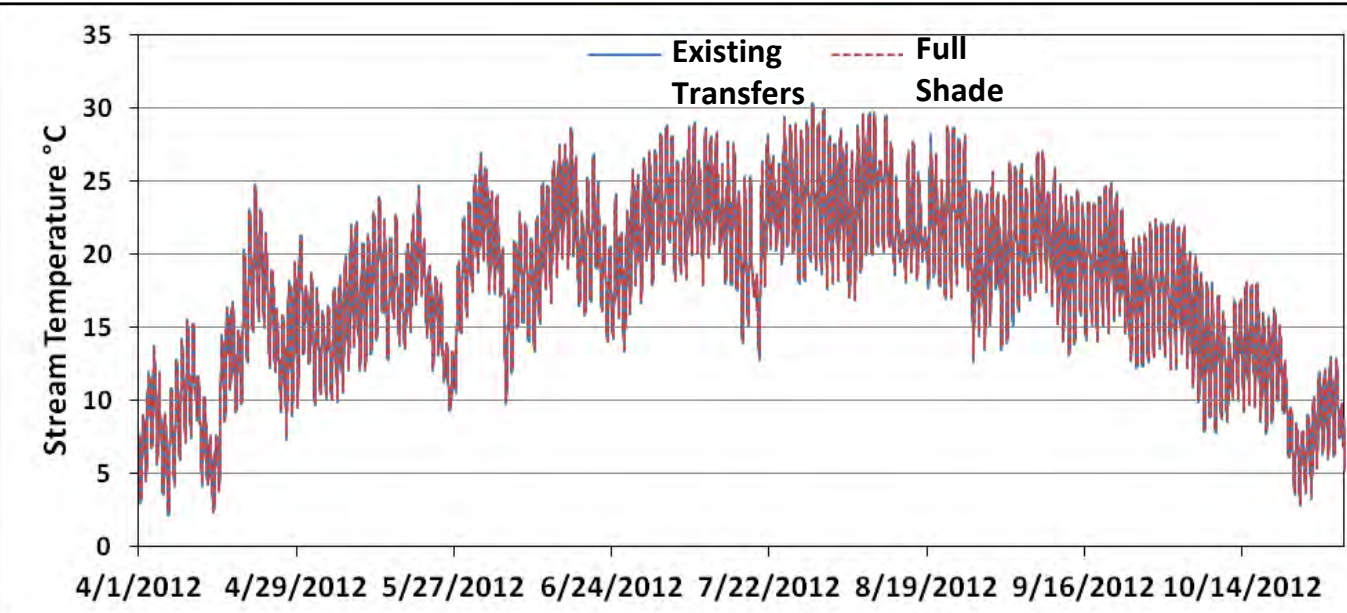

Figure B-80: Sensitivity analysis of Existing transfers scenario versus Existing transfers with full shade stream temperatures at RKM 2.69 near the mouth of Walker Lake. 